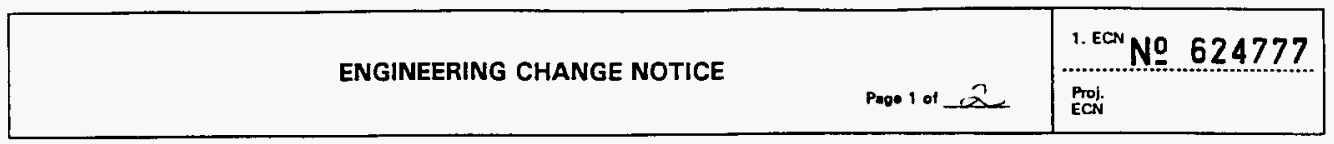

\begin{tabular}{|c|c|c|c|c|c|c|}
\hline \multirow{3}{*}{$\begin{array}{l}\text { 2. ECN Category } \\
\text { (mark one) } \\
\text { Suppl emental } \\
\text { Direct Revision } \\
\text { Change ECN } \\
\text { Iemporary } \\
\text { Standby } \\
\text { Supersedure } \\
\text { Cancel/Void }\end{array}$} & \multirow{3}{*}{$\begin{array}{r}{[]} \\
{[X]} \\
{[]} \\
{[]} \\
{[]} \\
{[]} \\
{[]}\end{array}$} & \multicolumn{2}{|c|}{$\begin{array}{l}\text { 3. Originator's Name, Organization, MSIN, } \\
\text { and Telephone No. } \\
\text { Norman Scott Cannon, } 8 A 200 \\
\text { L6-38, 376-0562 }\end{array}$} & \multicolumn{2}{|c|}{$\begin{array}{l}\text { 3a. USO Required? } \\
{[] \text { Yes }[X] \text { No }}\end{array}$} & $\begin{array}{l}\text { 4. Date } \\
06 / 24 / 96\end{array}$ \\
\hline & & \multicolumn{2}{|c|}{$\begin{array}{l}\text { 5. Project Title/No./Work Order No. } \\
\text { Retained Gas Sampler System } \\
\text { Acceptance Test Report/N2155 }\end{array}$} & \multicolumn{2}{|c|}{$\begin{array}{l}\text { 6. Bldg./Sys./Fac. No. } \\
\text { 200-G }\end{array}$} & $\begin{array}{c}\text { 7. Approval Designator } \\
Q\end{array}$ \\
\hline & & \multicolumn{2}{|c|}{$\begin{array}{l}\text { 8. Document Numbers Changed by this ECN } \\
\text { (includes sheet no. and rev.) } \\
\text { WHC-SD-WM-ATR-137, Rev. } 0\end{array}$} & \multicolumn{2}{|c|}{$\begin{array}{l}\text { 9. Related ECN No(s). } \\
\qquad N / A\end{array}$} & 10. Related PO No. \\
\hline \multicolumn{2}{|c|}{$\begin{array}{l}\text { 11a. Modification Work } \\
\text { [] Yes (fill out } 81 k \text {. } \\
\text { llb) } \\
{[X] \text { No (NA Blks. 11b, }} \\
11 \mathrm{c}, 11 \mathrm{~d})\end{array}$} & $\begin{array}{l}\text { 11b. Work Package } \\
\text { No. } \\
\text { N } / A\end{array}$ & \multicolumn{2}{|c|}{$\begin{array}{l}\text { 11c. Modification Work Complete } \\
\qquad \mathrm{N} / \mathrm{A} \\
\text { Cog. Engineer signature \& Date }\end{array}$} & \multicolumn{2}{|c|}{$\begin{array}{l}\text { 11d. Restored to Original Condi- } \\
\text { tion (Temp. or Standby ECN only) } \\
\qquad N / A \\
\text { Cog. Engineer signature \& Date }\end{array}$} \\
\hline
\end{tabular}

12. Description of Change

The document WHC-SD-WM-ATP-137, Rev. 0 was revised to produce WHC-SD-WM-ATP-137, Rev. 1. Major changes resulting from the revision was the inclusion of an additional long term sampler aging test finished after the original document was complete; also the original Appendix F (Two Volume Method Ammonia Vapor Pressure Approximation) was changed to Appendix $G$, and a new Appendix $F$ created dealing with hydrogen seal penetration.

13a. Just ification (mark one)

Criteria Change [] Design Improvement

As-found [] Facilitate const [X]

[] Environmental [] Facility Deactivation [X] Const. Error/Omission Design Error/Onission

13b. Justification Details

This revision adds addition sampler aging test data analysis and conclusions not available at the time the original document was completed due to the necessary long term nature of the test.

14. Distribution (include name, MSIN, and no. of copies)

Norman Scott Cannon, L6-38 (5)

Ronald Craig Knight, L6-38 (3)

See attached Distribution Sheet 


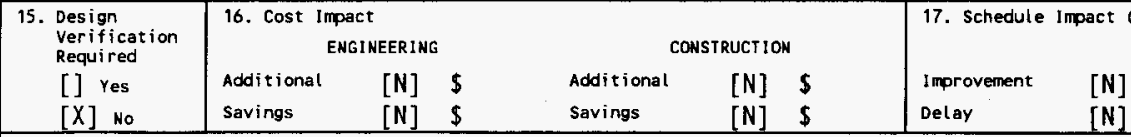

18. Change Impact Review: Indicate the related documents (other than the engineering documents ident ified on side 1 ) that will be affected by the change described in Block 12 . Enter the affected document number in Block 19.

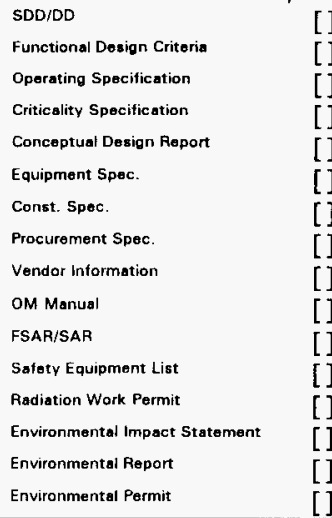

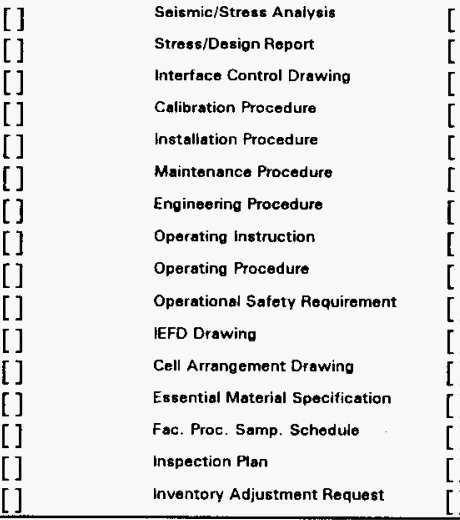

$\begin{array}{ll}\text { [] } & \text { Tank Calibration Manual } \\ {[]} & \text { Health Physics Procedure } \\ {[]} & \text { Spares Muttiple Unit Listing } \\ {[]} & \text { Test Procedures/Specificatio } \\ {[]} & \text { Component Index } \\ {[]} & \text { ASME Coded Item } \\ {[]} & \text { Human Foctor Consideration } \\ {[]} & \text { Computer Software } \\ {[]} & \text { Electric Circuit Schedule } \\ {[]} & \text { ICRS Procedure } \\ {[]} & \text { Process Control Manual/Plen } \\ {[]} & \text { Process Flow Chart } \\ {[]} & \text { Purchase Requisition } \\ {[]} & \text { Tickler File } \\ {[]} & \\ {[]} & \end{array}$

19. Other Affected Documents: (NOTE: Documents listed below will not be revised by this ECN.) Signatures below indicate that the signing organization has been notified of other affected documents listed below. Document Number/Revision Document Number/Revision Document Number Revision

WHC-SD-WM-ATR-137

Revision 0

20. Approvals

\section{Signature OPERATIONS AND ENGINEERING}

Cog. Eng. N. S. Cannon $N$ \& Canner cog. Mgr. J. R. Thielges fRThilges oA B. J. Hug B.Q. $310 \mathrm{~kg}$

Safety $\mathrm{C}^{2-2}$

Environ.

Other R. C. Knight R. E. Baver

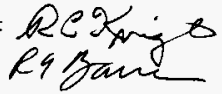

Date
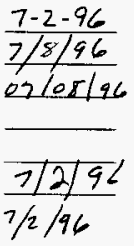

\section{ARCHITECT -ENGINEER}

PE

QA

Safety

Design

Environ.

other

\section{DEPARTMENT OF ENERGY}

Signature or a Control Number that

tracks the Approval Signature

AOOITIONAL 


\title{
RETAINED GAS SAMPLER SYSTEM ACCEPTANCE TEST REPORT
}

\author{
N. S. Cannon \\ Westinghouse Hanford, Richland, WA 99352 \\ U.S. Department of Energy Contract DE-AC06-87RL10930

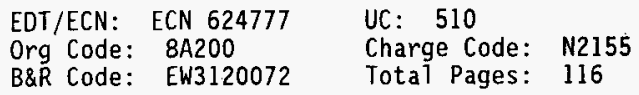

Key Words: Retained Gas Sampler, Extractor, Extruder, Gas Chromatograph, Calibration, Spectrometer, Pressure Transducer, Thermocouple

Abstract: Acceptance test results for the Retained Gas Sampler System (RGSS) obtained in the 306E laboratory are reported. The RGSS will be utilized to retrieve and analyze samples from the Hanford flammable gas watch-1ist tanks to determine the quantity and chemistry of gases confined within the waste.

TRADEMARK DISCLAIMER, Reference herein to any specific commercial product, process, or service by trade name, trademark, manufacture $r$, or otherwise, does not necessarily constitute or imply its endorsement, recommendation, or favoring by the United States Government or any agency thereof or its contractors or subcontractors.

Printed in the United States of America. To obtain copies of this document, contact: WHC/BCS Document Control Services, P.0. Box 1970, Mailstop H6-08, Richland HA 99352, Phone (509) 372-2420; Fax (509) $376-4989$.
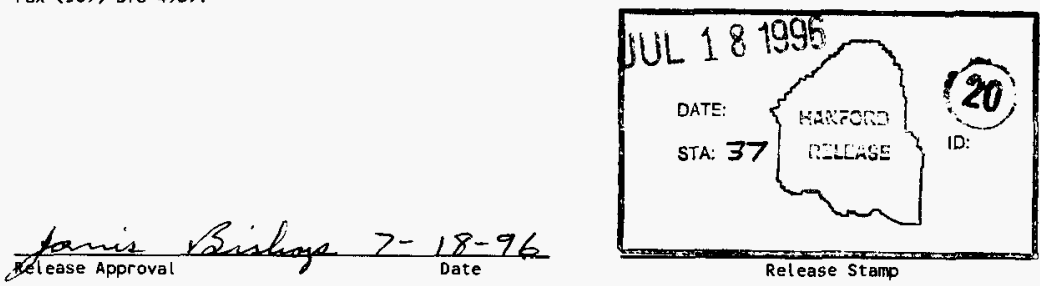

\section{Approved for Public Release}


RECORD OF REVISION

(1) Document Number

WHC-SD-WM-ATR-137

Page 1

(2) Title

RETAINED GAS SAMPLER SYSTEM ACCEPTANCE TEST REPORT

CHANGE CONTROL RECORD

(3) Revision (4) Description of Change - Replace, Add, and Delete Pages

(7) Issued on EDT 154935, December 1995

0

Revision 1 is a rewrite with changes in

1 RS text, figures, and appendices. Rev. 1 is issued on ECN 624777 .

Authorized for Release

(5) Cog. Engr . (6) Cog. Mgr. Date

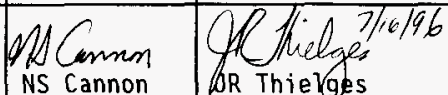

NS Cannon WR Thiekges

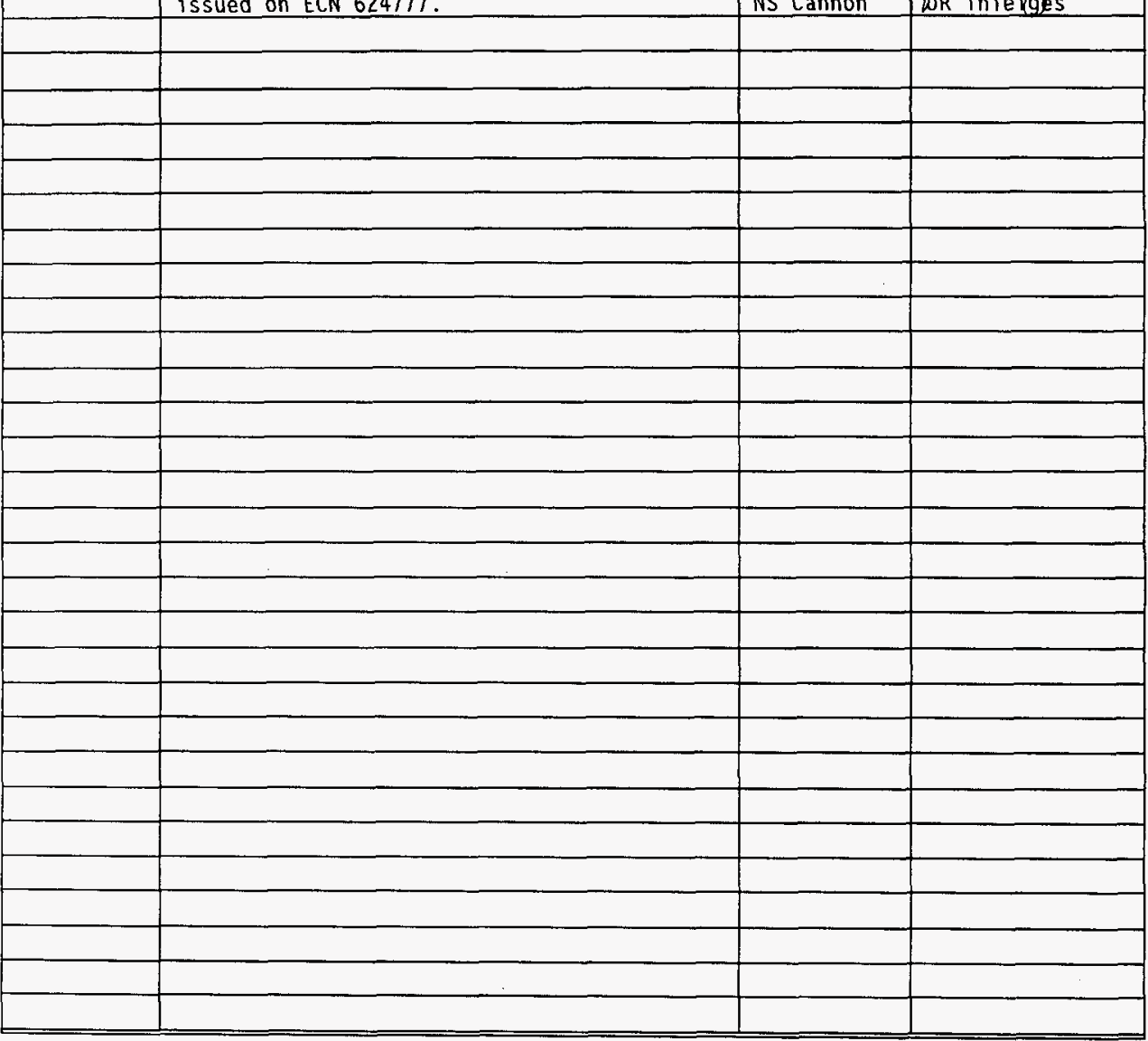


WHC-SD-WM-ATR-137

Rev. 1

Page 1

\section{RETAINED GAS SAMPLER SYSTEM} ACCEPTANCE TEST REPORT

N. S. Cannon

R. C. Knight

Ju\}y 1996 


\section{CONTENTS}

1.0 Introduction ................... . . . 5

1.1 Purpose....................... 5

1.2 Scope ...................... . . 5

2.0 References ....................... . 5

3.0 Responsibilities . . . . . . . . . . . . . . 6

4.0 Description of System . . . . . . . . . . . . . . . . 6

5.0 Test Conditions and Data Analysis . . . . . . . . . . . . . . . 7

5.1 Test Facility. . . . . . . . . . . . . . . . . . 7

5.2 Data Acquisition and Control Software . . . . . . . . . . 7

5.3 Instrument Calibration ................ 7

5.4 Preoperational Leak Test . . . . . . . . . . . . . . 8

5.5 Test Data.................... . . 8

5.5. I Gas Composition Analys is . . . . . . . . . . . . 8

5.5.1.1 Insoluble Gas Analysis . . . . . . . . . . . 9

5.5.1.2 Ammonia Solution Analysis (ASA) . . . . . . . . 9

5.5.2 Gas Quantity Determination . . . . . . . . . . . . 9

5.5.2.1 Back Fill Method . . . . . . . . . . . . 9 9

5.5.2.2 $\mathrm{Hg}$ Pump Method . . . . . . . . . . . . . . . 10

5.5.2.3 Two Volume Method . . . . . . . . . . . . . 11

6.0 Safety ........................... 11

7.0 Acceptance Test Results . . . . . . . . . . . . . . . . . . . 12

7.1 Hardware Setup/Volume Determinations . . . . . . . . . . 12

7.1.1 2nd Volume Measurement . . . . . . . . . . . . . . 12

7.1 .1 .1 Test 1 . . . . . . . . . . . 13

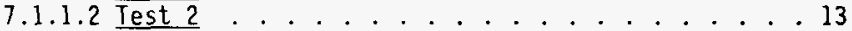

$7.1 .1 .3 \overline{\text { Test } 3}$. . . . . . . . . . . . . . 13

7.1 .2 Extractor Volume Measurement . . . . . . . . . . . . 14

7.1.3 Sampler Volume Measurement . . . . . . . . . . . . 15

7.1 .4 Extractor/Sampler Integration Test . . . . . . . 15

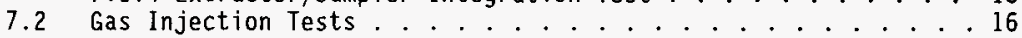

7.2.1 Required Injection Tests . . . . . . . . . . . . 17

7.2.1.1 Nitrous Oxide Gas Mix Analysis . . . . . . . . . 17

7.2.1.2 Hydrogen/Ammonia Gas Mix Analysis. . . . . . . . 17

7.2.1.3 Results Summary for Required Injection Tests . . 18

7.2.2 Additional Injection Tests . . . . . . . . . . . . 19

7.2.2.1 Ammonia Solution Analysis (ASA) . . . . . . . 20

7.2 .2 .2 RGSS Sampler Leakage . . . . . . . . . . . . . . 21

7.2.2.3 Water Deqassing . . . . . . . . . . . . . . . . 22

7.2.2.4 Wet Gas Mix Injection Test Results . . . . . . . 22

7.2.2.5 Wet Argon Gas Injection Test Resu7ts . . . . . . 23

7.2 .2 .5 .1 Composition Results . . . . . . . . . 23

7.2.2.5.2 Gas Quantity Results . . . . . . . . 24 
7.3 Simulant Extrusion Tests ................. 25

7.4 Sampler Aging Tests ... . . . . . . . . . . . . . . . 26

7.4.1 Hydrogen Seal Permeation . . . . . . . . . . . . 27

7.4.2 Sampler In-Leakage . . . . . . . . . . . . . . . . 28

7.4.3 Sampler Out-Leakage . . . . . . . . . . . . . . 28

8.0 Exceptions to ATP ..................... 29

9.0 Summary .. . . . . . . . . . . . . . . . . . . . 31

9.1 Testing and Analysis Description . . . . . . . . . . . . . 31

9.2 Acceptance Test Results .................... 32

9.3 Conclusions.................... 33

10.0 Acknowledgements . . . . . . . . . . . . . . . . . . 34

\section{Appendixes}

A RGSS Instrumentation Calibration . . . . . . . . . . . . . . . A-l

B Ammonia Solution Analysis (ASA) . . . . . . . . . . . . . . . B-1

C RGSS Raw Data Sheets . . . . . . . . . . . . . . . . . . . . . .C-1

D Adjusting Gas Composition for Leakage or Ammonia Washout . . . . . .D-1

D.1 Leakage/Outgassing . . . . . . . . . . . . . . .D-1

D.1.1 0xygen Tracer . . . . . . . . . . . . . . . . . .D-1

D.1.2 Argon Tracer . . . . . . . . . . . . . . . .D-1

D.2 Ammonia Washout . . . . . . . . . . . . . . . . . .D-2

E Acceptance Test Summary . . . . . . . . . . . . . . . . . . . . . E-1

F Hydrogen Permeation Rate for Retained Gas Sampier . . . . . . . . . F-I

G Two Volume Method Ammonia Vapor Pressure Approximation . . . . . . . G-1

G.1 Ammonia Vapor Pressure Variation on Volume Expansion . . . . . G-1

G.2 Ammonia Vapor Pressure Variation Effects on Two Volume Method

Results . . . . . . . . . . . . . . . . . .G-2

G.2.1 Insoluble Gas Quantity Error . . . . . . . . . . . .G-3

G.2.2 Ammonia Vapor Pressure Error . . . . . . . . . . . . G-5

\section{Fiqures}

1 Retained Gas Sampling System - 306E Layout . . . . . . . . . . . 56

2 Extractor and 2nd Volume Details . . . . . . . . . . . . . . . 57

3 Gas Composition Error Analysis . . . . . . . . . . . . . . . . . 58

4 Gas Quantity Error Analysis . . . . . . . . . . . . . . . . . . . 59

5 Gas Composition Difference (Measured-Expected) Is Plotted Versus

Sampler Aging Time For Hydrogen, Argon and Nitrogen . . . . . . . 60

G-1 Variation of $P_{v 1} / P_{v 2}$ versus $H / m_{L}$. . . . . . . . . . . . . . . G-7

\section{Tables}

1 NDE Leak Test Procedure and Report: 6-26-95 . . . . . . . . . . . . . 35

2 NDE Leak Test Procedure and Report: 8-14-95.................. 36

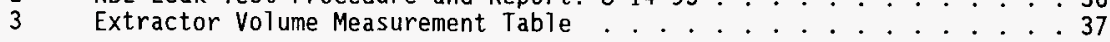




\section{CONTENTS (Cont.)}

4 Cabinet Volume Measurements . . . . . . . . . . . . 38

5 Determination of New Line Volume $(7-26-95) \ldots \ldots . . . . .39$

6 Determination of New Extractor Volume (8-15-95) . . . . . . . 39

7 Extractor/Sampler Integration Test . . . . . . . . . 40

8 Gas MIX\#1 Certificate of Analysis . . . . . . . . . . . 41

9 Gas MIX\#2 Certificate of Analysis .............. 42

10 Injection Test RGS-001 Data Sheet . . . . . . . . . . . . 43

11 Injection Test RGS-003 Data Sheet . . . . . . . . . . . . . . . . 44

12 Summary of Required Injection Test Results . . . . . . . . . . 45

13 Injection Test RGS-005 Data Sheet . . . . . . . . . . . . . 46

14 Injection Test RGS-006 Data Sheet ............. 47

15 Ammonia Solution Analysis (ASA) on MIX\#1 Control Samples . . . . . . 48

16 Injection Tests - MIX\#l Ammonia Analysis . . . . . . . . . . . 49

17 Wet (Degassed) Mixed Gas Injection Test Composition Results . . . . . 50

18 Wet (Degassed) Mixed Gas Injection Test Quantity Results . . . . . . 50

19 Wet (Degassed) Argon Gas Injection Test Composition Results . . . . . 51

20 Wet (Degassed) Argon Gas Injection Test Quantity (@STP) Results . . . 52

21 Simulant Extrusion Test Gas Quantity Results .......... . 53

22 Simulant Extrusion Test Gas Composition Results . . . . . . . . . 54

23 Sampler Aging Test Gas Composition Results . . . . . . . . . . 55

A-1 Initial (9-1-94) Calibration of MKS 10 Torr Pressure Transducer . . A-3

A-2 Final (9-15-95) Calibration of MKS 10 Torr Pressure Transducer . . .A-4

A-3 Initial (9-1-94) Calibration of MKS 100 Torr Pressure Transducer . .A-5

A-4 Final (9-15-95) Calibration of MKS 100 Torr Pressure Transducer . A-6

A-5 Initial (9-1-94) Calibration of MKS 1000 Torr Pressure Transducer . A-7

A-6 Final (9-14-95) Calibration of MKS 1000 Torr Pressure Transducer . A-8

A-7 HP-3497A DACU Cal ibration (5-30-95) . . . . . . . . . . . . . A-9

A-8 RGSS Type $K$ Thermocouple Data . . . . . . . . . . . . . . . . . . A-10

A-9 Out-of-Specification Pressure Transducer Calibration Results . . A-10

A-10 Potential Pressure Error Effect on Hg Pump Measured Gas Quantity . A-11

B-1 Preliminary MIX\#1 Ammonia D-Series Test Results..........B-3 


\section{RETAINED GAS SAMPLER SYSTEM \\ ACCEPTANCE TEST REPORT}

N. S. Cannon

R. C. Knight

\subsection{INTRODUCTION}

\subsection{PURPOSE}

This report documents the results of acceptance testing performed on and with the Retained Gas Sampler System (RGSS) in the 306E laboratory, prior to shipment of the system to the 2225 laboratory for installation and field use. The RGSS shall be used in support of the mitigation of Hanford flammable gas watch-list (FGWL) waste tanks. Acceptance testing was performed in accordance with the Retained Gas Sampler System Acceptance Test Procedure (WHC-SD-WM-ATP137).

\subsection{SCOPE}

The objective of the acceptance testing was to perform testing in accordance with WHC-SD-WM-ATP-137 (ATP) to verify that the features of the RGSS performed as designed and that the system is ready for field service. Testing was to verify that the system meets the functional design criteria specified in WHC-SD-WM-FRD-018. This testing addressed all components of the RGSS with the exception of the extruder, which is addressed in WHC-SD-WM-ATP495 and WHC-SD-WM-ATR-495. Test results, including exceptions to the ATP are documented in this test report.

This report (WHC-SD-ATR-137) of the RGSS acceptance test results generally follows the ATP format, heading for heading, allowing for a direct comparison between acceptance test requirements and acceptance test results. However, the authors note that a relatively concise summary of the test results is given in Section 9.0 of this report.

\subsection{REFERENCES}

The following documents are listed as references for the acceptance testing activities:

1. WHC-SD-WM-ATP-137, "Retained Gas Sampler System Acceptance Test Procedure." 
2. WHC-SD-WM-FRD-018, "Functional Design Criteria for the Retained Gas Sampler System."

3. WHC-SD-WM-TRP-225, "Test Results of the Phase I Test Plan."

4. WHC-SD-WM-ETP-144, "Retained Gas Sampler Engineering Task Plan."

5. WHC-SD-WM-ATP-495, "Acceptance Test Procedure for the Sample Extruder, $\mathrm{H}-2-85441 . "$

6. WHC-SD-WM-ATR-495, "Acceptance Test Report for the Sample Extruder, H-285441."

7. WHC-SD-WM-TP-328, "Retained Gas Sampler System 0peration."

8. WHC-SD-WM-TRP-232, "Retained Gas Sampler Program Proof Testing - 306E Building."

9. WHC-CM-6-1, "Standard Engineering Practices."

10. WHC-IP-0882, "306E Administration Manua1."

11. Letter Report, "Hydrogen Permeation Rate for Retained Gas Sampler," A. L. Pitner to A. E. Bridges, April 28, 1994.

12. PNLFGP: 091595, "Retained Gas Sampler System Analysis," Letter Report.

\subsection{RESPONSIBILITIES}

Primary organizational responsibilities for the Retained Gas Sampler System are outlined in the engineering task plan for the project (WHC-SD-WM-ETP-144). Organization titles and cognizant personnel may differ from those identified in the ETP. Actual names of those performing, witnessing, and approving acceptance testing are identified in this test report document. R. C. Knight acted as overall test director.

\subsection{DESCRIPTION OF SYSTEM}

The Retained Gas Sampler System is designed to capture and analyze representative samples of Hanford tank waste to determine the quantity and composition of gases trapped within the waste. The RGSS consists of three primary components: 1) the retained gas sampler (RGS), 2) the extruder, and 3 ) the extractor. The sampler is designed to capture and retain a representative waste sample--including solids, liquids, and trapped gases. The extruder is designed to transfer the entire sample from the RGS to the 
extractor. The extractor is designed to separate the gases from the liquids and solids, determine the amount of gases, remove the gas constituents for analysis, and also determine the volume of liquid and solid components of the waste sample.

A data acquisition and analysis system is also an integral part of the RGSS. This system displays, monitors, and records critical test parameters such as pressure and temperature, and did so during acceptance testing. The primary gas analytical technique involves transferring sample gas to analysis canisters for a determination of gas composition by Pacific Northwest Laboratories (PNL) utilizing a mass spectrometer (MS). An on-line gas analysis capability includes a gas chromatograph (GC) for analys is of insoluble gases; however, due to calibration time constraints, the $G C$ was not used during acceptance testing. Ammonia gas analysis, utilizing a solution absorption technique, is also included in the RGSS.

A schematic of the RGSS is shown in Figure 1, and Extractor details including the 2nd Volume are sketched in Figure 2.

\subsection{TEST CONDITIONS AND DATA ANALYSIS}

\subsection{TEST FACILITY}

The RGSS equipment acceptance testing was performed in the 300 area, $306 \mathrm{E}$ building Fabrication, Examination, and Testing Laboratory. The RGSS equipment setup was prototypic of the final equipment arrangement in the 200W area, 2225 laboratory, IE2 hot cell. Testing in $306 E$ did not simulate hot cell remote operations.

\subsection{DATA ACQUISITION AND CONTROL SOFTHARE}

Validation of the computer software used for data acquisition and control unit (DA-CU) functions was accomplished by testing the "off-the-shelf" National Instruments Labview program during RGSS system acceptance testing. The primary function that the software performs is to read data from the Hewlett Packard model 3497 data acquisition/control unit (DA/CU), convert and display the data in engineering units, and record the data to disk. These functions were tested by applying a known input to the DA/CU and verifying that the resulting parameter was displayed and recorded correctly for each data channel.

\subsection{INSTRUMENT CALIBRATION}

A11 instrumentation interfaced to the DA-CU were calibrated prior to use. Pressure and linear displacement transducers were calibrated by the WHC 
Standards Laboratory. Thermocouples have traceability to vendor calibration results. Calibration documentation is presented in Appendix A, along with an evaluation of pressure transducer drift.

\subsection{PREOPERATIONAL LEAK TEST}

The ATP required that prior to acceptance testing, the entire gas extraction system be evacuated and helium leak tested to assure that the system leak rate did not exceed $10^{-6} \mathrm{~atm} / \mathrm{cc} / \mathrm{sec}$. The leak rate was to be determined and documented with an RGS attached to the extractor vessel, alternately with the sampler valve in both the closed and open position. Also, an overall system vacuum of 1.33 Pascal $\left(10^{-2}\right.$ Torr $)$ or better was to be demonstrated.

The pretest helium leak test was performed June 26, 1995 by W. D. Purdy, and the test report is given in Table 1 . The leak rate was better than $10^{-9} \mathrm{~atm} / \mathrm{cc} / \mathrm{sec}$ (no detectable leaks were found). This leak test covered all of the extraction system identified above except in the condition with the sampler valve open. A second helium leak test was performed on August 14, 1995 (while acceptance testing was ongoing) by B. L. Hopkins; this test report is given in Table 2. This test covered the entire gas extraction system, including the condition of the sampler valve being open. The leak rate was better than $10^{-10} \mathrm{~atm} / \mathrm{cc} / \mathrm{sec}$ (no detectable leaks were found).

A pretest system vacuum as good or better than $0.001 \mathrm{KPa}$ was identified in tests RGS-047 and RGS-049, fulfilling the requirement for overall system vacuum.

\subsection{TEST DATA}

Test data, pertinent observations and exceptions to the ATP are documented in this acceptance test report (ATR). In order to verify that acceptance testing has demonstrated compliance with the design criteria specified in WHC-SD-WM-FRD-018 (FRD), as required by the ATP, analysis of the test data is required. As previously mentioned, the primary function of the RGSS is to determine the quantity and composition of gases retained in a waste tank sample within the specifications set forth in the FRD. Once the raw test data was obtained, several methods of data analysis were employed to verify compliance of the RGSS with the FRD.

\subsubsection{Gas Composition Analysis}

Composition analysis of the sample gas was performed using a mass spectrometer to determine the insoluble gas component in the sample, and an ion probe technique to measure the ammonia content of the sample. 


\subsubsection{Insoluble Gas Analysis}

Composition analysis of insoluble gas transferred from the RGSS extractor to analysis canisters was performed using PNL's 325 Building mass spectrometer, as previously described.

\subsubsection{Ammonia Solution Analys is (ASA)}

Analysis of the sample gas for ammonia was performed using a technique described in detail in the RGSS proof test report WHC-SD-WM-TRP-232 (TRP). Briefly, after sample gas has been dumped into the evacuated 2nd Volume (2ndV) of the extractor as part of gas quantification testing, the 2 ndV is isolated, and a slightly acidic solution is injected into it. This solution absorbs the ammonia and retains it (even when exposed to air) while a transfer of the solution is made to the ion probe (Orion 9512BN Ammonia Gas Sensing Electrode) testing container. From the solution's measured ammonia concentration, solution volume, gas volume and pressure, the original percentage of ammonia in the sample gas can be calculated.

A more detailed description of this ammonia analysis technique is given in Appendix B.

\subsubsection{Gas Quantity Determination}

A determination of the quantity of sample gas, as well as its composition, is an important function of the RGSS. Three methods of analyzing test data will be used to determine the quantity of sample gas. They are the Back Fill method (BF), the Hg Pump transfer method, and the Two Volume (TV) method. These analysis methods will be discussed in more detail as follows.

\subsubsection{Back Fill Method}

The Back Fill method has been described in the RGSS proof test report (WHC-SD-TRP-232). This technique allows a determination of the volume of the sample's solids and liquid $\left(V_{s L}\right)$ from the empty extractor volume $\left(V_{E X}\right)$ as

$$
V_{S L}=V_{E X}-V_{x}
$$

where

$$
V_{x}=\frac{\left(P_{a}-P_{f}\right)}{\left(P_{f}-P_{E o}\right)}\left[V_{2}+V_{L}\right]
$$


The values of $V_{E x}$ (extractor volume), $V_{2}$ (2nd Volume) and $V_{1}$ (line volume) were measured before acceptance testing was initiated. After the insoluble gas has been transferred to analysis canisters (or after previous BT measurements), the initial pressure in the extractor is measured as $P_{E O}$, and the extractor is isolated from the rest of the system. The lines and the 2 ndV are then charged with air or argon gas to a pressure of $\mathrm{P}_{\mathrm{a}}$. When the 2 ndV and extractor are reconnected, the final pressure is recorded as $P_{f}$. These steps can be repeated several times to provide redundant data for determining $\mathrm{V}_{\mathrm{SL}}$.

It should be noted that a determination of $V_{s L}$ allows a calculation of the volume of gas in the Sampler; since all Sampler volumes are premeasured $\left(V_{s}\right)$, the gas volume in the Sampler $\left(V_{g}\right)$ can be calculated as simply

$$
V_{g}=V_{s}-V_{S L}
$$

However, the BF method does not allow a direct determination of the quantity (number of moles) of sample gas. Using the value of $\mathrm{V}_{\mathrm{SL}}$ determined here, either the Hg Pump Method or the Two Volume Method can provide independent value for the number of moles of insoluble gas in the extractor.

\subsubsection{Hg Pump Method}

The mercury transfer pump shown in Figure 1 transfers sample gas from the extractor to analysis canisters for MS composition analysis. In addition, the quantity of gas transferred can also be determined using the perfect gas law, since the volumes of the analysis canisters $\left(V_{c}\right)$ and feed lines $\left(V_{f f}\right)$ were measured before acceptance testing was initiated, and at the end of each gas transfer, pressure and temperature are recorded. It has been shown (WHCSD-TRP-225) that when the Hg Pump is operated through 10 cycles, over 99 percent of the extractor gas is transferred to the collection side of the system. During acceptance testing, the $\mathrm{Hg}$ Pump was normally operated through at least 10 cycles, allowing a determination of the initial sample gas quantity from the transferred gas.

Depending on the completeness of the gas transfer, the remaining pressure in the extractor after pumping is finished is the vapor pressure of soluble gas and water $\left(P_{v}\right)$. Measurement of this vapor pressure is also a requirement of the FRD.

Thus, from the perfect gas law,

$$
n_{g}=\frac{\left(P_{f}-P_{v}\right)\left(V_{c}+V_{f 1}\right)}{R T}
$$


where $P_{f}$ is the final pressure measured in the analysis canister after gas transfer has been completed. $P_{v}$ is assumed to be the same vapor pressure in the analysis canister as remains in the extractor. of course, $R$ is the universal gas constant and $T$ is the temperature (in $K$ ).

\subsubsection{Two Volume Method}

The Two Volume method is a hybrid technique combining the Start Pressure Technique described in the proof testing report (WHC-SD-TRP-232) with the BF method to eliminate the need to know the initial pressure (potentially unavailable) in the Sampler. Once the value of $V_{s t}$ has been determined from the BT method, the number of moles of insoluble gas can be calculated as

$$
n_{g}=\left(P_{e x L}-P_{2}\right)\left(\frac{V_{x}}{V_{2}}\right)\left[\frac{V_{x}+V_{2}}{R T}\right]
$$

where $P_{\text {ext }}$ is the initial pressure in the extractor and feed lines, after a gas releasing step (like sample extrusion, mixing or dilution) has been completed and before the isolated (and evacuated) 2 ndV is combined with the extractor; $P_{2}$ is the pressure in the combined volumes.

The vapor pressure can then be calculated as

$$
P_{v}=P_{e x L}-\left[\frac{n_{g} R T}{V_{e x L}-V_{S L}}\right]
$$

where $V_{\text {ext }}$ is the sum of the feed line and extractor volumes.

Thus, the Hg Pump and Two Volume methods provide two separate and independent techniques of determining insoluble gas quantity and soluble gas/water vapor pressure.

\subsection{SAFETY}

Only the test director, cognizant test engineers, and/or their approved personnel operated the RGSS equipment. A Hanford Job Hazard Analysis Checklist and $306 E$ Specific Job Hazard Analysis Checklist were prepared and approved prior to acceptance testing. A prejob safety briefing was conducted with all test personnel. All of these steps were performed in accordance with the $306 \mathrm{E}$ Facility Administration Manual WHC-IP-0882. 


\subsection{ACCEPTANCE TEST RESULTS}

The RGSS was fabricated and assembled essentially as shown in Figure 1. Although proof testing had verified RGSS operation principles, acceptance testing as outlined in WHC-SD-WM-ATP-137 was required to verify proper system design specific to the actual hardware and operating procedures.

The RGSS ATP directed that acceptance testing be conducted in three phases as described in the following sections. The raw data for each test was recorded in one of three logbooks; HEDL-N-2603, WHC-N-1111 1 or WHC-N-96. Raw data sheets are included in Appendix $C$ for all tests that provided data used in this ATR. In performing these tests, the operating procedures specified in WHC-SD-WM-TP-328 were used as a guideline for step-by-step equipment operation.

\subsection{HARDWARE SETUP/VOLUME DETERMINATIONS}

In order to obtain gas quantity and void fraction data, it was necessary to accurately know the volumes of many of the RGSS components, including the extractor, 2nd volume, feed lines and sampler.

\subsubsection{2nd Volume Measurement}

The 2nd volume was measured by weighing it and attached components (including valves $U, Q, P, R, S$ and $T$ ) in the dry condition. Then it was filled with liquid of a known density, and reweighed. The difference in mass divided by the liquid density gives the volume; actual test details are given below.

Three tests were performed on 6-22-95. Weighing of the entire 2nd Volume hardware was performed at the WHC Standards Laboratory using scale \# 002-06-01-013. The dry mass was determined at 6816.8 grams. The $50 \mathrm{~mL}$ canister (between Valves $Q$ and $P$ ) was also weighed dry at 835.1 grams, on a different scale (Standards Lab \#677-06-01-024, located in 306E Building).

Then a fill canister was attached to the 2nd Volume through Valve $U$ using a Tygon tube. The fill canister was filled with test liquid, and the canister was raised above the 2 nd Volume. Valves $P, Q, R, S$ and $T$ were in the open position until liquid started to drain through Valve $S$. Then Valve $S$ was closed until liquid again started to drain through Valve $T$, at which point, Valve $R$ was closed. Liquid continued to fill the $50 \mathrm{~mL}$ canister until it started to drain out Valve $P$; Valves $Q$ and $P$ were then closed. (Note: the $50 \mathrm{~mL}$ canister was used in these tests to make certain that the volume through Valve $Q$ was completely filled with test liquid.)

The outside of the 2nd Volume and its accessible tubes were then dried; the $2 \mathrm{ndV}$ was reweighed (now filled with test liquid). Then the $50 \mathrm{~mL}$ canister 
was separated from the 2 ndV, and weighed on the $306 \mathrm{E}$ Building scale. Using the data obtained from these scales, the volume of the 2 ndV was determined, since the density of the test liquid was known. These tests were performed at nominally $25^{\circ} \mathrm{C}$, using water and alcohol as the test liquids; at this temperature, the density of water is $\rho_{w}=0.997 \mathrm{~g} / \mathrm{mL}$, and of alcohol is $\rho_{\mathrm{a}}=0.787 \mathrm{~g} / \mathrm{mL}$.

Three different tests were performed to measure this volume.

\subsubsection{Test 1}

The 2nd Volume was filled with deionized water and reweighed at 7182.8 grams. Then the $50 \mathrm{~mL}$ canister was removed and weighed at $886.7 \mathrm{grams}$. Thus, the total mass of water in the $2 \mathrm{ndV}$ and $50 \mathrm{~mL}$ canister was $7182.8 \mathrm{~g}-6816.8 \mathrm{~g}=366.0$ grams. The mass of water in the $50 \mathrm{~mL}$ canister was $886.7 \mathrm{~g}-835.1 \mathrm{~g}=51.6 \mathrm{grams}$. This leaves the second volume water mass at 314.4 grams, and corresponds to a volume of $314.4 \mathrm{~g} / \rho_{\mathrm{w}}=315.3 \mathrm{~mL}$ in the 2nd Volume.

\subsubsection{Test 2}

One of the concerns in using water as the liquid to fill the 2ndV was that bubbles might form, causing the volume to be determined at a lower value than it actually was. For this reason, the next two volume measurement tests were performed using an alcohol/water mix; alcohol will "wet" better than pure water, helping to minimize bubble formation.

For this test, the mix was $1600 \mathrm{~mL}$ of deionized water to $200 \mathrm{~mL}$ of ethyl alcohol. The full weight of the $2 n d V$ (including canister) was measured at 7179.3 grams; subsequently, the full $50 \mathrm{~mL}$ canister was measured at 885.9 grams. Thus, the mass of liquid in the 2 nd Volume was 311.7 grams.

The density of the combined alcohol and water is a weighted average of the individual densities. Thus, $\rho_{\mathrm{T}}=\left(\rho_{\mathrm{w}} * 1600 \mathrm{~mL}+\rho_{\mathrm{a}} * 200 \mathrm{~mL}\right) /(1800 \mathrm{~mL})=$ $0.9737 \mathrm{~g} / \mathrm{mL}$. This yields a volume of $320.1 \mathrm{~mL}$ for the 2 nd Volume.

\subsubsection{Test 3}

The third test used a different alcohol/water mix; $1600 \mathrm{~mL}$ of water with $10 \mathrm{~mL}$ of alcohol added. The full assembly was measured at 7188.5 grams; the full $50 \mathrm{~mL}$ canister was weighed at 887.0 grams. The mass of 1 iquid in the 2 ndV would then be 319.8 grams.

The density of the combined alcohol and water is $\rho_{\mathrm{T}}=\left(\rho_{\mathrm{w}} * 1600 \mathrm{~mL}+\right.$ $\left.\rho_{\mathrm{a}} * 10 \mathrm{~mL}\right) /(1610 \mathrm{~mL})=0.9957 \mathrm{~g} / \mathrm{mL}$. This yields a volume of 321.2 for the 2nd Volume.

The addition of alcohol to water to form the test liquid increased the measured volume, as expected. Only the two alcohol/water tests were used in 
the final determination of the 2 nd Volume. The average of these two test results gives $V_{2}=320.64 \mathrm{~mL}$.

\subsubsection{Extractor Volume Measurement}

The ATP requires that the volume of the extractor will be measured using a known quantity of gas introduced into the previously evacuated extractor. The extractor volume can then be calculated using the perfect gas 1 aw, based on the measured pressure changes (at constant temperature).

The ATP requires that these measurements be repeated at least 10 times. This test was first performed on 6-27-95, and Table 3 gives the results. This data table is slightly modified from the one described in the ATP to allow the determination of the $l$ ine volume (from Valves $B$ and $Z$ to Valves $R$ and $T$, see Figure 1). The 3 and the 2 are transposed in Table 3 for the Measured 2 nd Volume value; the intended number was $320.0 \mathrm{~mL}$. For this value, the average extractor volume was $V_{E x}=1349.7 \mathrm{~mL}$, while the average line volume was $V_{L}=220.9 \mathrm{~mL}$. Subsequent reevaluation of the 2 nd Volume measurement indicates that $V_{2}=320.64 \mathrm{~mL}$ is a better value; then $V_{E X}=1352.4 \mathrm{~mL}$ and $V_{L}=221.3 \mathrm{~mL}$.

The RGSS ATP requires that the standard deviation for the extractor volume results be 0.3 percent (or less) of the average volume determined (see WHC-SD-WM-FRD-018). The standard deviation for the above extractor volume measurements was 0.15 percent of the average value, well with in the requirement.

Although not included in the ATP, it is important (particularly for the Hg Pump Method) to know volumes within the RGSS cabinet on the analysis canister side of the $\mathrm{Hg}$ transfer pump. These volumes were measured by using a charge of argon gas in the line volume, and dumping the gas sequentially through the previously evacuated volumes as defined in Table 4 . The average values of these determined volumes are also given in Table 4.

A change was made on 7-26-95 to the feed lines coming to the extractor which resulted in a change in the line volume. A new line volume measurement was made by charging the 2 nd Volume to a given starting pressure, evacuating the line volume, and then dumping the 2 nd Volume into the line. These measurements are given in Table 5, and result in a new line volume of $V_{L}=199.95 \mathrm{~mL}$. This is the line volume value that is used for analysis of a11 RGSS acceptance tests performed after 7-26-95.

Also, a change was made on 8-15-95 to the extractor. A new piston stop was welded into the extractor for the extractor/sampler interface; although not expected to change significantly, the extractor volume was remeasured as a precaution. The results are give in Table 6 , and the average over ten tests was $V_{E X}=1354.0 \mathrm{~mL}$, with a 0.04 percent standard deviation. This is the value of the extractor volume that was used for analysis of all RGSS acceptance tests performed after 8-15-95. 
It should be noted that in all cases, the volume of the extractor measured in this Section included the stirrer and all internal extractor apparatus that will be used with actual tank waste samples.

\subsubsection{Sampler Volume Measurement}

The three prototypic Samplers that were used for essentially all of the acceptance testing each had a volume measurement made using the water fill (dry and full weighing) technique. After dry weighing, the Samplers were completely filled with deionized water; when the ball valve was closed, the valve remained completely submerged in water so that no air bubbles were trapped in the closing process. Since the Sampler barrel was a simple cylinder, visual examination was made for bubbles before the ball valve was closed. After external drying, the following volume measurements were made for the respective Samplers indicated:

\begin{tabular}{|c|c|c|}
\hline Sampler & Date & Measured Volume (mL) \\
\hline$\# 1$ & $\overline{7-12-95}$ & 314.63 \\
\hline \#2 & $7-18-95$ & 315.26 \\
\hline$\# 3$ & $7-18-95$ & 315.08 \\
\hline
\end{tabular}

These three Samplers were fully prototypic of production units (including passing a 3 atmosphere helium leak-check criteria specified in the FRD), once leakage problems to be discussed in Section 7.2.2.2 were solved.

\subsubsection{Extractor/Sampler Integration Test}

To verify the proper operation of the extractor and sampler together (including verification of measured volumes for extractor and 2nd volume), the ATP requires the performance of a start pressure test (SPT) in which the sampler is filled with air at a measured pressure (atmospheric) and temperature (ambient). The SPT, described in WHC-SD-WM-TRP-232, was to be performed with a resulting determination of the starting gas volume/quantity within the FRD specifications.

This SPT test (RGS-007) was performed (7-14-95), and the raw data results are given in Table 7 . Sampler \#1 was loaded with 754.8 Torr (100.64 $\mathrm{KPa}$ ) of air at $21{ }^{\circ} \mathrm{C}$, which corresponds to $n_{9}=0.01295$ moles of air at STP.

From WHC-SD-WM-TRP-232, the following SPT equations are reproduced for convenience:

$$
V_{S L}=\frac{\left[\left(V_{E X L}-V_{s}\right)\left(V_{E X L}+V_{2}\right)-k V_{E X L}\left(V_{E X L}+V_{2}-V_{s}\right)\right]}{\left[V_{E X L}-V_{s}-k\left(V_{E X L}+V_{2}-V_{s}\right)\right]}
$$


and

$$
n_{g}=\frac{\left[\left(P_{s}-P_{2}\right)\left(V_{s}-V_{S L}\right)\left(V_{E X L}-V_{S L}+V_{2}\right)\right]}{\left[\left(V_{E X L}+V_{2}-V_{s}\right) R T\right]}
$$

where $k=\left(P_{s}-P_{E X}\right) /\left(P_{s}-P_{2}\right), P_{s}$ is the "start" pressure in the Sampler, $P_{E X}$ is the pressure in the extractor after the Sampler ball valve has been opened and the piston extended, and $P_{2}$ is the pressure in the combined extractor and 2ndV. These two equations are slightly modified in appearance from the way they appear in the TRP in that $V_{E X L}=V_{E X}+V_{L}$ has be substituted for $V_{E X}$, as is correct for the present RGSS hardware configuration.

$V_{s}$ is the volume of the Sampler $(314.63 \mathrm{~mL})$, and $P_{s}=102.04 \mathrm{KPa}$ (compensated for the change from 21 to $25.1{ }^{\circ} \mathrm{C}$ ), $P_{E x}=20.38 \mathrm{KPa}$ and $P_{2}=$ 16.96 KPa. $V_{E X L}=1352.4+221.3=1573.7 \mathrm{~mL}$ (note the corrected difference from the value reported in Table 7 ). With these values, the calculated results for this test are $V_{s L}=3.72$ (should be 0 ), and $n_{g}=0.01277$ moles; this represents a -1.4 percent error when compared to the expected value of 0.01295 moles. This error is well within the allowable limits of the FRD ( $2 \%$ absolute error is the specification).

\subsection{GAS INJECTION TESTS}

Gas injection tests were performed to verify the ability of the RGSS to provide the correct (within specifications) gas composition analysis and quantity determination of a known gas mix injected directly into the evacuated extractor through the dilution port, without the use of a Sampler. Tests were conducted with an RGS mated to the extractor with the ball valve open and piston in the forward position. The ATP required four injection tests; however, many additional injection tests were performed and will be described after reporting the results of the required tests.

The ATP specified that for each injection test, two samples of the known gas were to be obtained simultaneously from the same gas source. One sample was to be used as a control while the second was to be injected directly into the extractor through the dilution port. Both SPT and backfill test (BT) procedures (see WHC-SD-WM-TRP-232) were to be performed to measure the quantity of the injected gas, allowing a comparison of the result with the known value. However, in an ATP change, only one control sample was obtained for each type of gas used in injection testing because of the reliability of the mass spectrometer composition analysis. Also, only the $\mathrm{Hg}$ Pump method was used to determine gas quantity for the four ATP required injection tests. 


\subsubsection{Required Injection Tests}

Injection tests were performed at both ambient and $50^{\circ} \mathrm{C}$ for each of the two control gas mixes, giving a total of four required injection tests. According to vendor certification, gas MIX $\# 1$ contains ammonia (5.0\%), argon $(24.9 \%)$, hydrogen (30.3\%) and nitrogen (39.8\%); MIX\#2 contains nitrogen $(30.0 \%)$, nitrous oxide $(30.8 \%)$ and helium $(39.2 \%)$. Vendor certification for these gas mixes are given in Tables 8 and 9 , respectively. These control gas mixes were chosen to include gas components in roughly the same relative percentages expected from a "typical" flammable gas waste tank (101-SY); two mixes were used in order to separate the potentially explosive combination of hydrogen and nitrous oxide.

\subsubsection{Nitrous Oxide Gas Mix Analysis}

Gas MIX\#2 was used in the first injection tests. A control gas sample (1abeled RGS-002) was obtained in a $40 \mathrm{~mL}$ canister at the same time another $40 \mathrm{~mL}$ canister was filled for injection test RGS-001, performed at ambient temperature. The raw data results from test RGS-001 are given in Table 10; $\mathrm{Hg}$ transfer pumping of the gas to the collection canister (Jl) resulted in a final pressure reading of $63.48 \mathrm{KPa}$ at a cabinet temperature of $32.3^{\circ} \mathrm{C}$.

The second injection test (RGS-003) for this gas mix was performed at an extractor temperature of nominally $52.7{ }^{\circ} \mathrm{C}$. The raw data results from this test are given in Table 11. After gas transfer, the final pressure in the analysis canister $\mathrm{J} 2$ was $59.06 \mathrm{KPa}$ at a cabinet temperature of $31.7{ }^{\circ} \mathrm{C}$.

Table 12 gives both the gas composition analysis (including the control sample) and gas quantity results for these two tests.

\subsubsection{Hydrogen/Ammonia Gas Mix Analysis}

Gas MIX\#l was used in the remaining two required injection tests. A control sample (labeled RGS-004) was obtained at the same time as the injection test sample RGS-005. The raw data results from test RGS-005 (performed at ambient temperature) are given in Table 13; the $\mathrm{Hg}$ pump transfer of gas to the analysis canister resulted in a final pressure reading of $59.57 \mathrm{KPa}$ at a cabinet temperature of $32.3^{\circ} \mathrm{C}$.

Test RGS-006 was performed (using MIX\#1 gas) at nominally $52.4{ }^{\circ} \mathrm{C}$; raw data from this test are given in Table 14. The final pressure in the analysis canister after $\mathrm{Hg}$ pump gas transfer was $56.43 \mathrm{KPa}$, with a cabinet temperature of $29.5{ }^{\circ} \mathrm{C}$.

Gas composition analysis (MS) and gas quantity results for RGS-005 and RGS-006 are also reported in Table 12 . 


\subsubsection{Results Summary for Required Injection Tests}

As previously mentioned, a results summary for the required injection tests using two gas mixes is given in Table 12.

For the simpler nitrous oxide gas mix (MIX\#2), the composition test results are straight forward. The vendor and MS control sample (RGS-002) results are within 0.4 percent agreement for all three gas components in this mix. Both the ambient and $50{ }^{\circ} \mathrm{C}$ injection tests had composition results that were within 2.7 percent of the vendor (or control) compositions; the FRD requires only a 6 percent agreement for these gas components at these percentage levels.

When adjusted for "leakage", using oxygen as a tracer (see Appendix D), the MIX\#2 injection test agreement is within 0.4 percent of the vendor or control sample composition for both test conditions. It should be noted that the "leakage" noticed (particularly for test RGS-001) is the result of offgassing from the chamber walls rather than from actual system leakage. Whenever, the system is exposed to air, an extensive vacuum pump down over a long period of time (overnight is recommended) is required to reduce this offgassing effect.

The hydrogen/ammonia gas mix (MIX\#1) composition analysis results are more complicated because of the "washout" of ammonia experienced in processing the gas through system tubing and canisters. A comparison of the vendors composition with the control sample's (RGS-004) shows a significant difference in ammonia levels. This washout also affects the remaining gas components' relative percentages.

A calculational method for compensating ammonia washout by using the "known" value for ammonia, and adjusting the relative percentages of the remaining gas components for ammonia loss, is given in Appendix $D$. Ammonia loss compensation was used for the control sample results as shown in Table 12; this improved the agreement between the vendor and control sample results, with the largest difference being 0.9 percent for nitrogen.

The control sample's MS composition was adjusted for the change from 2.9 percent ammonia to 1.4 percent for comparison with the RGS-005 results after testing at $28.0^{\circ} \mathrm{C}$. The 1.5 percent difference for hydrogen between the control and test results is the largest for the measured gas components, but still within the FRD requirement of an absolute difference of 2 percent for hydrogen. (The FRD allowance of \pm 20 percent relative difference for other gas components is much more lenient than for hydrogen, allowing an absolute difference of \pm 6 percent for an actual level of 30 percent.) When the "leakage" adjustment is performed, the largest difference between control and test values shrinks to 0.4 percent for hydrogen.

Similarly, the control sample's MS composition was adjusted for the change from 2.9 percent ammonia to 1.8 percent for comparison with the RGS-006 
results after testing at $52.4{ }^{\circ} \mathrm{C}$. The 0.3 percent difference for argon between the control and test samples was the largest noted. When the "leakage" adjustment was performed, the maximum difference between control and test compositions increased slightly to 0.4 percent for nitrogen. These test results are clearly within the specifications of the FRD.

Also presented in Table 12 are the analysis results for gas quantity for these four injection tests, based on the $\mathrm{Hg}$ Pump Method. These results are presented in terms of gas volumes at Standard Temperature and Pressure (STP) conditions. The "adjusted ( 2 ndV) gas" volume is a adjustment to compensate for the gas dumped into the 2nd Volume that was not transferred to the analysis canister portion of the RGSS. This adjustment was accomplished using a simple ratio of the affected system volumes multiplied by the "final canister gas" volume. Errors between the initial starting gas volume and the volume determined from the Hg Pump Method for these four tests were 3 percent or less. The FRD allows a relative error of \pm 20 percent for these gas quantities.

The ammonia solution absorption (ASA) technique for ammonia analysis determined the ammonia concentrations at 2.1 percent and 2.7 percent for tests RGS-005 and RGS-006, respectively. These values for ammonia concentration are better than those determined from the mass spectrometer as reported in Table 12, but significantly lower than the expected 5.0 percent. They do not meet the FRD requirement for ammonia (which allows an absolute error of \pm 2 percent for these conditions); a result of at least 3 percent is required for an actual 5 percent ammonia gas mix.

MIX\#1 gas had been previously tested (directly from the gas bottle to $40 \mathrm{~mL}$ canisters, followed by absorption into solution) using the ASA technique, with the average result over seven tests of 5.05 percent, verifying the vendor certification (although a large standard deviation of about 1 percent was observed). These test results are reported in Table 15.

Under these test conditions, the results for the four required injection tests verified compliance of the RGSS with the FRD for gas quantity analysis and composition analysis, with the exception of ASA ammonia gas analysis.

\subsubsection{Additional Injection Tests}

Many more gas injection tests (than were required in the ATP) were performed because these tests provided a valuable tool in trouble shooting problems that developed during the RGSS acceptance testing. In addition, injection tests were performed to gather more data under combined gas and water simulate test conditions to supplement (at lower cost) the limited number of full scale simulant extrusion test results.

Three types of problems were encountered during acceptance testing; ammonia analysis accuracy, leaking samplers and degassing water simulant. Additional injection tests were used to evaluate all three of these problems. 
Ammonia analysis accuracy remains outside the FRD specification. The leakage of samplers was identified, and a change in sampler assembly procedure was made to eliminate this problem. Degassing of water during a simulant test altered the gas composition, producing an apparent error; this problem was solved by degassing the water prior to adding the simulant gas to the sample. It should be noted that the water degassing problem was not caused by an RGSS hardware or procedure failure; it was caused by initially failing to recognize that ordinary aerated water would create a simulation problem.

A complete list of all acceptance tests performed (including problem tests) is given in Appendix E. Only those tests that provide useful data will be analyzed in the remaining report that follows.

\subsubsection{Ammonia Solution Analys is (ASA)}

A series of injection tests were performed to more fully evaluate the analysis of ammonia gas concentration using the acid solution absorption technique. The test results are reported in Table 16, and include the two required injection tests RGS-005 and RGS-006 previously described.

For tests RGS-005 and RGS-005, during ASA ammonia ana1ysis a brown precipitate formed in the test solution when its $\mathrm{pH}$ was adjusted (to between 12 and 14), releasing the trapped ammonia to the ion probe. It was thought that welding contaminants remaining inside the 2 nd Volume might have caused the precipitate, so the 2 ndV was recleaned with acid. Informal tests $A-1$ and A-2 were performed to verify the success of the cleaning process; no precipitates were observed, and the ammonia results were much better (at 4.6 percent). However, low ammonia concentrations were later measured for the three subsequent tests, also without the appearance of the precipitate. Thus, it appears likely that the precipitate was not related to the low ammonia readings.

Schedule considerations prevented further study of this ammonia analysis problem. It was decided to finish other aspects of the RGSS acceptance testing and move towards installation and operation of the system, recognizing that the ammonia analysis method failed to pass the requirements of the FRD.

Any future evaluation of the ammonia analys is problem should start by looking at the stirring motor splash shield and sleeve (Drawing H-2-821610, Rev 0, Sheet 9, Item 35). The Drawing specifies that this sleeve be made with ultra high density polyethylene; tests should be made to see if replacing the polyethylene with $304 \mathrm{~L}$ stainless steel improves ammonia analysis performance, since many materials absorb ammonia. Other than the essential viton vacuum seals (copper seals are known to absorb ammonia), the polyethylene is the only non stainless steel material inside the RGSS extractor and 2nd Volume.

There are other possible explanations for the low ammonia readings. The stainless steel walls of the extractor and 2nd Volume may pull some of the ammonia out of a gas mix to coat the wall surfaces. Mockup tests should be 
performed with different sized stainless steel containers using a constant quantity of gas to see if the ammonia concentration is reduced with increasing container size. Also, the wide variation of results noted in Table 16 may be related to how well the system has been dried out prior to testing; residual water (even in small quantities) would absorb ammonia, and may account for the wide variation in results.

The injection tests performed provide a limited amount of ammonia (only what is in the gas); actual waste samples may contain a significantly larger reservoir of ammonia "in solution". In such a case, walls would become saturated with ammonia with a minimal decrease in the ammonia concentration in the gas. A more appropriate simulation of this condition (than gas injection tests) would be to use a aqueous ammonia solution with a known ammonia vapor pressure as the simulant.

All of the above steps should be taken to characterize the response of the RGSS system to different ammonia gas source conditions. Multiple ammonia tests for the same tank sample could be used to investigate the ammonia "reservoir" content of the waste sample.

\subsubsection{RGSS Sampler Leakage}

All RGSS samplers were leak tested prior to use, and found to be leak tight. However, as a result of the low resistance provided by the water or Carbopol $\Theta^{*}$ simulants, the sampler piston often "slammed" forward with high impact during extrusion because of the pressure difference between the evacuated extractor and the external atmosphere on the other side of the piston. During most of the early simulant extrusion tests (to be discussed later), the system began leaking immediately after the extrusion step. This effect was traced to leakage through the threads of the sampler 0-Ring Insert Assembly (H-2-821608, Sheet 2, Item 23) mated to the Valve Housing (same drawing, Item 9).

This sampler leakage path had been sealed using Varian Associates' "Torr Seal" vacuum epoxy per the manufacturer's specifications. The low vapor pressure Torr Seal hardened to a fairly stiff bead on the interface between Items 23 and 9 and in addition to providing leak protection, also prevented the insert from turning during sampler handling. However, this bead was found to have cracked for those samplers where a post extrusion leak had developed.

This leakage problem was solved by changing the sampler assembly procedure; Torr Seal was put on the threads of Item 23 prior to sampler assembly as well as being used to form a bead between the insert and valve housing after assembly. Once this step was added to the sampler assembly

\footnotetext{
- Carbopol is a trademark of the B. F. Goodrich Company
} 
procedure, no sampler was found to have leaked during the remaining thirtyfive acceptance tests (including the final six extrusion tests).

\subsubsection{Water Degassing}

Deionized water was used as a simulant for the solid/liquid portion of a sample in many acceptance tests. Initially, this water was used in its ordinary aerated form. In this form, the water ruined composition analysis tests by discharging dissolved air into the vapor space, thus changing the expected composition of the gas. At the same time, total gas quantity increased, particularly during $\mathrm{Hg}$ Pump gas transfer, since air was sucked out of the water during this low pressure operation.

Starting with acceptance test RGS-024 and on through RGS-053, when a water simulant was used, it was degassed prior to test performance. This was done by evacuating the container for the water (extractor or sampler) several times below the vapor pressure of water, then allowing it to sit overnight (usually), and re-evacuating the container again. Composition analysis results improved significantly for degassed water tests. Gas quantity results were reduced below expected levels (although within FRD requirements) as measured by the $\mathrm{Hg}$ Pump analysis method; this was to be expected as some of the injected test gas would be absorbed by the degassed water.

\subsubsection{Wet Gas Mix Injection Test Results}

Five additional gas MIX\#2 "over" water injection tests were performed and also one MIX\#1 injection test. The water simulant for these tests was left in the extractor from previous tests, and degassed in-situ before the initiation of each test. Initially, about $300 \mathrm{~mL}$ of water had been added to the extractor; at the end of testing, over $250 \mathrm{~mL}$ remained (as crudely remeasured in a beaker - not including some residual water left in the extractor and elsewhere). Since water was evaporated during each degassing cycle, the precise $V_{s L}$ was not known, and the Back Fill Technique was not used to measure it, as the BT measurement accuracy could not be cross verified.

The composition results for these tests are reported in Table 17, and excellent agreement was achieved as compared with the control samples, except in the case of RGS-029. This test was performed with only $2.5 \mathrm{~mL}$ (at STP) of gas, which appears to define a minimum gas volume limit for RGSS composition analysis accuracy. Except for RGS-029, all the Table 17 test results, as compared with control sample compositions, are within the specifications required by the FRD.

Gas quantity determinations based on the $\mathrm{Hg}$ Pump method for these tests are given in Table 18 . All of the determinations underestimate the initial starting injection quantity, which is consistent with some of the injection gas being absorbed by the degassed water simulant. However, all of these test results (except RGS-037) are within the FRD requirement that the ratio of gas volume to bulk waste volume have an absolute accuracy of \pm 2 percent. The 
bulk waste volume (assuming complete filling of a sampler) would be $315 \mathrm{~mL}$; 2 percent of this bulk volume corresponds to $6.3 \mathrm{~mL}$ of gas. 0 lly the RGS-037 difference between start quantity and $\mathrm{Hg}$ Pump transferred quantity of $6.41 \mathrm{~mL}$ slightly exceeds this FRD specification. But if the fact that upon injection, all of the ammonia was immediately absorbed in the water is accounted for, the gas start quantity is reduced to $35.36 \mathrm{~mL}$ and the transfer difference is only $4.68 \mathrm{~mL}$, well within the FRD requirement.

Thus, it is concluded that for the six gas MIX\#1 and MIX\#2 injection tests performed in the presence of degassed water simulant, all RGSS composition and quantity analyses produced results within the FRD requirements for accuracy (with the exception of test RGS-029, for which the initial $2.5 \mathrm{~mL}$ gas volume is presumed too small for accurate RGSS composition analysis).

\subsubsection{Wet Argon Gas Injection Test Results}

Tables 19 and 20 list analysis results for gas composition and quantity, respectively, of RGSS injection tests using argon gas and degassed water simulants. A single component gas (argon) was used as the simulant gas in these tests to simplify the analysis interpretation of leakage and outgassing effects. The primary purpose of the argon gas injection test series was to correlate composition analysis accuracy with the initial gas quantity injected; however, the $\mathrm{Hg}$ Pump Method was also used to determine gas quantity.

Three of these argon injections tests included an elevated temperature and "mixing" excursion to nominally $50{ }^{\circ} \mathrm{C}$; these are tests RGS-047, RGS-049 and RGS-050. Previously, it had been found that gas transfer at these elevated temperatures resulted in water condensing and plugging the filter (located as shown in Figure 1). Thus, the extractor and second volume valves ( $R$ and $T$ ) were closed while the temperature was above ambient during these tests. Gas transfer to the analysis canister took place after the temperature had been reduced to ambient.

While above $50^{\circ} \mathrm{C}$, the mixer motor (with blades attached) was operated for 10 minutes at about 15 RPM to simulate stirring waste; this length of time should be long enough to drive out most actual waste gas bubbles in the presence of a near vacuum. It is recommended that the mixing motor operation be limited, since the vacuum feedthrough bellows failed and had to be replaced after only a few hours operation in prior testing.

\subsection{Composition Results}

Two control gas sample analyses were performed and both produced a 99.95 percent argon result. The composition results from the remaining argon injection tests were compared with these control sample values in Table 19; an error value was recorded for each test. A plot of this error versus initial gas quantity is made in Figure 3. Also included in Figure 3 is error data from the mixed gas injection tests; error for mixed gas tests was defined as 
the maximum difference between control and test gas composition for any of the major components (excluding ammonia).

Again, with the exception of RGS-029 (MIX\#2 at $2.5 \mathrm{~mL}$ ), all of the data given in Figure 3 satisfies the FRD requirements.

It should be noted that the FRD composition error requirement is 20 percent (relative) for each gas species. Thus, for single component argon gas, a 20 percent absolute error is acceptable; however, for nitrous oxide (for example) at 30 percent of the total, only a 6 percent absolute error is allowed. Regardless of actual composition, a 2 percent absolute error is within the FRD requirement. Hydrogen has a special requirement that for all composition levels, the hydrogen concentration must be measured to within 2 percent absolute accuracy.

Based on the data presented in Figure 3 and Tables 17 and 19 , adequate composition analysis accuracy has been demonstrated for initial gas volumes (at STP) as low as $5 \mathrm{~mL}$. This quantity of gas would, for example, correspond to a sample void fraction of about 0.7 percent if the sampler were full and at a pressure of 2.5 atmospheres (a pressure level consistent with lower 101-SY tank levels).

\subsection{Gas Quantity Results}

The argon injection test gas quantity results given in Table 20 are plotted in Figure 4 ; i.e., the absolute value of the gas quantity error (based on the worst case results of $P_{v} \neq 0$ ) was plotted versus initial injection gas volume (expected $V_{g}$ ). Also plotted in Figure 4 are the gas quantity results for the mixed gas compositions given in Table 18. All of these gas quantity results in Tables 18 and 20 were obtained using the $\mathrm{Hg}$ Pump Method.

Only the RGS-047 argon injection test result exceeds the FRD error limit for gas quantification (by roughly a factor of two). However, this particular large error can be explained as the result of a lower than normal temperature during gas transfer to the analysis canister. At the end RGS-047, the extractor temperature was lowered to $15.6{ }^{\circ} \mathrm{C}$ to investigate the resulting lower water vapor pressure effects on gas transfer. Thus, gas was transferred at a temperature $5{ }^{\circ} \mathrm{C}$ lower than for any of the other RGSS acceptance tests; however, the reduced temperature also caused more of the test gas to be dissolved in the water than for the higher temperature tests. The Hg transfer pump was not able to drag this extra dissolved gas from solution in just 10 cycles.

In fact, for all of the tests covered in Figure 4 , the test results underpredict the actual quantity of injected gas. The major reason for this error is believed to be absorption of the test gas in the degassed water. Degassing the water was necessary to perform valid composition analysis testing, but this step also affected the quantity results because the $\mathrm{Hg}$ pump was unable to remove all of the dissolved gas from the water. However, this 
was not a significant problem, since the quantity results were still within the requirements of the FRD when the gas transfer was performed at ambient temperature.

A second potential reason for the underprediction of gas quantity using the Hg Pump Method is the difficulty in properly accounting for the water vapor pressure. The vapor pressure of water in the analysis canister can range from zero to the full $P_{v}$ expected in the presence of liquid water, depending on how much water is transferred with the Hg pump. In Table 20, the gas quantity results are calculated using Equation (4) both with $P_{v}$ equal to that measured in the extractor, and also with $P_{v}=0$ (for which the error is reduced). The results plotted in Figure 4 assume the larger error, in order to be conservative.

\subsection{SIMULANT EXTRUSION TESTS}

The purpose of these extrusion tests was to verify the RGSS capability (including the extruder) to transfer the simulant from the sampler to the extractor, to mix the simulant in the extractor to drive out gas bubbles, and to transport the simulant gas from the extractor to the collection canisters.

The ATP specified that extrusion tests be performed using water or Carbopol simulants for the liquid/solid component of the waste, and air or helium to simulate the waste's gas content. The requirements of the ATP were exceeded in that a gas composition analysis was also performed for each test. Tests were to be performed at both ambient and $50^{\circ} \mathrm{C}$ for each simulant condition identified below. A minimum of one simulant test was to include a 2:1 dilution of the sample with water as a proof-of-principal test of the method proposed to release bound gases from the waste.

Argon was substituted for air in the above ATP requirements. Carbopol tests were performed (RGS-018 and RGS-019), but Sampler leakage and Carbopol degassing invalidated these results. It was not possible to degas Carbopol, so that these tests were not repeated. Without the Carbopol simulant, the dilution (2:1) of the simulant was not performed, since the simulant was already water.

Three simulant extrusion tests were performed; results are given in Table 21 for gas quantity analysis, and in Table 22 for gas composition analysis. 0nly water was used as the solid/liquid simulant for these extrusion tests; argon was used as the simulation gas for the first two tests, and helium in the last test. The first test (RGS-051) was performed entirely at ambient temperature. The last two tests (RGS-052 and RGS-053) both included a high temperature (nominally $50^{\circ} \mathrm{C}$ ) excursion to allow a ten minute operation of the mixer at that temperature.

Examining Table 21 , it can be noted that all gas quantity results were within the FRD accuracy requirements except for the RGS-052 Two Volume 
analysis; this TV analysis overpredicted the gas quantity by $7.7 \mathrm{~mL}$ where only $6.3 \mathrm{~mL}$ is allowed by the FRD. The TV analysis overpredicted gas quantity, whereas, the $\mathrm{Hg}$ Pump technique underpredicted gas quantity as it did for the previously discussed injection tests. The vapor pressure predictions were significantly better for the TV analysis method than for the Hg Pump method.

The gas composition results in Table 22 are well within the FRD requirements for all three tests. It is interesting to note that test RGS-052 had a significant nitrogen/oxygen component (air) of about 8.6 percent, indicating either leakage or (more likely) further degassing of the water during testing. This extra air would account for about $2.5 \mathrm{~mL}$ of the TV gas quantity overprediction for this test, placing that test result within the FRD requirement (if the air is the result of further degassing).

\subsection{SAMPLER AGING TESTS}

Although not required by the ATP, four "aging" tests were performed to investigate the ability of a sampler to retain its gas with minimal leakage over an extended period of time. (After a sample is obtained from a waste tank, it may not be possible to test it immediately.) Also of interest was the possible loss of hydrogen into sampler seals.

The maximum internal pressure in samplers is expected to be in the 2.5 atmosphere (absolute) range; however, these aging tests were performed at roughly one atmosphere internal pressure (and in one case, at 0.33 atmospheres). There was no need to perform these tests at higher pressure, as the in-leakage rate for oxygen (a tracer for air) would be essentially independent of internal pressure; thus, a lower pressure test would provide greater leakage sensitivity based on the relative oxygen composition. Hydrogen absorption rate in seals is proportional to pressure (Pitner letter report), resulting in the same gas composition ratio changes, independent of pressure.

These tests cover an aging time of from 24 to 1829 hours. Three different samplers were pressurized with a 30 percent hydrogen gas (MIX\#1; see Table 8) at approximately atmospheric pressure, with the fourth sampler pressurized at about a third of an atmosphere (absolute). The results are reported in Table 23 .

The differences between the gas concentrations measured from the four aged samplers and the concentrations expected (assuming no leakage or hydrogen absorption) are plotted in Figure 5 for the primary test gases (hydrogen, nitrogen and argon). It should be noted that ammonia loss is expected during PNNL's Mass Spectrometer analysis, and this loss will alter the relative composition of other gas components. Thus, calculations were performed (as described in Appendix D) to compensate for the decreased ammonia concentrations actually measured; these calculations (based on RGS-004 control data) produced the "expected" compositions (COMP 1, 2, and 3) shown in 
Table 23 for comparison with test results. The RGS-004 control data was used for the expected composition calculations because this allows these comparisons to be made with all gas composition analysis performed by the same high accuracy mass spectrometer.

Measured hydrogen levels were slightly higher than expected $(+0.4$ to +1.2 percent, absolute) in all four aged samplers, but these results are still well within the (most stringent) FRD requirement of \pm 2 percent (absolute) error for hydrogen, as can be seen from Figure 5 . The argon and nitrogen measurements are in even better agreement with the expected concentration values, whereas the FRD is more lenient with these gases, allowing more than \pm 5 percent (absolute) error at these levels (20 percent relative error).

\subsubsection{Hydrogen Seal Permeation}

The surplus of hydrogen suggests that seal permeation losses were not significant over the time period examined, and although there appears to be a general decrease in hydrogen over time, this effect is likely due to data scatter. Note that the MS measurements have an error bars of \pm 0.6 and \pm 0.3 percent for hydrogen and ammonia, respectively. Accounting for the ammonia uncertainty, the hydrogen error bars are increased to \pm 0.7 percent for expected concentration calculations.

Thus, assuming maximum errors, the expected composition for the RGS-058 test might be as high as 30.8 percent hydrogen, whereas the actuat hydrogen concentration might be as $10 \mathrm{w}$ as 29.9 percent. The worst case hydrogen loss during the RGS-058 sampler aging test would thus be 0.9 percent absolute (2.9 percent, relative) which is acceptable over this 1829 hour (76 day) aging time. This assessment of acceptability is based on FRD compliance; a real hydrogen loss of 0.9 percent combined with the MS measurement error of 0.6 percent would produce a maximum error of 1.5 percent (conservatively), well within the 2.0 percent FRD requirement. There was no evidence during ATR testing that other sources of error such as processing the gas sample through the extractor produces errors exceeding the MS measurement error bars of \pm 0.6 percent (see hydrogen composition results for injection tests RGS-005, RGS-006 in Table 12 and RGS-037 in Table 17).

A conservative estimate of hydrogen permeation loss rates has been predicted by A. L. Pitner (see Appendix F) as less than 0.044 percent of the hydrogen inventory in an RGSS sampler per day (at $100^{\circ} \mathrm{F}$ ). This loss rate would decrease at lower temperatures. For the 76 day RGS-058 aging test reported in Table 23, Pitner would predict the hydrogen loss at 7ess than 3.3 percent (resulting in a change in the hydrogen concentration from the expected value of 30.1 percent to 29.1 percent). This estimate is consistent with the maximum hydrogen loss of 2.9 percent determined above from the RGS-058 data, although the actual loss is probably significantly lower. 


\subsubsection{Sampler In-Leakage}

The maximum oxygen concentration measured was 0.054 percent for aging test RGS-058, and subtracting the 0.007 percent intrinsic oxygen measured for gas MIX\#1 (determined from control sample RGS-004) results in a 0.047 percent level of leaked oxygen. This oxygen should correspond to a leakage of $0.23 \mathrm{~mL}$ of air (at STP) over the 1829 hour test.

The significance of this amount of leakage depends on the quantity of sample gas; as the total quantity of sample gas decreases, the error percentage due to leakage increases. The FRD specifies a required sample "void fraction" (ratio of STP gas volume to solid/liquid volume) measurement accuracy of 2 percent (absolute). A 2 percent sample void fraction (SVF) would correspond to an STP gas volume of about $6 \mathrm{~mL}$ for a nearly full sampler; thus, this is the minimum quantity of retained gas that the FRD requires the RGSS to analyze with full accuracy.

A $0.23 \mathrm{~mL}$ quantity of leaked air has negligible effect on the sample void fraction determination for a nearly full sampler; however, it would comprise 3.8 percent of a $6 \mathrm{~mL}$ gas sample and would affect composition results. For example, if the sample gas is 30 percent hydrogen, then the hydrogen composition measurement error would be -1.2 percent - which is still within the FRD requirements (not including hydrogen seal permeation and MS measurement errors).

The previous description of the permeation $(0.9 \%)$ and measurement $( \pm 0.7 \%)$ errors assumed a worse case combination of these errors; however, statistically, the error band for the combination of these errors can be reduced from 1.6 percent to a \pm 1.1 percent error band for hydrogen. This leaves a 0.9 percent allowable error for air leakage, while still meeting the stringent 2 percent FRD accuracy requirement for hydrogen. Assuming a maximum of 50 percent hydrogen in tank gas samples, and an air leak rate constant with time, then this limit is reached in about 36 days.

\subsubsection{Sampler Out-Leakage}

To date, helium leak test measurements performed on fabricated retained gas samplers have averaged about $5 \times 10^{-7} \mathrm{~atm} / \mathrm{cc} / \mathrm{sec}$ at an internal pressure of 3 atmospheres. The specified maximum leak rate allowed for a retained gas sampler is $1 \times 10^{-6} \mathrm{~atm} / \mathrm{cc} / \mathrm{sec}$ at an internal pressure of 3 atmospheres; this would correspond to an out-leakage of about $0.086 \mathrm{~mL} /$ day (at STP).

Assuming the maximum allowed out-leakage of $0.086 \mathrm{~mL} /$ day and a 36 day hold time (see in-leakage considerations), the total volume of sample gas lost would be $3.1 \mathrm{~mL}$, or more than half the sample if the original gas volume was $6 \mathrm{~mL}$. This loss of sample gas might affect both sample void fraction and composition determinations, as will be discussed. 
The effect of sample gas out-leakage on sample void fraction determination will be examined first. For a given gas sample loss and $V_{s L}$ error, the SVF error increases with smaller initial gas sample and solid/liquid volume. The maximum error in the measurement of $V_{S L}$ during both RGSS proof testing and acceptance testing was less than $20 \mathrm{~mL}$. Starting with the minimum sample gas quantity of $6 \mathrm{~mL}$ (as previously discussed) and assuming that $V_{S L}$ can be measured to within $\pm 20 \mathrm{~mL}$ and that out-leakage is at the maximum rate for 36 days, then the 2 percent SVF accuracy requirement (FRD) would be met provided that $V_{\mathrm{SL}}$ is greater than $170 \mathrm{~mL}$.

Out-leakage of the sample gas itself would generally not seriously affect composition analysis unless there were a preferential leakage of certain constituent gases; there was no evidence of this effect observed in the long term RGS-058 test. However, the combination of out-leakage of sample gas and the in-leakage of air can seriously alter the sample gas composition measurement. Using spreadsheet software, the maximum hold time for an RGS sampler before testing was determined by assuming the worst case out-leakage rate of $0.086 \mathrm{~mL} /$ day and using the "measured" (assuming constant leak rate) air in-leakage rate of $0.23 \mathrm{~mL} / 76$ days $=3.03 \times 10^{-3} \mathrm{~mL} /$ day. Making these assumptions, then the FRD requirements for both sample void fraction and gas composition accuracy are met provided the maximum hold time for the sampler is 23 days or less, and the $V_{\mathrm{sL}}$ is measured at $150 \mathrm{~mL}$ or more. (The minimum $\mathrm{V}_{\mathrm{sL}}$ value is reduced from the previous determination because of the reduction in allowed hold time.)

It should be noted that the air in-leakage rate used in the above hold time determination is based on only two different sampler aging tests, RGS-57 and RGS-58 (assuming that aging for 1 week or longer provides more valid data than the remaining two shorter term tests). As funding priorities allow, it is recommended that additional long term aging tests be performed.

Based on this analysis, the authors recommend that the maximum storage time for samples be less than 23 calendar days at temperatures less than $100{ }^{\circ} \mathrm{F}$. However, if it is not possible to test a stored sampler within this time period, accuracy validation can be performed on a case by case basis depending on the measured gas concentrations and volume determinations.

\subsection{EXCEPTIONS TO ATP}

The ATP specified that exceptions and deviations from the ATP testing requirements should be documented in this ATR report. Allowed exceptions could include deletion of tests or specification of additional tests as agreed to by the cognizant test director. Throughout this ATR, changes from the ATP description have been identified as the specific tests were discussed. In this section, these exceptions and deviations from the ATP are summarized. 
The in situ gas chromatograph was not used in acceptance testing, which is relevant to Section 5.3 of the ATP.

For the Extractor Volume Measurement called out in Section 7.1.2 of both the ATP and ATR, Table 1 of the ATP was modified slightly changing the test procedure and reporting format for the ATR (see Table 3); the primary change was decreasing the "settling time" from 10 minutes to 3 minutes. Also, the RGSS line volume and cabinet volumes were measured using pressure drops and the perfect gas law.

In Section 7.2 of the ATP, four injection tests using two gas mixes were described and required. These four tests were performed as described, although minor changes were made in the test data sheet ("Sampler" changed to "Canister" for volume, temperature and pressure of the injection gas). Also, one control sample analysis for each type of gas used was determined to be adequate, so that (contrary to the ATP) control samples were not obtained for each injection test.

Many (24) additional injection tests were also performed that were not identified or described in the ATP. These additional tests were very helpful in demonstrating the capability of the RGSS to meet the requirements of the FRD.

For all injection tests only the $\mathrm{Hg}$ Pump method was used to determine gas quantity, instead of both the SPT and BT methods as suggested in the ATP.

In Section 7.3 of the ATP, simuluant extrusion tests are described; a number of changes were made in the tests actually performed from those described in the ATP. Gas composition analysis WAS performed, even though the ATP stated that it would not be. Although the ATP implies that six of these tests would be performed, two (ambient and $50{ }^{\circ} \mathrm{C}$ ) for each of the three conditions identified, only three tests were performed. Air and Carbopol were not used as simulants; air was not used because gas composition analysis was performed, and Carbopol was eliminated because of the outgassing problems it presented. Since Carbopol simulant was not used, the 2:1 dilution test was deleted. The three tests actually performed demonstrated proper operation and function of the complete RGSS, including sampler attachment and sample extrusion. The data sheet identified in the ATP was modified to eliminate the ASA and change several other features to better match the tests performed. Please compare the ATP data sheet with those given in Appendix C.

Additionally, four sampler aging tests were added to the acceptance test list which were not identified in the ATP. These tests allowed a determination that under normal conditions a sampler could be expected to retain its sample gas without compromising its composition or quantity for up to 76 days after sampling. 


\subsection{SUMMARY}

The RGSS was developed to provide an analysis of both gas quantity and gas composition of samples obtained from certain flammable gas waste tanks at Hanford. The acceptance tests and results described herein were performed to verify the compliance of the RGSS design and fabricated system with the functions and requirements specified in the FRD.

\subsection{Testing and Analys is Description}

Analysis of the data obtained during acceptance testing was performed using several different techniques. Gas composition analys is was performed with a mass spectrometer (MS) for insoluble gas composition, and with the ammonia solution analysis (ASA) technique to determine the ammonia content. Gas quantity analysis used three different techniques; the Backfill Technique (BT), the Hg Pump method and the Two Volume (TV) method.

Ammonia analysis with the ASA technique was performed by isolating a portion of the test gas in the RGSS 2nd Volume, and fully absorbing ammonia into a slightly acidic solution. The solution was removed and tested with an ion probe to determine the solution's ammonia concentration. The original concentration of ammonia gas in the test gas could then be calculated.

The Backfill Technique was performed after the test sample gas had been transferred to collection canisters for MS composition analysis. Using argon or air, the extractor was repressurized in steps; the data gathered was used with the perfect gas law to determine the bulk volume $\left(V_{s L}\right)$ of the solid and liquid portion of the test sample. The test sample's solid/liquid volume is essential for determining the ratio of sample gas to bulk sample volume, as required by the FRD. Also, $V_{S L}$ is essential for the Two Volume analysis determination of gas quantity and soluble gas vapor pressure.

The Hg Pump method simply transfers the test gas from the extractor to the known volumes on the collection side of the transfer pump. The quantity of gas transferred can be calculated using the perfect gas law. However, only insoluble gas is fully transferred, and soluble gas vapor pressure can complicate the analysis.

The Two Volume method consists of measuring the pressure and temperature of the sample gas, first in the extractor, and then again as the previously evacuated 2nd Volume is opened up to the extractor. The data gathered in these two volume conditions, along with $v_{s L}$ measured later allows the determination of the gas quantity and the soluble gas vapor pressure. It should be noted that the TV method relies on the approximation that the soluble gas vapor pressure doesn't change significantly when the system volume expands to include the 2 nd Volume. This may not be a good approximation in the case of ammonia, as has been pointed out by Shekarriz and Norton (PNLFGP: 091595). This subject is discussed in Appendix G. 


\subsection{Acceptance Test Results}

Twenty eight gas injection tests were performed, with the results used for both gas composition analysis and gas quantity analysis (limited to the $\mathrm{Hg}$ Pump Method). A gas injection test was conducted by putting gas directly into the extractor through the RGSS dilution port, rather than by using a sampler; this was done either with the system dry, or with a prototypic quantity of degassed water (to simulate bulk waste) already in the extractor. Injection tests were simpler and less costly to run than the full simulation tests performed at the end of acceptance testing.

One of three types of gas was used in each injection test; these gas types included two mixes and relatively pure (99.95\%) argon. Gas MIX\#1 contained ammonia $(5.0 \%)$, argon $(24.9 \%)$, hydrogen $(30.3 \%)$ and nitrogen (39.8\%); MIX\#2 contained nitrogen $(30.0 \%)$, nitrous oxide $(30.8 \%)$ and helium $(39.2 \%)$. Using two separate gas mixes to simulate expected waste gas components allows the separation of hydrogen and nitrous oxide, which together would be an explosive mixture.

All MS gas composition analyses performed for these test conditions were accurate within the FRD requirements, except for ammonia composition. Ammonia measurement by the ASA method (performed for seven tests) also failed to meet the FRD requirement; al though the average of the ASA results was 3.17 percent (where 5.02 percent was expected), four of the seven tests had ammonia compositions below 3 percent and failed to meet the FRD requirement of \pm 2 percent absolute accuracy. However, the ASA results were more accurate than the MS ammonia results, which averaged 1.6 percent ammonia.

All injection test gas quantity determinations using the $\mathrm{Hg}$ Pump method were within the requirements of the FRD.

Three full simulation tests were performed. For each test, a sampler was filled with a simulation gas (argon or helium) and degassed water. The sampler was attached to the RGSS extractor, and the simulants extruded into the previously evacuated extractor. The 2 nd Volume was then connected with the extractor, and isolated (however, no ASA was performed). The simulant gas was transferred to the collection canister and the gas analyzed for composition. The BT procedure was then performed.

The MS composition results for these three tests were all within the FRD requirements. The BT determination of the solid/liquid volume was correct to within $3.5 \mathrm{~mL}$ for $\mathrm{V}_{\mathrm{SL}}$ nominally equal to $285 \mathrm{~mL}$ (equivalent to approximately a 1 percent error). The gas quantities determined with the $\mathrm{Hg}$ Pump method were all with in the FRD requirement, although the vapor pressure determination was too high by roughly 25 percent. Also, the gas quantities determined with the Two Volume method were all within the FRD requirement, except that one test required correction for air outgassing (using oxygen as a tracer, see Appendix D). The vapor pressure determination using the Two Volume method was quite accurate (average error $=1.6$ percent). 
Sampler "aging" tests were performed in which four different samplers were pressurized with a 30 percent hydrogen gas (MIX\#1) at or less than atmospheric pressure. The samplers were allowed to sit for aging times of between 24 to 1829 hours (76 days); then the composition of the sampler gases was determined.

A conservative estimate of hydrogen loss rates has been made by $A . L$. Pitner as less than 0.044 percent of the hydrogen inventory in an RGSS sampler per day (at $100^{\circ} \mathrm{F}$ ). This loss rate would decrease at lower temperatures. For the 76 day RGS-058 aging test reported in Table 23, Pitner would predict the hydrogen loss at less than 3.3 percent, resulting in a change in the hydrogen concentration from the expected value of 30.1 percent to 29.1 percent. The measured hydrogen concentration for RGS-058 was 30.5 percent, with an error band of \pm 0.6 percent; this result suggests minimal hydrogen loss and some data scatter. In addition, a worst case hydrogen loss (accounting for error bars) was determined from the RGS-058 data as 2.9 percent, which is also within the Pitner estimate.

An analysis of the measured oxygen level of 0.054 percent for the long term RGS-058 aging test was made. It appears that air in-leakage and sample out-leakage may pose a problem for lengthy storage of RGS samplers prior to testing. Combining sampler leakage with possible hydrogen permeation and measurement error considerations, it is concluded that the FRD accuracy requirements might be compromised for sampler storage exceeding 23 calender days, or at temperatures higher than $100^{\circ} \mathrm{F}$.

\subsection{Conclusions}

Acceptance testing of the RGSS demonstrated that the system meets all of the functions and requirements specified in the FRD except for ammonia analysis accuracy. It is recommended that this first generation system be deployed to the 222-S hot cell facility and that testing of authentic waste samples be initiated. All of the testing capability of the system should be used, including ASA ammonia analysis; although the ASA didn't meet the FRD requirements, it still provides the best data available at this time for ammonia composition.

The analysis techniques that produce data with the greatest confidence are:

- Insoluble Gas Quantity:

- Bulk Volume $\left(V_{s L}\right)$ :

- Soluble Gas Vapor Pressure:

- Ammonia Concentration:
Hg Pump Method

Backfill Technique

Hg Pump Method

ASA 
Additional study of the ASA ammonia measurement technique will be performed in the future. Efforts will center on determining if the ammonia loss is due to extra stainless steel surface area not present during proof testing, or due to the extractor plastic splash shield (or other potential ammonia absorbers). It is likely that the ASA method can be improved to produce results within the FRD requirements using essentially the same hardware. Until this goal is achieved, reported ammonia concentration data obtained with the RGSS will be footnoted to indicate the RGSS noncompliance with the FRD requirements reported here.

The Two Volume method provided the best data for measuring water vapor pressure during acceptance testing. However, as discussed in Appendix $G$, when ammonia is present in the waste, the error associated with the TV method of measurement of the ammonia gas pressure may be quite large (up to a factor of two). Thus, the $\mathrm{Hg}$ Pump method is recommended for authentic waste sample measurements of soluble gas pressure despite the approximate 25 percent errors encountered in acceptance testing. This recommendation is conditional on the quantity of ammonia measured; when ammonia vapor pressure is small compared to water vapor pressure (less than 25 percent), it is expected that the TV method would provide better results, based on acceptance test data.

As also discussed in Appendix G, the Two Volume method may provide an excellent method for characterizing ammonia properties in waste samples, provided that ammonia vapor pressure can be accurately measured using improved ASA or Hg Pump techniques, and there are no other soluble gases present in significant quantity.

The sampler aging tests performed demonstrated that a delay in RGSS testing of up to 18 calender days after a waste sample is obtained can be tolerated without significant adverse affects on the accuracy of the gas composition results - provided that the sampler is stored at temperatures of less than $100^{\circ} \mathrm{F}$.

\subsection{ACKNOWLEDGEMENTS}

The authors wish to express their appreciation to their management for the support and guidance received throughout RGSS acceptance test preparation and performance. Also greatly appreciated was the dedicated and insightful system fabrication and maintenance support provided by $M$. E. Dahl and many other Equipment Development personnel.

In order to allow familiarization with operation of the RGSS by the receiving group (Process and Development), B. E. Hey performed several of the acceptance tests (see Appendix E); we gratefully acknowledge this contribution. 
TABLE 1

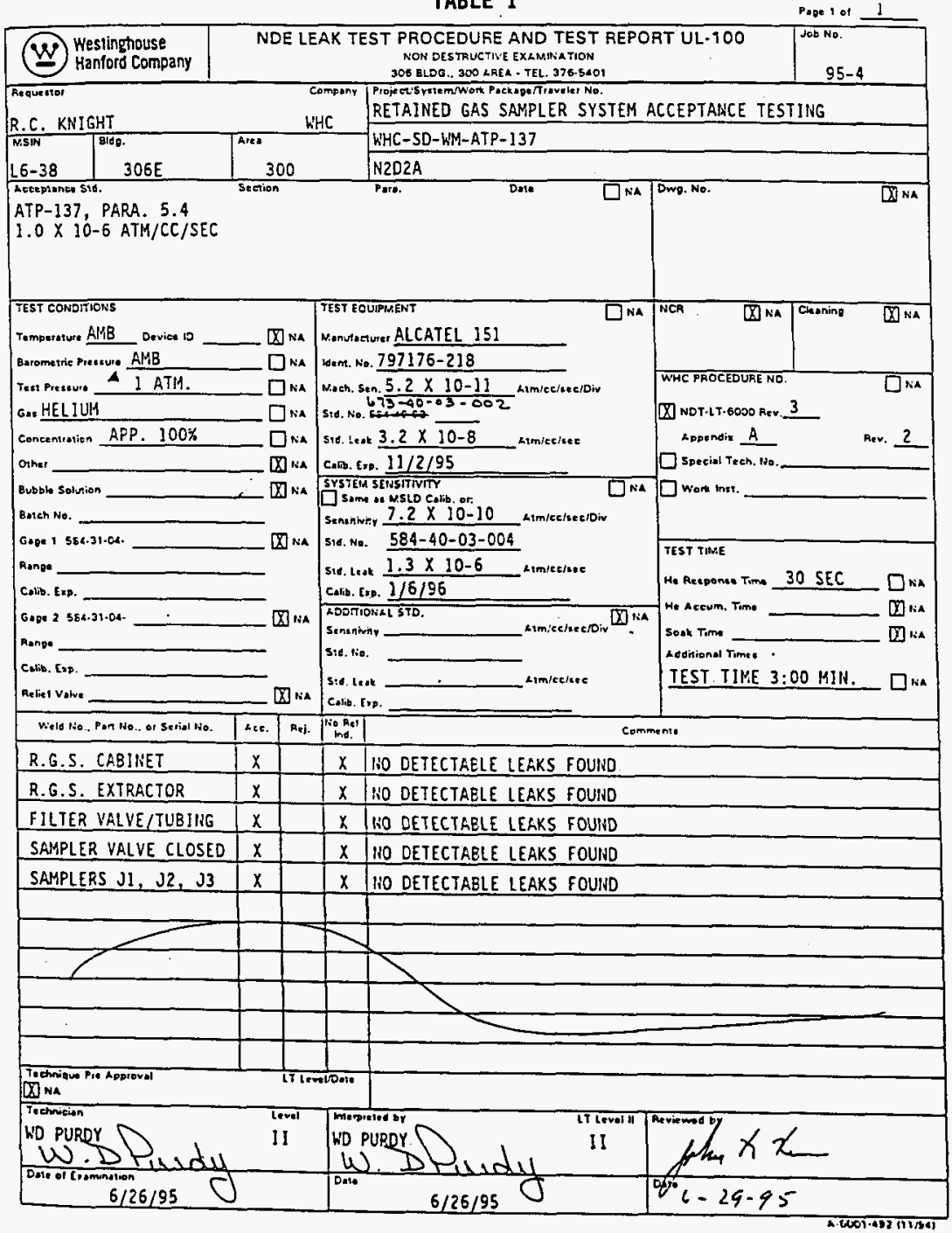


TABLE 2

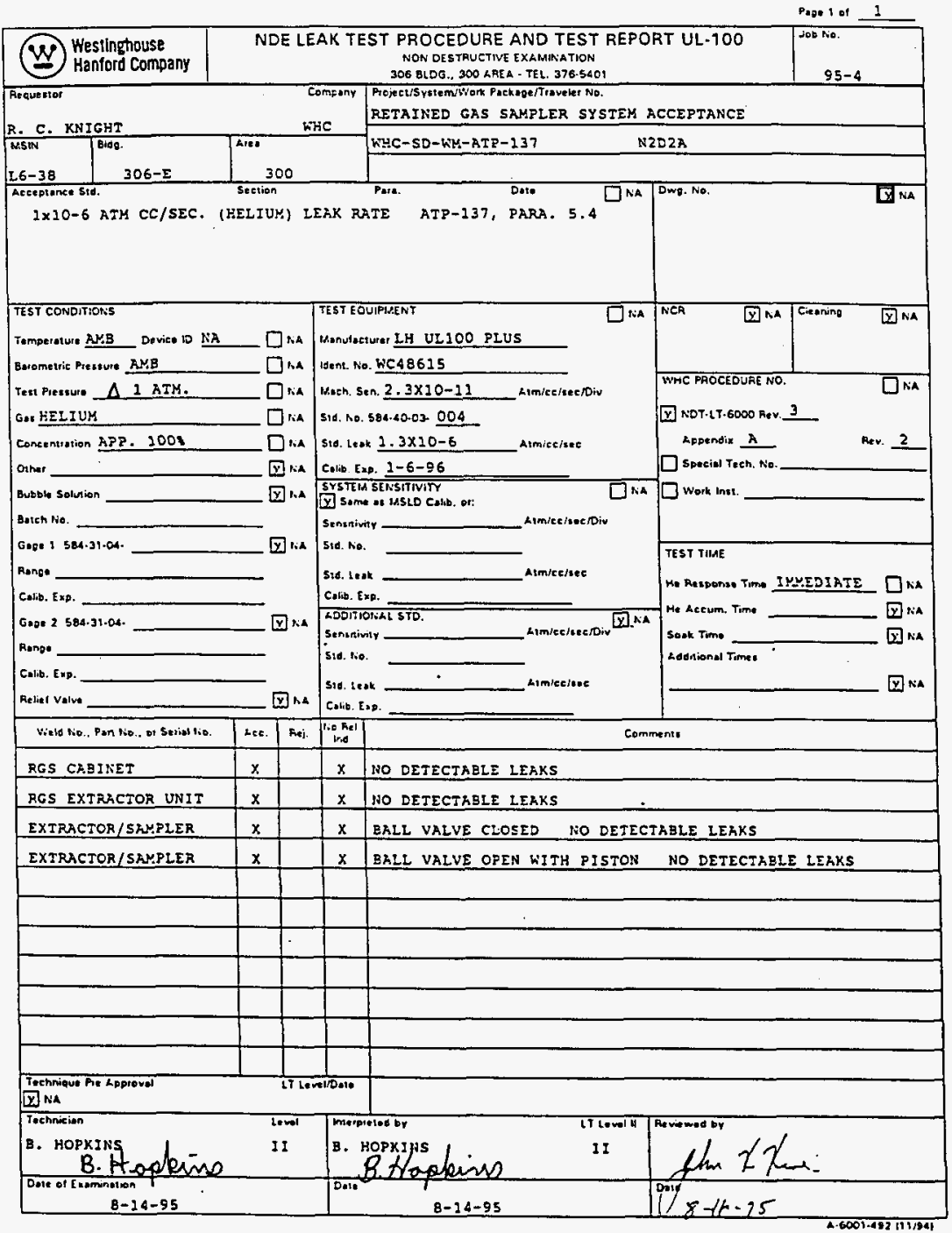


TABLE 3

\section{EXTRACTOR VOLUME MEASUREMENT TABLE}

- Use argon as working mediun. Evacuate lines, 2nd volume and Extractor. Fill lines to known pressure (recomend about 750 Torr). Record pressure temperature data; then open valve to znd Volume, record dats; then open valve to Extractor and record data. Allow 3 minutes for "settling" ofter each valve opening before taking pressure measurement. Temperature at pressure measurement time should be recorded.

- $\quad P 1$ is starting pressure in Lines; $P 2$ is pressure 2nd Volume + Lines; 93 is pressure in Extractor + lines + 2nd volume.

TEST DATE 6-27-95 TEST DESCRIPTION: Acceptance Test -

Test Performer N.S. Corvon $320.0 \mathrm{nLC}$ Measured and Volume $=230.0 \mathrm{~mL}$ Initial Uolume ineasurements

\begin{tabular}{|c|c|c|c|c|c|c|c|c|}
\hline $\begin{array}{c}\text { TEST } \\
\#\end{array}$ & $\begin{array}{l}\text { Pl } \\
\text { Press. } \\
\text { (Torr) }\end{array}$ & $\begin{array}{l}\text { Temp. } \\
\left({ }^{\circ} \mathrm{C}\right) \\
\mathrm{B}^{\mathrm{B}} \mathrm{Pl}\end{array}$ & $\begin{array}{l}\text { P2 } \\
\text { Press. } \\
\text { (Torr) }\end{array}$ & $\begin{array}{l}\text { Temp. } \\
\left({ }^{\circ} \mathrm{C}\right) \\
0 \mathrm{P} 2\end{array}$ & $\begin{array}{l}\text { P3 } \\
\text { Press. } \\
\text { (Torr) }\end{array}$ & $\begin{array}{l}\text { Temp. } \\
\left({ }^{\circ} \mathrm{C}\right) \\
0 \mathrm{P3}\end{array}$ & $\begin{array}{l}\text { Line } \\
\text { Volume } \\
\text { (cc) }\end{array}$ & $\begin{array}{l}\text { Extractor } \\
\text { Volume } \\
\text { (cc) }\end{array}$ \\
\hline 1 & 8721.4 & 20.9 & 294.2 & 20.9 & 84.1 & 21.0 & 220.4 & 1350.0 \\
\hline 2 & 706.0 & 21.2 & 288.3 & 21.2 & 82.4 & 21.3 & 220.9 & 1351.5 \\
\hline 3 & 754.4 & 21.8 & 307.8 & 21.8 & 87.8 & 21.8 & 220.5 & 1354.7 \\
\hline 4 & 7494 & 22.5 & 306.0 & 22.5 & 87.5 & 22.6 & 220.8 & 1350.6 \\
\hline 5 & 726.0 & $23.0^{\circ}$ & 296.8 & 23.1 & 85.0 & 23.1 & 221.3 & 1348.8 \\
\hline 6 & 724.4 & 23.2 & 235.9 & 23.2 & 84.8 & 23,2 & 221.0 & 1346.2 \\
\hline 7 & $730 . C_{2}$ & 23.3 & 298.6 & 23.3 & 85.5 & 23.3 & 221.2 & 1348.8 \\
\hline 8 & 723.2 & 23.4 & 295.4 & 23.4 & 845 & 23.4 & 221.0 & 1350.2 \\
\hline 9 & 736.4 & 23.5 & 300.8 & 23.5 & 86.1 & 23.5 & 221.0 & 1349.0 \\
\hline 10 & 748.8 & 23.5 & 305.8 & 23.5 & 87.6 & 23.5 & 220.9 & 1347.3 \\
\hline & & & & & & & & \\
\hline & & & & & & & & \\
\hline & & & & & & & & \\
\hline
\end{tabular}

AVERAGE EXT. VOLUME (mL) 1349.7

STANDARD DEV. (mL) 2.1

Test Witnesses:

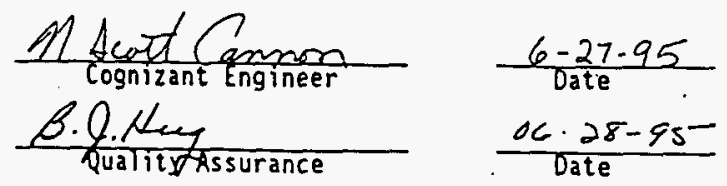




\section{TABLE 4}

CABINET VOLUME MEASUREMENTS

Uses Line Volume $(221.3 \mathrm{~mL})$ as starting volume

$V E=$ Volume between $V_{B}$ ives $B$ and $E \quad V F=$ Volume between Volves $E$ and $F$

$V H=$ Volume between Valves $F$ and $H$

VHI = Volume betueen Valves $H I$ and $\$ 1$ canister

$V H 2=$ Volume between Valves $H 2$ and $J 2$ canister

$V_{H 3}=$ Volume between Valves $\mathrm{H3}$ and $\mathrm{J3}$ canister

VJ1 = Volume of $\$ 1$ Canister

$V \sqrt{2}=$ Volume of 12 Canister

VJ3 $=$ Volume of $\mathrm{J3}$ Canister

Vsamp $=V H+V H 1+V J 1$

General Calculation: $\quad V x=(P 1-P 2) / P 2 * v s$

$V L=221.3 \mathrm{cc}$

\begin{tabular}{|c|c|c|c|c|c|c|c|c|c|c|}
\hline Test & Date & $\begin{array}{l}\text { Start } \\
\text { Press. } \\
\text { (Torr) }\end{array}$ & $\begin{array}{c}\text { Dump to } \\
\text { (Torr) }\end{array}$ & $\begin{array}{c}\text { Cal. } \\
\text { VE } \\
(c c)\end{array}$ & $\begin{array}{c}\text { Dup to } \\
\text { (torr) }\end{array}$ & $\begin{array}{c}\text { Cal. } \\
\text { VF } \\
(C C)\end{array}$ & $\begin{array}{c}\text { Dump to } \\
\text { Hi } \\
\text { (Torr) }\end{array}$ & $\begin{array}{c}\text { Cal } \\
\text { VH } \\
(c C)\end{array}$ & $\begin{array}{c}\text { Dump to } \\
\text { Through } \\
\text { H1 } \\
\text { (Torr) }\end{array}$ & $\begin{array}{l}\text { Cal. } \\
\text { VHI } \\
\text { (cc) }\end{array}$ \\
\hline $\begin{array}{l}1 \\
2 \\
3 \\
4\end{array}$ & $\begin{array}{l}\overline{06-29-95} \\
06-29-95 \\
06-29-95 \\
06-29-95\end{array}$ & $\begin{array}{l}686.1 \\
648.1 \\
417.7 \\
792.5\end{array}$ & $\begin{array}{l}645.4 \\
609.7 \\
393.0 \\
745.9\end{array}$ & $\begin{array}{l}13.96 \\
13.94 \\
13.91 \\
13.83\end{array}$ & $\begin{array}{c}\text { NA } \\
591.8 \\
381.4 \\
724.0\end{array}$ & $\begin{array}{l}\text { NA } \\
7.12 \\
7.15 \\
7.11\end{array}$ & $\begin{array}{c}\text { NA } \\
549.4 \\
354.0 \\
672.3\end{array}$ & $\begin{array}{c}\text { MA } \\
18.70 \\
18.76 \\
18.63\end{array}$ & $\begin{array}{l}\text { NA } \\
544.2 \\
350.6 \\
665.8\end{array}$ & $\begin{array}{l}\text { NA } \\
2.49 \\
2.53 \\
2.55\end{array}$ \\
\hline AVERAGE & & & & 13.91 & & 7.13 & & 18.70 & & 2.52 \\
\hline
\end{tabular}

\begin{tabular}{|c|c|c|c|c|c|c|c|c|c|c|}
\hline $\begin{array}{c}\text { Dump to } \\
\text { Through } \\
\text { H2 } \\
\text { (Torr) }\end{array}$ & $\begin{array}{l}\text { Cal. } \\
\text { vHz } \\
\text { (cc) }\end{array}$ & $\begin{array}{c}\text { Dump to } \\
\text { Through } \\
\text { H3 }\end{array}$ & $\begin{array}{l}\text { Cal : } \\
\text { VHi3 } \\
(\mathrm{CC})\end{array}$ & $\begin{array}{c}\text { Dump in } \\
\text { to Can. } \\
\mathrm{J} 1\end{array}$ & $\begin{array}{c}\text { Cal. } \\
\text { J1 } \\
\text { (cc) }\end{array}$ & $\begin{array}{l}\text { Dump in } \\
\text { to Can. } \\
\mathrm{J} 2\end{array}$ & $\underset{\text { Jal }}{\mathrm{Ca}}$ & $\begin{array}{c}\text { Dump in } \\
\text { to Can. } \\
\sqrt{3}\end{array}$ & $\begin{array}{c}\mathrm{Cal} . \\
\mathrm{J3} \\
(\mathrm{CC})\end{array}$ & $\begin{array}{l}\text { Vsamp } \\
\text { (d1) } \\
\text { (cC) }\end{array}$ \\
\hline $\begin{array}{l}\text { NA } \\
539.0 \\
347.3 \\
659.5\end{array}$ & $\begin{array}{l}\text { NA } \\
2.54 \\
2.51 \\
2.52\end{array}$ & $\begin{array}{l}\text { NA } \\
533.9 \\
344.1 \\
653.4\end{array}$ & $\begin{array}{l}\text { NA } \\
2.54 \\
2.48 \\
2.48\end{array}$ & $\begin{array}{l}\text { NA } \\
465.4 \\
299.9 \\
569.6\end{array}$ & $\begin{array}{c}\text { NA } \\
39.54 \\
39.59 \\
39.49\end{array}$ & $\begin{array}{l}\text { NA } \\
412.0 \\
265.4 \\
504.3\end{array}$ & $\begin{array}{c}\text { NA } \\
39.94 \\
40.07 \\
39.87\end{array}$ & $\begin{array}{c}\text { NA } \\
370.3 \\
238.5 \\
453.2\end{array}$ & $\begin{array}{c}\text { NA } \\
39.20 \\
39.28 \\
39.21\end{array}$ & $\begin{array}{l}\text { NA } \\
60.7 \\
60.9 \\
60.7\end{array}$ \\
\hline AVERAGE = & 2.52 & & 2.50 & & 39.54 & & 39.96 & & 39.23 & 60.76 \\
\hline
\end{tabular}


TABLE 5

DETERMINATION OF NEW LINE VOLUME (7-26-95)

\begin{tabular}{|c|c|c|c|c|c|}
\hline \multirow[b]{2}{*}{ Gas } & Volume & 320.64 & $c c$ & \multirow[b]{2}{*}{$\begin{array}{l}\text { Temp. } \\
\text { (C) }\end{array}$} & \multirow[b]{2}{*}{$\begin{array}{l}\text { Calcul. } \\
\text { Line Vol. } \\
\text { (cc) }\end{array}$} \\
\hline & $\begin{array}{l}\text { 2nd Vol } \\
\text { Press } \\
\text { (KPa) }\end{array}$ & $\begin{array}{l}\text { Start } \\
\text { Line } \mathbf{P} \\
(\mathrm{KPa})\end{array}$ & $\begin{array}{c}\text { Combined } \\
\text { Press } \\
\text { (KPa) }\end{array}$ & & \\
\hline \multirow[t]{2}{*}{$\begin{array}{l}\text { AIr } \\
\text { Argon } \\
\text { Argon } \\
\text { AIr } \\
\text { AIr } \\
\text { Argon } \\
\text { Argon } \\
\text { AIr } \\
\text { AIr } \\
\text { AIr }\end{array}$} & $\begin{array}{r}99.67 \\
99.26 \\
61.18 \\
99.65 \\
61.33 \\
100.10 \\
61.70 \\
99.46 \\
61.21 \\
37.67\end{array}$ & $\begin{array}{l}0.024 \\
0.022 \\
0.021 \\
0.027 \\
0.018 \\
0.020 \\
0.025 \\
0.030 \\
0.030 \\
0.023\end{array}$ & $\begin{array}{l}61.40 \\
61.18 \\
37.71 \\
61.33 \\
37.77 \\
61.70 \\
38.01 \\
61.21 \\
37.67 \\
23.20\end{array}$ & $\begin{array}{l}21.6 \\
21.7 \\
21.7 \\
21.8 \\
21.7 \\
21.7 \\
21.7 \\
21.8 \\
21.8 \\
21.6\end{array}$ & $\begin{array}{l}199.85 \\
199.57 \\
199.56 \\
200.34 \\
200.01 \\
199.56 \\
199.84 \\
200.37 \\
200.37 \\
199.99\end{array}$ \\
\hline & . & & & $\underset{\text { STD }}{\operatorname{AVERAGE}}$ & $\begin{array}{r}199.95 \\
=\quad 0.31\end{array}$ \\
\hline
\end{tabular}

TABLE 6

DETERMINATION OF NEW EXTRACTOR VOLUME (8-15-95)

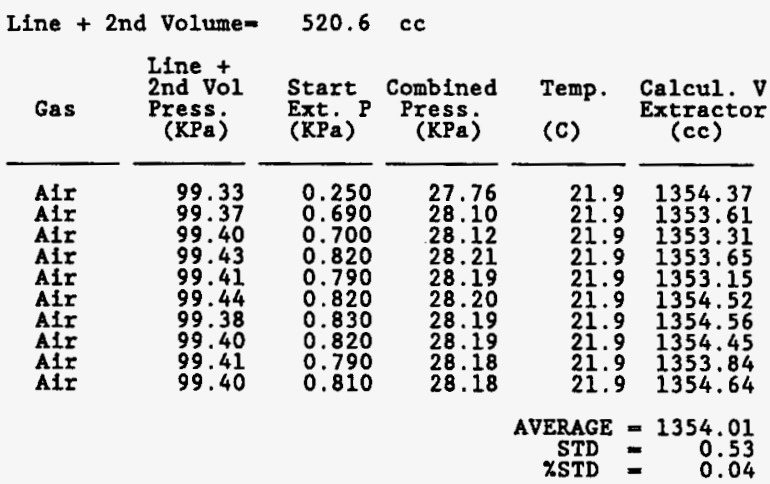




\section{EXTRACTOR/SAMPLER INTEGRATION TEST}

- Using air as working medium, fill sampler to known pressure and evacuate the Extractor/2nd volume. Perform SPT testing to verify proper functioning of the RGSS, and that volumes have been correctly measured. Allow 10 minutes for "settling" after each valve opening before taking pressure measurement. Temperature at pressure measurement time should be recorded.

- P1 is starting pressure in 2nd volume, P2 is resulting pressure in Extractor.

TEST DATE $\frac{7.14 .95}{1}$ TEST DESCRIPTION: $\frac{\text { Integration Test }}{N_{0} \text { p }}$ Test Performer C Kungt

\begin{tabular}{|c|c|c|c|c|c|c|}
\hline \multicolumn{3}{|c|}{$\begin{array}{l}\text { SAMPLER ID } \# 1 \\
\text { SAMPLER PRESSURE } 754.8 \\
\text { (WORKING GAS = AMBIENT AIR) }\end{array}$} & \multicolumn{2}{|c|}{$\begin{array}{l}\text { SAMPLER VOLUME } \\
\text { r) TEMPERATURE LIT }\end{array}$} & \multicolumn{2}{|c|}{$\frac{314.63}{\operatorname{sen} 21-25.1}\left({ }^{\circ} \mathrm{C}\right)$} \\
\hline $\begin{array}{l}\text { TEST } \\
\text { TYPE }\end{array}$ & $\begin{array}{l}\text { TEST } \\
\text { STEP }\end{array}$ & TIME & $\begin{array}{l}\text { TEMP. } \\
\left({ }^{\circ} \mathrm{C}\right)\end{array}$ & $\begin{array}{c}\text { Sensor } 1 \\
{[1000]} \\
\text { (Torr) }\end{array}$ & $\begin{array}{c}\text { Sensor } 2 \\
\text { [100] } \\
\text { (Torr) }\end{array}$ & $\begin{array}{c}\text { Sensor } 3 \\
\text { [10] } \\
\text { (Torr) }\end{array}$ \\
\hline \multirow[t]{7}{*}{ SPT } & Zero & $2: 31 \mathrm{p}$ & 25.1 & .05 & 006 & .006 \\
\hline & Leak Test Start & $2: 32$ & -25.1 & $05^{\circ}$ & 006 & .006 \\
\hline & Leak Test End & $2: 42$ & 25.1 & $O L$ & .017 & .017 \\
\hline & Extractor Start & $9: 46$ & 25,1 & 20.37 & - & $\sim$ \\
\hline & Extractor End & $2: 56$ & 95.1 & 20.38 & - & - \\
\hline & 2nd $V_{0} l$. Start & 9.52 & 25.1 & 16.95 & 16.942 & - \\
\hline & 2nd $v_{0} r$. End & $3: 07$ & 25.1 & 16.96 & 16.956 & - \\
\hline
\end{tabular}

AVERAGE EXT. VOLUME (mL) 1570.6 2ND VOLUME (mL) 390.0

Test Witnesses: Q.t Cannore $\frac{\text { B. R. Nuy }}{\text { Quatity dessurance }}$ 


\section{TABLE 8}

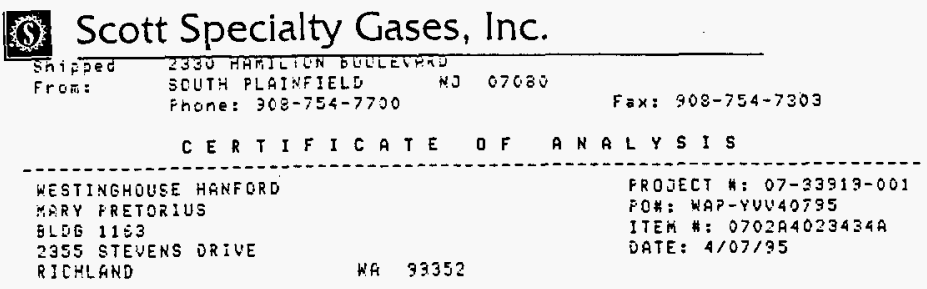

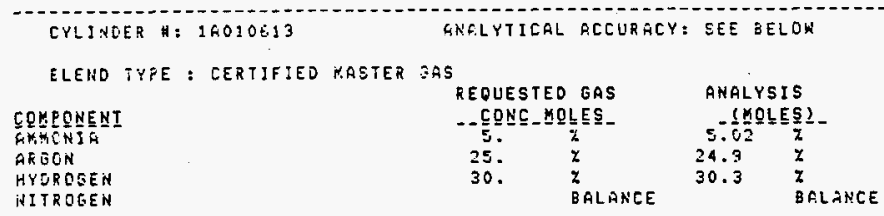

Anbitarily descgnated as $m 1 x \# 1$ (N)

\footnotetext{
ANELYTICAL GCCURACY $+1-1 Z$ FOR ANALYTICAL GCCURACY $+1-2 X$ FOR

GRGON \& HYOEOGEN ATHON1A
}

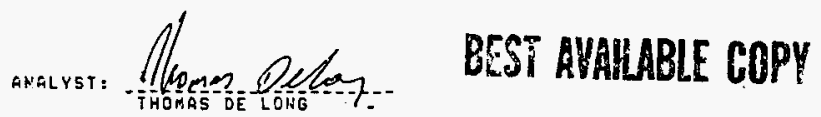

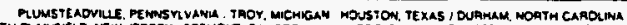

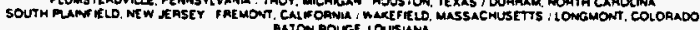


TABLE 9

RECEIVEW

Scott Specialty Gases, Inc.

$A P R 11393$

hCCGINTS PAY:FLE

2600 CAJON BOULEVARD, SAN EEFNARDINO. CA 92419 $\quad$ (909) 887-2571 $\quad$ Fax: (909) 887.0549

C ER T I E I C A T E OF A N A L Y S I S

WESTINGHOUSE HANFORD

ELDG 1163

2355 STEVENS DRIVE

RICHLAND
WA 99352
FROJECT \#: 02-37224-001

PO\#: WAP-YVN407950

ITEM \# : 0202N3016714A

DATE : $4 / 03 / 95$

CYLINDER \# : X94572J

FILL PRESSURE: 1900 PSIG

BLEND TYPE : CERTIFIED MASTER GAS

COMPONENT

NITROGEN

NITROUS OXIDE

HELIUM

\section{ANALYTICAL ACCURACY: $+/-2$}

REQUESTED GAS CONC MOLES

30.7
30 . $t$ BALANCE
ANALYSIS

30.0 (MOLES)
$30.8 \quad \vdots$
30.8 EALANCE

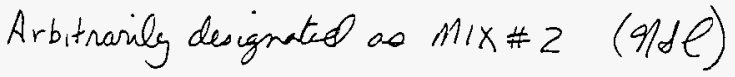

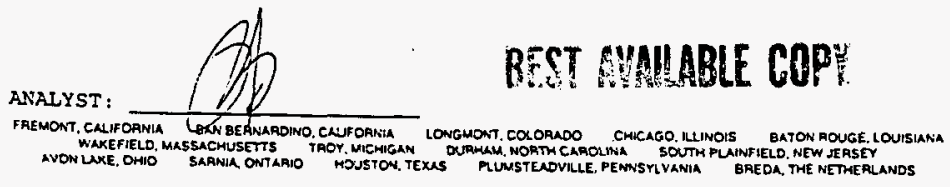




\section{$H E=\ldots$ \\ WHC- \$O-WM-ATR-137 \\ INJECTION TEST DATA SHEET \\ Page it3}

TEST DATE $6-29-95$ Test Performer N.S. CanNo

GAS MIX ID $M I X \# 2\left(\mathrm{~N}_{2} \mathrm{O}+\right) \quad$ CANISTER TEMP. $29^{\circ} \mathrm{C}$

CANISTER VOL. (mL) 41.3

CANISTER PRESS. $102.6 \mathrm{KPa}$ (769.2 Torr)

\begin{tabular}{|c|c|c|c|c|c|c|c|c|}
\hline $\begin{array}{l}\text { TEST } \\
\text { TYPE }\end{array}$ & \multicolumn{2}{|l|}{$\begin{array}{l}\text { TEST } \\
\text { STEP }\end{array}$} & $\begin{array}{l}\text { TIME } \\
(P M)\end{array}$ & $\begin{array}{l}\text { TEMP. } \\
\left({ }^{\circ} \mathrm{C}\right)\end{array}$ & $\begin{array}{l}\text { Sensor } 1 \\
{[1000 \mathrm{~T}]} \\
(\mathrm{KPa})\end{array}$ & \multicolumn{2}{|c|}{$\begin{array}{l}\text { Sensor } 2 \\
{[100 \mathrm{~T}]} \\
(\mathrm{KPa})\end{array}$} & $\begin{array}{c}\text { Sensor } 3 \\
{[10 \mathrm{~T}]} \\
(\mathrm{KPa}) \\
\end{array}$ \\
\hline \multirow[t]{7}{*}{ SPT } & \multicolumn{2}{|l|}{ Zero } & $4: 29$ & 26.7 & 0.04 & \multicolumn{2}{|c|}{0.013} & 0.0120 \\
\hline & \multicolumn{2}{|c|}{ Leak Test Start } & $4: 29$ & 26.7 & 0.04 & \multicolumn{2}{|c|}{0.013} & 0.0120 \\
\hline & \multicolumn{2}{|c|}{ Leak Test End } & $4: 35$ & 26.7 & 0.06 & \multicolumn{2}{|c|}{0.028} & 0.0279 \\
\hline & \multicolumn{2}{|c|}{ Extractor Start } & $4: 36: 20$ & 26.7 & 2.64 & \multicolumn{2}{|c|}{2.666} & OFF $\leq$. \\
\hline & \multicolumn{2}{|c|}{ Extractor End } & $4: 43$ & 26.7 & 2.64 & \multicolumn{2}{|c|}{2.667} & OFF $\mathrm{S}$. \\
\hline & \multicolumn{2}{|c|}{ 2nd Vol. Start } & $4: 43: 30$ & 26.7 & 2.21 & \multicolumn{2}{|c|}{2.239} & OfF $S$. \\
\hline & \multicolumn{2}{|c|}{ 2nd Vol. End } & $4: 52$ & 26.8 & 2.22 & \multicolumn{2}{|c|}{ 2. 244} & OFF $S$. \\
\hline $\begin{array}{l}\text { TEST } \\
\text { TYPE }\end{array}$ & $\begin{array}{l}\text { Solution } \\
\text { Volume } \\
\text { (mL) }\end{array}$ & $\begin{array}{l}\text { Mix } \\
\text { Time }\end{array}$ & $\begin{array}{l}\text { 2nd V } \\
\text { TEMP. } \\
\left({ }^{\circ} \mathrm{C}\right)\end{array}$ & $\begin{array}{c}\text { 2nd VOL. } \\
\text { Pressure } \\
\text { (KPa) }\end{array}$ & \multicolumn{2}{|c|}{$\begin{array}{l}\text { ANALYSIS } \\
\text { DATE }\end{array}$} & $\begin{array}{l}\text { Probe } \\
\text { Conc. } \\
(\mathrm{m} / \mathrm{cc})\end{array}$ & $\% \mathrm{NH}_{3}$ \\
\hline $\mathrm{NH}_{3}$ & & & & . & & & & \\
\hline
\end{tabular}

Hg PUMP INSOLUBLE EXTRACTOR GASES TO COLLECTION CANISTERS.

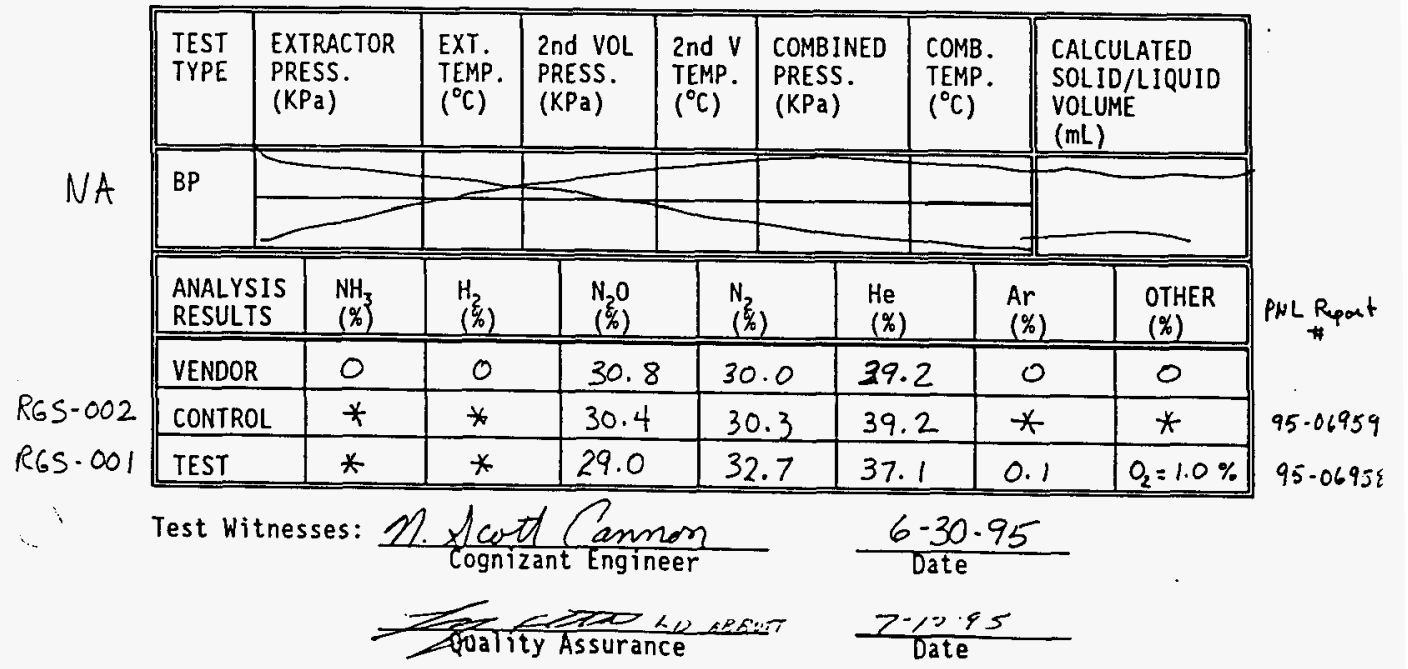

* Less than $0.1 \%$ 


\section{INJECTION TEST DATA SHEET Page 14}

TEST DATE $6-30-95$ Test Performer N.S. Cannow

GAS MIX ID MIX \#2

CANISTER VOL. (mL) 41.3
CANISTER TEMP.

CANISTER PRESS. $103.97 \mathrm{KPa}(779.8 \mathrm{TON})$

\begin{tabular}{|c|c|c|c|c|c|c|c|c|}
\hline $\begin{array}{l}\text { TEST } \\
\text { TYPE }\end{array}$ & \multicolumn{2}{|l|}{$\begin{array}{l}\text { TEST } \\
\text { STEP }\end{array}$} & $\begin{array}{l}\text { TIME } \\
\text { AM } \\
\end{array}$ & $\begin{array}{l}\text { TEMP. } \\
\left({ }^{\circ} \mathrm{C}\right) \\
T C * 2 \\
\end{array}$ & \multicolumn{2}{|c|}{$\begin{array}{c}\text { Sensor }] \\
{[1000 \mathrm{~T}]} \\
(\mathrm{KPa})\end{array}$} & $\begin{array}{c}\text { Sensor } 2 \\
{[100 \mathrm{~T}]} \\
(\mathrm{KPa})\end{array}$ & $\begin{array}{c}\text { Sensor } 3 \\
{[10 \mathrm{~T}]} \\
(\mathrm{KPa}) \\
\end{array}$ \\
\hline \multirow[t]{7}{*}{ SPT } & \multicolumn{2}{|l|}{ Zero } & $10: 10$ & 52.7 & \multicolumn{2}{|c|}{0.05} & 0.002 & 0.002 \\
\hline & \multicolumn{2}{|c|}{ Leak Test Start } & $10: 14$ & 52.7 & \multicolumn{2}{|c|}{0.05} & 0.003 & 0.003 \\
\hline & \multicolumn{2}{|c|}{ Leak Test End } & $10: 22$ & 52.7 & \multicolumn{2}{|c|}{0.05} & 0.009 & 0.009 \\
\hline & \multicolumn{2}{|c|}{ Extractor Start } & $10: 23$ & 52.7 & \multicolumn{2}{|c|}{2.76} & 2.777 & OFF $S$. \\
\hline & \multicolumn{2}{|c|}{ Extractor End } & $10: 34$ & 52.7 & \multicolumn{2}{|c|}{2.77} & 2.782 & OFF $S$. \\
\hline & \multicolumn{2}{|c|}{ 2nd Vol. Start } & $10: 34: 15$ & 52.7 & \multicolumn{2}{|c|}{2.33} & 2.340 & OFF. $S$ \\
\hline & \multicolumn{2}{|c|}{ 2nd Vol. End } & $10: 45$ & 52.6 & \multicolumn{2}{|c|}{2.34} & 2.347 & OFF $S$. \\
\hline $\begin{array}{l}\text { TEST } \\
\text { TYPE }\end{array}$ & $\begin{array}{l}\text { Solution } \\
\text { Volume } \\
(m L)\end{array}$ & $\begin{array}{l}\text { Mix } \\
\text { Time }\end{array}$ & $\begin{array}{l}\text { 2nd V } \\
\text { TEMP. } \\
\left({ }^{\circ} \mathrm{C}\right)\end{array}$ & $\begin{array}{l}\text { 2nd vo } \\
\text { Pressu } \\
\text { (KPa) }\end{array}$ & & $\begin{array}{l}\text { ANALYSIS } \\
\text { DATE }\end{array}$ & $\begin{array}{l}\text { Probe } \\
\text { Conc. } \\
\text { (m/cc) }\end{array}$ & $\% \mathrm{NH}_{3}$ \\
\hline $\mathrm{NH}_{3}$ & & & & & & & & \\
\hline
\end{tabular}

Hg PUMP INSOLUBLE EXTRACTOR GASES TO COLLECTION CANISTERS.

RGS-002 RGS-003

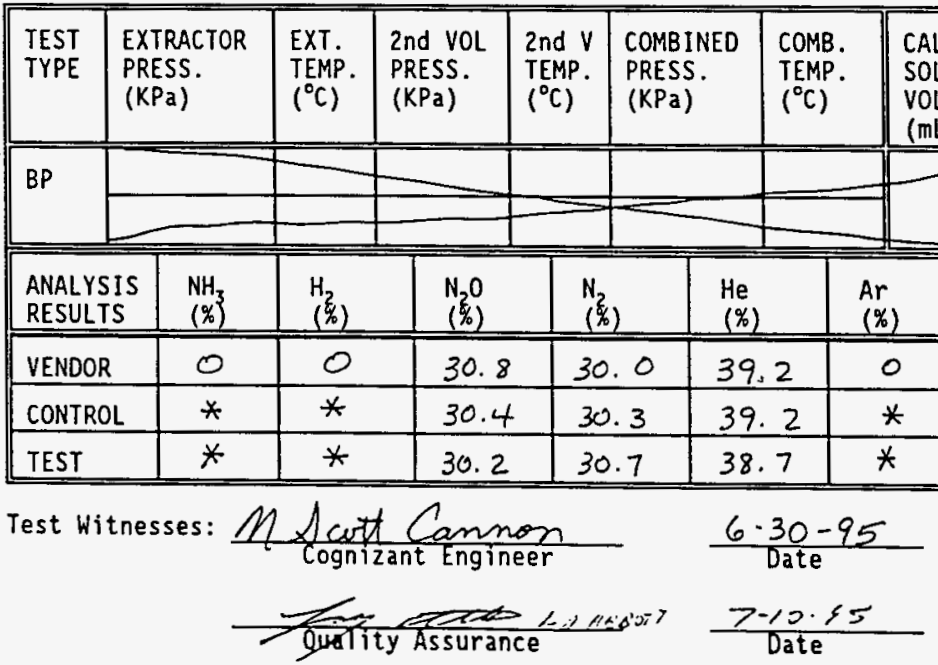

* Less than $0.1 \%$ 
TABLE 12

Summary of Required Injection Test Results

\begin{tabular}{|c|c|c|c|c|c|c|c|c|}
\hline \multicolumn{9}{|c|}{ GAS COMPOSITION ANALYSIS } \\
\hline Test ID & Type & $\begin{array}{l}\mathrm{NH}_{3} \\
(\%)\end{array}$ & $\mathrm{H}_{2}$ & $\begin{array}{l}\mathrm{N}_{2} \mathrm{O} \\
(\%)\end{array}$ & $N_{2}$ & $\begin{array}{l}\mathrm{He} \\
(\%)\end{array}$ & $\begin{array}{l}\mathrm{Ar} \\
(\%)\end{array}$ & $\begin{array}{l}0_{2} \\
(\%)\end{array}$ \\
\hline MIX\#2 & Vendor & -- & -- & 30.8 & 30.0 & 39.2 & -- & -- \\
\hline RGS-002 & Control & -- & -- & 30.4 & 30.3 & 39.2 & - & 0.02 \\
\hline RGS-001 & $26.7^{\circ} \mathrm{C}$ & - & -- & 29.0 & 32.7 & 37.1 & 0.1 & 1.04 \\
\hline RGS-001 & Leak Adj. & -- & -- & 30.5 & 30.3 & 39.0 & 0 & 0 \\
\hline RGS-003 & $52.7^{\circ} \mathrm{C}$ & -- & - & 30.2 & 30.7 & 38.7 & - & 0.27 \\
\hline RGS-003 & Leak Adj. & -- & -- & 30.6 & 30.1 & 39.2 & 0 & 0 \\
\hline MIX\#I & Vendor & 5.0 & 30.3 & -- & 39.8 & - & 24.9 & -- \\
\hline RGS-004 & Control & 2.9 & 29.2 & -- & 41.7 & - & 25.9 & -- \\
\hline $\begin{array}{l}\text { MIX\#1 } \\
\text { Vendor }\end{array}$ & $\begin{array}{l}\mathrm{NH} 3 \text { Loss } \\
\text { Compensated }\end{array}$ & $\underline{2.9}$ & 31.0 & -- & 40.7 & -- & 25.4 & -- \\
\hline RGS-005 & $28.0^{\circ} \mathrm{C}$ & 1.4 & 28.2 & -- & 43.9 & $=$ & 25.6 & 0.78 \\
\hline $\begin{array}{l}\text { MIX\#1 } \\
\text { Control } \\
\end{array}$ & $\begin{array}{l}\text { NH3 Loss } \\
\text { Compensated }\end{array}$ & $\underline{1.4}$ & 29.7 & -- & 42.5 & -- & 26.4 & -- \\
\hline RGS-005 & Leak Adj. & 1.45 & 29.3 & -- & 42.5 & -- & 26.6 & 0 \\
\hline RGS-006 & $52.4^{\circ} \mathrm{C}$ & 1.8 & 29.4 & -- & 42.4 & -- & 26.0 & 0.30 \\
\hline $\begin{array}{l}\text { MIX\#1 } \\
\text { Control } \\
\end{array}$ & $\begin{array}{l}\text { NH3 Loss } \\
\text { Compensated }\end{array}$ & $\underline{1.8}$ & 29.6 & -- & 42.3 & -- & 26.3 & -- \\
\hline RGS-006 & Leak Adj. & 1.83 & 29.8 & -- & 41.9 & -- & 26.4 & 0 \\
\hline
\end{tabular}

\begin{tabular}{||l|l|c|l|l|l|l|l||}
\hline \multicolumn{7}{|c|}{ GAS QUANTITY ANALYSIS - HG PUMP METHOD } \\
\hline \hline Test ID & $\begin{array}{l}\text { Gas } \\
\text { Mix }\end{array}$ & $\begin{array}{l}\text { Starting } \\
\text { Inj. Gas } \\
\text { at STP } \\
\text { (mL) }\end{array}$ & $\begin{array}{l}\text { Final } \\
\text { Canister } \\
\text { Pressure } \\
\text { (KPa) }\end{array}$ & $\begin{array}{l}\text { Final } \\
\text { Canister } \\
\text { Temp. } \\
\left({ }^{\circ} \mathrm{C}\right)\end{array}$ & $\begin{array}{l}\text { Final } \\
\text { Canister } \\
\text { Gas QSTP } \\
\text { (mL) }\end{array}$ & $\begin{array}{l}\text { Adjusted } \\
\text { (2ndV) } \\
\text { Gas GSTP } \\
\text { (mL) }\end{array}$ & $\begin{array}{l}\text { Gas } \\
\text { Transf. } \\
\text { Error } \\
\text { (mL) }\end{array}$ \\
\hline \hline RGS-001 & MIX\#2 & 37.80 & 63.61 & 32.3 & 33.86 & 40.76 & 3.0 \\
\hline RGS-003 & MIX\#2 & 38.69 & 59.09 & 31.9 & 31.49 & 37.91 & -0.8 \\
\hline RGS-005 & MIX\#1 & 36.99 & 59.57 & 32.3 & 31.71 & 38.17 & 1.2 \\
\hline RGS-006 & MIX\#1 & 37.46 & 56.43 & 29.5 & 30.32 & 36.49 & -1.0 \\
\hline
\end{tabular}


TABI_E 13

$\begin{array}{ll}\text { WHC-SD- } \\ \text { INJECTION TEST DATA SHEET } & \text { Rev. } 1 \\ \text { Page } 46\end{array}$

TEST DATE $7-11-95$ Test Performer N.S. SanNoN

GAS MIX ID $M I X+\left(\mathrm{NH}_{3}+\right) \quad$ CANISTER TEMP. $28^{\circ} \mathrm{C}$

CANISTER VOL. (mL) 44.3 CANISTER PRESS. $100.07 \mathrm{KP}$ ( 750.5 Tom)

\begin{tabular}{|c|c|c|c|c|c|c|}
\hline $\begin{array}{l}\text { TEST } \\
\text { TYPE }\end{array}$ & $\begin{array}{l}\text { TEST } \\
\text { STEP }\end{array}$ & $\begin{array}{l}\text { TIME } \\
*\end{array}$ & $\begin{array}{l}\text { TEMP. } \\
\left({ }^{\circ} \mathrm{C}\right)\end{array}$ & $\begin{array}{c}\text { Sensor } 1 \\
{[1000 \mathrm{~T}]} \\
(\mathrm{KPa})\end{array}$ & $\begin{array}{c}\text { Sensor } 2 \\
{[100 \mathrm{~T}]} \\
(\mathrm{KPa})\end{array}$ & $\begin{array}{c}\text { Sensor } 3 \\
{[10 \mathrm{~T}]} \\
(\mathrm{KPa})\end{array}$ \\
\hline \multirow[t]{7}{*}{ SPT } & Zero & $2: 50 \mathrm{Pm}$ & 28.0 & 0.05 & 0.014 & 0.0138 \\
\hline & Leak Test Start & $2: 55$ & 28.0 & 0.05 & 0.014 & 0.0138 \\
\hline & Leak Test End & 3.05 & 28.0 & 0.09 & 0.067 & 0.0662 \\
\hline & Extractor Start & $3: 07: 30$ & 28.1 & 2,62 & 2.637 & OFF S \\
\hline & Extractor End & $3: 18$ & 28.0 & 2.59 & 2.621 & OFF $S$ \\
\hline & 2nd Vol. Start & $3: 19$ & 28.0 & 2.21 & 2.237 & QFFS \\
\hline & 2nd Vol. End & $3: 29$ & 28.0 & 2.24 & 2.267 & $O F F S$ \\
\hline
\end{tabular}

(a)

R65.005

\begin{tabular}{||c|c|c|c|c||l|l|c||}
\hline $\begin{array}{l}\text { TEST } \\
\text { TYPE }\end{array}$ & $\begin{array}{l}\text { Solution } \\
\text { Volume } \\
(\mathrm{mL})\end{array}$ & $\begin{array}{l}\text { Mix } \\
\text { Time }\end{array}$ & $\begin{array}{l}\text { 2nd V } \\
\text { TEMP. } \\
\left({ }^{\circ} \mathrm{C}\right)\end{array}$ & $\begin{array}{l}\text { 2nd VOL. } \\
\text { Pressure } \\
(\mathrm{KPa})\end{array}$ & $\begin{array}{l}\text { ANALYSIS } \\
\text { DATE }\end{array}$ & $\begin{array}{l}\text { Probe } \\
\text { Conc. } \\
(\mathrm{m} / \mathrm{Cc})\end{array}$ & $\% \mathrm{NH}_{3}$ \\
\hline $\mathrm{NH}_{3}$ & 52.3 & $3: 31$ & 28.0 & 2.267 & $7-13.95$ & $1.07 \times 10^{-7}$ & 2.1 \\
\hline
\end{tabular}

Hg PUMP INSOLUBLE EXTRACTOR GASES TO COLLECTION CANISTERS.

* Adjusted for lente rate

\begin{tabular}{||l|l|l|l|l|l|l||l||}
\hline $\begin{array}{l}\text { TEST } \\
\text { TYPE }\end{array}$ & $\begin{array}{l}\text { EXTRACTOR } \\
\text { PRESS. } \\
(\mathrm{KPa})\end{array}$ & $\begin{array}{l}\text { EXT. } \\
\text { TEMP. } \\
\left({ }^{\circ} \mathrm{C}\right)\end{array}$ & $\begin{array}{l}\text { 2nd VOL } \\
\text { PRESS. } \\
(\mathrm{KPa})\end{array}$ & $\begin{array}{l}\text { 2nd V } \\
\text { TEMP. } \\
\left({ }^{\circ} \mathrm{C}\right)\end{array}$ & $\begin{array}{l}\text { COMBINED } \\
\text { PRESS. } \\
(\mathrm{KPa})\end{array}$ & $\begin{array}{l}\text { COMB. } \\
\text { TEMP. } \\
\left({ }^{\circ} \mathrm{C}\right)\end{array}$ & $\begin{array}{l}\text { CALCULATED } \\
\text { SOL ID/LIQUID } \\
\text { VOLUME } \\
(\mathrm{mL})\end{array}$ \\
\hline \hline BP & & & & & & & \\
\hline
\end{tabular}

Test Witnesses: $\frac{21 \text { fentef Commer }}{\text { Cognizant Engineer }} \frac{7-17-95}{\text { Date }}$

RGS.004

RGS_005

* Computer time - alout 19 minates basel.

Data file RGS-005. INT 


\section{TABLE $\because 4$ \\ INJECTION TESST LIATA SHEET Rev. 1}

TEST DATE $7-12-95$ Test Performer N.S. Cannor

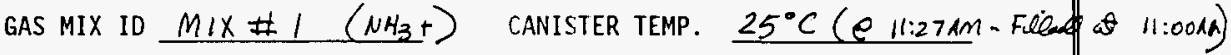
CANISTER VOL. (mL) $4 / .3$ CANISTER PRESS. 752.5 Ton.

\begin{tabular}{|c|c|c|c|c|c|c|}
\hline $\begin{array}{l}\text { TEST } \\
\text { TYPE }\end{array}$ & $\begin{array}{l}\text { TEST } \\
\text { STEP }\end{array}$ & TIME & $\begin{array}{l}\text { TEMP. } \\
\left({ }^{\circ} \mathrm{C}\right) \\
\text { Chen } 2\end{array}$ & $\begin{array}{l}\text { Sensor } 1 \\
{[1000 \mathrm{~T}]} \\
(\mathrm{KPa})\end{array}$ & $\begin{array}{l}\text { Sensor } 2 \\
{[100 \mathrm{~T}]} \\
(\mathrm{KPa})\end{array}$ & $\begin{array}{c}\text { Sensor } 3 \\
{[10 \mathrm{~T}]} \\
(\mathrm{KPa})\end{array}$ \\
\hline \multirow[t]{7}{*}{ SPT } & Zero & $1.11 \mathrm{Pm}$ & 52.4 & 0.03 & .004 & .0043 \\
\hline & Leak Test Start & 1.12 & 52.4 & 0.03 & .004 & .0043 \\
\hline & Leak Test End & $1: 22$ & 52.4 & 0.04 & .019 & 0.0197 \\
\hline & Extractor Start & $1: 23$ & 524 & 0.04 & 0.021 & 0.0210 \\
\hline & Extractor End & $1: 34$ & 52.4 & 2.71 & 2.743 & off sue \\
\hline & 2nd Vol. Start & $1: 35$ & 52.4 & 2.27 & 2.301 & OFFSak \\
\hline & 2nd Vol. End & $1: 46$ & 52.3 & 2.27 & 2.310 & DFF Soule \\
\hline
\end{tabular}

3

RGS.006

\begin{tabular}{|c|c|c|c|c|c|c|c|}
\hline $\begin{array}{l}\text { TEST } \\
\text { TYPE }\end{array}$ & $\begin{array}{l}\text { Solution } \\
\text { Volume } \\
\text { (mL) }\end{array}$ & $\begin{array}{l}\text { Mix } \\
\text { Time } \\
. \\
\end{array}$ & $\begin{array}{l}\text { 2nd V } \\
\text { TEMP. } \\
\left({ }^{\circ} \mathrm{C}\right) \\
\text { Chome } 7\end{array}$ & $\begin{array}{c}\text { 2nd VOL. } \\
\text { Pressure } \\
\text { (KPa) }\end{array}$ & $\begin{array}{l}\text { ANALYSIS } \\
\text { DATE }\end{array}$ & $\begin{array}{l}\text { Probe } \\
\text { Conc. } \\
(\mathrm{m} / \mathrm{cc})\end{array}$ & $\% \mathrm{NH}_{3}$ \\
\hline $\mathrm{NH}_{3}$ & 51.9 & $1: 47$ & 51.1 & .2 .31 & $7-13-95$ & $1.37 \times 10^{-7}$ & $2.7 \%^{x}$ \\
\hline
\end{tabular}

R65.004 R6S- 006

\begin{tabular}{|c|c|c|c|c|c|c|c|c|c|c|}
\hline $\begin{array}{l}\text { TEST } \\
\text { TYPE }\end{array}$ & \multicolumn{2}{|c|}{$\begin{array}{l}\text { EXTRACTOR } \\
\text { PRESS. } \\
\text { (KPa) }\end{array}$} & $\begin{array}{l}\text { EXT. } \\
\text { TEMP. } \\
\left({ }^{\circ} \mathrm{C}\right)\end{array}$ & $\begin{array}{l}\text { 2nd VOL } \\
\text { PRESS. } \\
\text { (KPa) }\end{array}$ & $\begin{array}{l}\text { 2nd } V \\
\text { TEMP. } \\
\left({ }^{\circ} \mathrm{C}\right)\end{array}$ & \multicolumn{2}{|c|}{$\begin{array}{l}\text { COMBINED } \\
\text { PRESS. } \\
(\mathrm{KPa})\end{array}$} & $\begin{array}{l}\text { COMB. } \\
\text { TEMP. } \\
\left({ }^{\circ} \mathrm{C}\right)\end{array}$ & \multicolumn{2}{|c|}{$\begin{array}{l}\text { CALCULATED } \\
\text { SOL ID/LIQUID } \\
\text { VOLUME } \\
(\mathrm{mL}) \\
\end{array}$} \\
\hline \multirow{2}{*}{\multicolumn{11}{|c|}{$B P$}} \\
\hline & & & & & & & & & & \\
\hline \multicolumn{2}{|c|}{$\begin{array}{l}\text { ANALYSIS } \\
\text { RESULTS } \\
\end{array}$} & $\begin{array}{r}\mathrm{NH}_{3} \\
(\%) \\
\end{array}$ & $\begin{array}{l}\mathrm{H}_{2} \\
(\%) \\
\end{array}$ & $\begin{array}{l}\mathrm{N}_{2} \mathrm{O} \\
(\%) \\
\end{array}$ & \multicolumn{2}{|c|}{$\begin{array}{l}\mathrm{N}_{2} \\
(\%) \\
\end{array}$} & \multicolumn{2}{|l|}{$\begin{array}{l}\mathrm{He} \\
(\%) \\
\end{array}$} & $\begin{array}{l}A r \\
(\%)\end{array}$ & $\begin{array}{l}\text { OTHER } \\
(\%) \\
\end{array}$ \\
\hline \multicolumn{2}{|c|}{ VENDOR } & 5.02 & 30.3 & 0 & \multicolumn{2}{|c|}{39.8} & \multicolumn{2}{|l|}{0} & 24.9 & 0 \\
\hline \multicolumn{2}{|c|}{ CONTROL } & 2.9 & 29.2 & 0.0 & \multicolumn{2}{|c|}{41.7} & \multicolumn{2}{|l|}{0} & 25.9 & Methawe 0.2 \\
\hline \multicolumn{2}{|c|}{ TEST } & 81.8 & 29.4 & 0.0 & \multicolumn{2}{|c|}{42.4} & \multicolumn{2}{|c|}{0.0} & 26 & $\begin{array}{l}O_{2}=0.3 \\
\text { me the }=0.1\end{array}$ \\
\hline
\end{tabular}

) Test Witnesses:

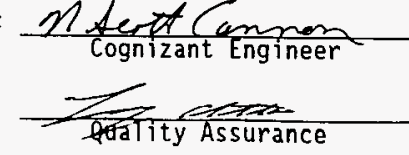

$$
\begin{aligned}
& \frac{7-17-95}{\text { Date }} \\
& 7.77-95^{\circ} \\
& \text { Date }
\end{aligned}
$$

Data fill RGS-006. INJ 
TABLE 15

Ammonia Solution Analysis (ASA) on MIX\#l Control Samples

\begin{tabular}{|c|c|c|c|c|c|c|c|c|c|c|}
\hline \multicolumn{5}{|c|}{$\begin{array}{l}\text { MIX\#1 Sample Acquisition } \\
\text { 6-13-95: D-1 through D-2 } \\
6-14-95: \text { D-3 through D-7 }\end{array}$} & \multicolumn{3}{|c|}{$\begin{array}{l}\text { First Solution } \\
\text { Analysis } 6-15-95 \\
\text { Start Cal }(100)=98.1 \\
\text { End Cal }(100)=117\end{array}$} & \multicolumn{3}{|c|}{$\begin{array}{l}\text { Second Solution } \\
\text { Analys is } 6-16-95 \\
\text { Start Cal }(100)=98.1 \\
\text { End Cal }(100)=117\end{array}$} \\
\hline $\begin{array}{l}\text { Test } \\
\text { Name }\end{array}$ & $\begin{array}{l}\text { Fill } \\
\text { Canister } \\
\text { Vol. (mL) }\end{array}$ & $\begin{array}{l}\text { Fil1 } \\
\text { Pressure } \\
\text { (Torr) }\end{array}$ & $\begin{array}{l}\text { Fill } \\
\text { Temp. } \\
\left({ }^{\circ} \mathrm{C}\right)\end{array}$ & $\begin{array}{l}\text { Solution } \\
\text { Volume } \\
\text { (mL) }\end{array}$ & $\begin{array}{l}\text { Analysis } \\
\text { Order }\end{array}$ & $\begin{array}{l}\text { Raw } \\
\mathrm{NH}_{3} \\
(\%)\end{array}$ & $\begin{array}{l}\text { Adj } \\
\mathrm{NH}_{3} \\
(\%)\end{array}$ & $\begin{array}{l}\text { Analysis } \\
\text { Order }\end{array}$ & $\begin{array}{l}\text { Raw } \\
\mathrm{NH}_{3} \\
(\%)\end{array}$ & $\begin{array}{l}\text { Adj. } \\
\mathrm{NH}_{3} \\
(\%)\end{array}$ \\
\hline D-1 & 42.0 & 12.0 & 22 & 40.36 & 1 & 6.59 & 6.72 & 7 & 9.23 & 7.27 \\
\hline $\mathrm{D}-2$ & 40.9 & 48.3 & 22 & 38.55 & 2 & 5.82 & 5.75 & 6 & 7.54 & 6.13 \\
\hline$D-3$ & 42.0 & 99.4 & 22 & 43.34 & 3 & 4.26 & 4.08 & 5 & 5.16 & 4.34 \\
\hline D-4 & 40.9 & 188.2 & 21 & 41.08 & 4 & 6.39 & 5.94 & 4 & 6.23 & 5.42 \\
\hline D-5 & 42.0 & 250.2 & 21 & 43.29 & 5 & 3.65 & 3.30 & 3 & 3.85 & 3.47 \\
\hline D-6 & 40.9 & 399.7 & 21 & 47.47 & 6 & 5.29 & 4.65 & 2 & 5.29 & 4.94 \\
\hline D-7 & 42.0 & 750.1 & 22 & 43.07 & 7 & 4.96 & 4.24 & 1 & 4.53 & 4.40 \\
\hline \multirow{2}{*}{\multicolumn{5}{|c|}{$\begin{array}{l}\text { Note: Solution Volume was divided } \\
\text { approximately in two, allowing two } \\
\text { separate analyzes to be performed. }\end{array}$}} & AVERAGE = & 5.28 & 4.95 & AVERAGE $=$ & 5.98 & 5.14 \\
\hline & & & & & STD $=$ & 1.00 & 1.12 & $S T D=$ & 1.73 & 1.17 \\
\hline
\end{tabular}

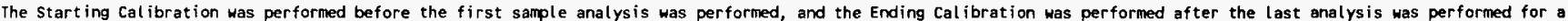
given analysis sequence. Some calibration drift was noted.

AD JUSTED NH 3 \% $=$ RAW NH $3 *(100 /$ [START + (END - START) $6 *$ (ORDER - 13])

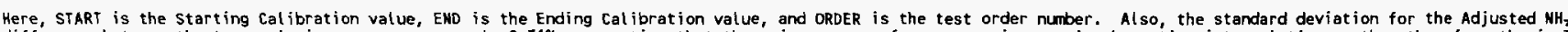

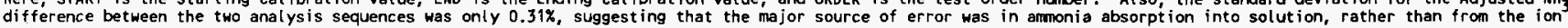
probe. 
TABLE 16

Injection Tests - MIX\#1 Ammonia Analysis

\begin{tabular}{||l|l|l|l|l|l|l|l||}
\hline Test ID & $\begin{array}{l}\text { Test } \\
\text { Date }\end{array}$ & $\begin{array}{l}\text { Fill } \\
\text { Canister } \\
\text { Volume } \\
(\mathrm{mL})\end{array}$ & $\begin{array}{l}\text { Fill } \\
\text { Pressure } \\
(\mathrm{KPa})\end{array}$ & $\begin{array}{l}\text { Fill } \\
\text { Temp. } \\
\left({ }^{\circ} \mathrm{C}\right)\end{array}$ & $\begin{array}{l}\text { Solution } \\
\text { Volume } \\
(\mathrm{mL})\end{array}$ & $\begin{array}{l}\text { Gas } \\
\mathrm{NH}_{3} \\
(\%)\end{array}$ & $\begin{array}{l}\text { QA } \\
\text { Overs. } \\
(\mathrm{Y} / \mathrm{N})\end{array}$ \\
\hline RGS-005 & $7-11-95$ & 320.64 & 2.267 & 28.0 & 52.3 & 2.1 & $\mathrm{Y}$ \\
\hline RGS-006 & $7-12-95$ & 320.64 & 2.31 & 51.1 & 51.9 & 2.7 & $\mathrm{Y}$ \\
\hline A-1 & $7-17-95$ & 320.64 & $\mathrm{NA}$ & Amb. & $\mathrm{NA}$ & 4.6 & $\mathrm{~N}$ \\
\hline A-2 & $7-17-95$ & 320.64 & $\mathrm{NA}$ & $\approx 50$ & $\mathrm{NA}$ & 4.7 & $\mathrm{~N}$ \\
\hline RGS-008 & $7-17-95$ & 320.64 & 2.16 & 25.4 & 40.3 & 3.5 & $\mathrm{Y}$ \\
\hline RGS-009 & $7-18-95$ & 320.64 & 2.368 & 52.2 & 40.4 & 2.7 & $\mathrm{Y}$ \\
\hline RGS-020 & $8-08-95$ & 320.64 & 2.205 & 21.9 & 38.8 & 2.0 & $\mathrm{~N}$ \\
\hline \hline
\end{tabular}


TABLE 17

Wet (Degassed) Mixed Gas Injection Test Composition Results

\begin{tabular}{|c|c|c|c|c|c|c|c|c|}
\hline \multicolumn{9}{|c|}{ GAS COMPOSITION ANALYSIS } \\
\hline Test ID & Comment & $\begin{array}{l}\mathrm{NH}_{3} \\
(\%) \\
\end{array}$ & $\begin{array}{l}\mathrm{H}_{2} \\
(\%)\end{array}$ & $\begin{array}{l}\mathrm{N}_{2} \mathrm{O} \\
(\%) \\
\end{array}$ & $\begin{array}{l}\mathrm{N}_{2} \\
(\%)\end{array}$ & $\begin{array}{l}\mathrm{He} \\
(\%) \\
\end{array}$ & $\begin{array}{l}\mathrm{Ar} \\
(\%) \\
\end{array}$ & $\begin{array}{l}0 \\
(\%) \\
\end{array}$ \\
\hline MIX\#2 & Vendor & -- & -- & 30.8 & 30.0 & 39.2 & -- & -- \\
\hline RGS-002 & Control & -- & -- & 30.4 & 30.3 & 39.2 & -- & 0.02 \\
\hline RGS-025 & $37.6 \mathrm{~mL}$ OSTP & -- & -- & 29.6 & 31.4 & 38.3 & -- & 0.43 \\
\hline RGS-026 & $37.7 \mathrm{~mL}$ ESTP & -- & -- & 30.0 & 30.6 & 39.1 & -- & 0.13 \\
\hline RGS-027 & $20.1 \mathrm{~mL}$ ESTP & -- & -- & 29.9 & 30.5 & 39.3 & -- & 0.14 \\
\hline RGS-028 & $10.1 \mathrm{~mL}$ ESTP & -- & -- & 29.0 & 31.7 & 38.1 & - & 0.95 \\
\hline RGS-029 & 2.5mL QSTP & -- & - & 15.7 & 46.3 & 26.0 & 0.6 & 11.0 \\
\hline MIX\#1 & Vendor & 5.0 & 30.3 & -- & 39.8 & -- & 24.9 & -- \\
\hline RGS-004 & Control & 2.9 & 29.2 & -- & 41.7 & - & 25.9 & -- \\
\hline $\begin{array}{l}\text { MIX\#1 } \\
\text { Control }\end{array}$ & $\begin{array}{l}\text { NH3 Loss } \\
\text { Compensated }\end{array}$ & $\underline{0}$ & 30.2 & -- & 43.1 & -- & 26.8 & -- \\
\hline RGS-037 & $37.2 \mathrm{~mL}$ OSTP & 0 & 29.6 & -- & 43.6 & -- & 26.4 & 0.39 \\
\hline
\end{tabular}

TABLE 18

Wet (Degassed) Mixed Gas Injection Test Quantity Results

\begin{tabular}{|c|c|c|c|c||}
\hline \multicolumn{5}{|c|}{ GAS QUANTITY - AT STP } \\
\hline \hline Test ID & $\begin{array}{l}\text { Start } \\
\text { Quantity } \\
(\mathrm{mL})\end{array}$ & $\begin{array}{l}\text { Hg Pump } \\
\text { Transfer } \\
(\mathrm{mL})\end{array}$ & $\begin{array}{l}\text { Hg Pump } \\
\text { Error } \\
(\%)\end{array}$ & $\begin{array}{l}\text { Hg Pump } \\
\text { Error } \\
\text { (mL) }\end{array}$ \\
\hline RGS-025 & 37.62 & 33.67 & -10.51 & -3.95 \\
\hline RGS-026 & 37.70 & 33.80 & -10.33 & -3.90 \\
\hline RGS-027 & 20.12 & 18.85 & -6.32 & -1.27 \\
\hline RGS-028 & 10.06 & 7.96 & -20.91 & -2.10 \\
\hline RGS-029 & 2.52 & 0.68 & -73.01 & -1.84 \\
\hline RGS-037 & $35.36^{*}$ & 30.81 & -12.86 & -4.55 \\
\hline
\end{tabular}

* Assumes total washout of ammonia, as expected and demonstrated in Table 17. 
TABLE 19

Wet (Degassed) Argon Gas Injection Test Composition Results

\begin{tabular}{|c|c|c|c|c|c|}
\hline Test ID & $\begin{array}{l}\text { COMMENTS } \\
\text { (Volumes given in } \mathrm{mL} \text { are at STP) }\end{array}$ & $\begin{array}{l}\text { Ar } \\
(\%) \\
\end{array}$ & $\begin{array}{l}0_{2} \\
(\%) \\
\end{array}$ & $\begin{array}{l}N_{2} \\
(\%) \\
\end{array}$ & $\begin{array}{c}\text { Error } \\
(\%) \\
\end{array}$ \\
\hline RGS-032 & Control & 99.95 & 0 & 0.02 & NA \\
\hline RGS-044 & Control & 99.95 & 0.01 & 0.03 & NA \\
\hline RGS-033 & BH\#2 Pumped; Start $37.11 \mathrm{~mL}$ & 98.37 & 0.35 & 1.17 & 1.6 \\
\hline RGS-034 & BH\#3 Dumped; Same as RGS-035 & 98.28 & 0.22 & 0.6 & 1.7 \\
\hline RGS-035 & BH\#3 Pumped; Start $20.11 \mathrm{~mL}$ & 99.68 & 0.08 & 0.21 & 0.3 \\
\hline RGS-036 & BH\#4 Pumped; Start $20.09 \mathrm{~mL}$ & 99.6 & 0.08 & 0.26 & 0.4 \\
\hline RGS-038 & Pumped; Start $2.55 \mathrm{~mL}$ & 82.8 & 2.7 & 13.5 & 17.2 \\
\hline RGS-039 & Pumped; Start $5.11 \mathrm{~mL}$ & 96.32 & 0.76 & 2.71 & 3.6 \\
\hline $\begin{array}{c}\text { RGS-043 } \\
\mathrm{B} \\
\end{array}$ & BH\#5 Pumped; Start $5.04 \mathrm{~mL}$ & 94.4 & 1.73 & 3.44 & 5.6 \\
\hline $\begin{array}{c}\text { RGS-043 } \\
C\end{array}$ & BH\#5 Dumped & 94.5 & 1.49 & 2.48 & 5.5 \\
\hline $\begin{array}{c}\text { RGS-045 } \\
\mathrm{A} \\
\end{array}$ & BH\#6 Dumped & 85.9 & 2.73 & 2.22 & 14.1 \\
\hline $\begin{array}{c}R G S-045 \\
B \\
\end{array}$ & BH\#6 Pumped; Start $5.04 \mathrm{~mL}$ & 97 & 0.98 & 1.78 & 2.6 \\
\hline $\begin{array}{c}\text { RGS-046 } \\
A \\
\end{array}$ & BH\#7 Dumped & 31.2 & 17.2 & 18.9 & 68.8 \\
\hline $\begin{array}{c}\text { RGS-046 } \\
B \\
\end{array}$ & BH\#7 Pumped; Start $3.77 \mathrm{~mL}$ & 95.65 & 1.4 & 2.48 & 4.3 \\
\hline RGS-047 & $50.6{ }^{\circ} \mathrm{C}$; Pumped; Start $20.14 \mathrm{~mL}$ & 99.25 & 0.09 & 0.29 & 0.7 \\
\hline $\begin{array}{c}\text { RGS-048 } \\
\mathrm{A} \\
\end{array}$ & Dumped & 92.5 & 1.55 & 5.33 & 7.5 \\
\hline $\begin{array}{c}\text { RGS-048 } \\
\mathrm{B} \\
\end{array}$ & Pumped; Start $10.06 \mathrm{~mL}$ & 93.7 & 1.37 & 4.84 & 6.3 \\
\hline RGS-049 & $50.1{ }^{\circ} \mathrm{C}$; Pumped; Start $10.14 \mathrm{~mL}$ & 98.58 & 0.15 & 0.85 & 1.4 \\
\hline RGS-050 & $50.1{ }^{\circ} \mathrm{C}$; Pumped; Start $5.04 \mathrm{~mL}$ & 97.38 & 0.32 & 1.34 & 2.6 \\
\hline
\end{tabular}


TABLE 20

Wet (Degassed) Argon Injection Test Gas Quantity (QSTP) Results

\begin{tabular}{|c|c|c|c|c|c|c|}
\hline Test ID & Comment & $\begin{array}{l}\text { Expected } \\
V_{g} \\
(m L) \\
\end{array}$ & $\begin{array}{l}\text { RESULT: } \\
\text { Hg Pump } \\
\text { with } P_{v} \\
(\mathrm{~mL})\end{array}$ & $\begin{array}{l}\text { Error } \\
(\mathrm{mL})\end{array}$ & $\begin{array}{l}\text { RESULT: } \\
\text { Hg Pump } \\
P_{V}=0 \\
(m L)\end{array}$ & $\begin{array}{l}\text { Error } \\
(\mathrm{mL})\end{array}$ \\
\hline RGS-033 & Single & 37.11 & 34.79 & -2.32 & 37.02 & -0.25 \\
\hline RGS-035 & Dual: RGS-034 & 20.11 & 16.70 & -3.41 & 18.94 & -1.17 \\
\hline RGS-036 & Single & 20.09 & 14.88 & -5.21 & 17.11 & -2.98 \\
\hline RGS-038 & Single & 2.55 & 1.51 & -1.04 & 3.51 & 0.96 \\
\hline RGS-039 & Single & 5.11 & 2.73 & -2.39 & 4.60 & -0.52 \\
\hline RGS-043C & Dual with B & 5.04 & 2.43 & -2.61 & 4.35 & -0.69 \\
\hline RGS-045B & Dual with $A$ & 5.04 & 2.05 & -2.99 & 3.98 & -1.07 \\
\hline RGS-046B & Dual with A & 3.77 & 1.85 & -1.92 & 3.74 & -0.03 \\
\hline RGS-047 & $\begin{array}{l}\text { Single } \\
50.6{ }^{\circ} \mathrm{C} \\
\end{array}$ & 20.14 & 7.64 & -12.51 & 9.55 & -10.60 \\
\hline RGS-048B & Dual with $A$ & 10.06 & 6.50 & -3.56 & 8.42 & -1.64 \\
\hline RGS-049 & $\begin{array}{l}\text { Single } \\
50.1{ }^{\circ} \mathrm{C}\end{array}$ & 10.14 & 6.10 & -4.04 & 8.02 & -2.13 \\
\hline RGS-050 & $\begin{array}{l}\text { Single o } \\
50.1{ }^{\circ} \mathrm{C} \\
\end{array}$ & 5.04 & 2.27 & -2.77 & 4.22 & -0.82 \\
\hline \multirow{2}{*}{\multicolumn{3}{|c|}{$\begin{array}{l}\text { Excluding RGS-047 (extra } \\
\text { ammonia absorption): }\end{array}$}} & \multirow{2}{*}{$\begin{array}{r}\text { Average }= \\
\text { STD }=\end{array}$} & -2.93 & & -1.11 \\
\hline & & & & 1.10 & & 0.81 \\
\hline
\end{tabular}


TABLE 21

Simulant Extrusion Test Gas Quantity Results

\begin{tabular}{|c|c|c|c|c|c|c|c|c|c|c|c|}
\hline \multicolumn{12}{|c|}{ GAS QUANTITY BT/TV ANALYSIS - QSTP } \\
\hline Test ID & $\begin{array}{l}\text { Max. } \\
\text { Temp. } \\
\left({ }^{\circ} \mathrm{C}\right) \\
\end{array}$ & $\begin{array}{l}\text { Gas } \\
\text { Type }\end{array}$ & $\begin{array}{c}\text { Expected } \\
\mathbf{V}_{\mathrm{sL}} \\
(\mathrm{mL}) \\
\end{array}$ & $\begin{array}{c}\text { BT } \\
\text { Meas. } \\
V_{\text {Sh }} \\
(\mathrm{mL}) \\
\end{array}$ & $\begin{array}{c}\underset{V_{g}}{\text { Expected }} \\
(\mathrm{mL}) \\
\end{array}$ & $\begin{array}{l}\text { TV } \\
\text { Meas. } \\
V_{0} \\
(\mathrm{~mL}) \\
\end{array}$ & $\begin{array}{l}V_{g} \\
\text { Error } \\
(\mathrm{mL}) \\
\end{array}$ & $\begin{array}{c}\begin{array}{l}V_{g} \\
\text { Error }\end{array} \\
(\%) \\
\end{array}$ & $\begin{array}{c}\text { Expect. } \\
P_{v} \\
(\mathrm{KPa}) \\
\end{array}$ & $\begin{array}{c}\text { TV } \\
\text { Meas. } \\
P_{Y} \\
(\mathrm{KPa}) \\
\end{array}$ & $\begin{array}{c}\text { Error } \\
(\%) \\
\end{array}$ \\
\hline RGS-051 & 21.0 & Argon & 287.0 & 288.36 & 25.7 & 26.8 & 1.1 & 4.3 & 2.487 & 2.53 & 1.7 \\
\hline RGS-052 & 50.5 & Argon & 284.2 & 280.63 & 28.1 & 35.8 & 7.7 & 27.2 & 2.502 & 2.49 & -0.4 \\
\hline RGS-053 & 51.3 & Helium & 287.5 & 284.06 & 25.3 & 28.7 & 3.4 & 13.4 & 2.487 & 2.53 & 1.9 \\
\hline
\end{tabular}

\begin{tabular}{|c|c|c|c|c|c|c|c|c|c|c|c|}
\hline \multicolumn{12}{|c|}{ GAS QUANTITY Hg PUMP ANALYSIS - ESTP } \\
\hline Test ID & $\begin{array}{l}\text { Max. } \\
\text { Temp. } \\
\left({ }^{\circ} \mathrm{C}\right)\end{array}$ & $\begin{array}{l}\text { Gas } \\
\text { Type }\end{array}$ & $\begin{array}{l}\text { BT } \\
\text { Meas. } \\
\mathbf{v}_{\text {sL }} \\
(\mathrm{mL})\end{array}$ & $\begin{array}{l}\text { Expected } \\
V_{g} \\
(\mathrm{~mL})\end{array}$ & $\begin{array}{l}\text { RESULT: } \\
\text { Hg Pump } \\
\text { with } P_{v} \\
\text { (mL) }\end{array}$ & $\begin{array}{l}\text { Error } \\
(\mathrm{mL})\end{array}$ & $\begin{array}{l}\text { RESULT: } \\
\text { Hg Pump } \\
P_{V}=0 \\
(\mathrm{~mL})\end{array}$ & $\begin{array}{l}\text { Error } \\
(\mathrm{mL})\end{array}$ & $\begin{array}{l}\underset{P_{v}}{\operatorname{Exp}} \\
(\mathrm{KPa})\end{array}$ & $\begin{array}{l}\underset{P_{V}}{\mathrm{Hg}} \mathrm{P} . \\
(\mathrm{KPa})\end{array}$ & $\begin{array}{c}\text { Error } \\
(\%)\end{array}$ \\
\hline RGS-051 & 21.0 & Argon & 288.36 & 25.7 & 21.0 & -4.7 & 23.0 & -2.7 & 2.487 & 3.00 & 20.6 \\
\hline RGS-052 & 50.5 & Argon & 280.63 & 28.1 & 25.5 & -2.6 & 27.6 & -0.5 & 2.502 & 3.13 & 25.1 \\
\hline RGS-053 & 51.3 & Hel ium & 284.06 & 25.3 & 20.8 & -4.5 & 23.0 & -2.3 & 2.487 & 3.21 & 29.1 \\
\hline
\end{tabular}


TABLE 22

Simulant Extrusion Test Gas Composition Results

\begin{tabular}{||l|c|c|c|c|c|c||}
\hline \hline \multicolumn{7}{|c|}{ GAS COMPOSITION ANALYSIS } \\
\hline \hline Test ID & $\begin{array}{c}\text { Maximum } \\
\text { Temperature } \\
\left({ }^{\circ} \mathrm{C}\right)\end{array}$ & $\begin{array}{c}\text { Expected } \\
\text { Gas } \\
\text { Type }\end{array}$ & $\begin{array}{c}\text { Argon } \\
(\%)\end{array}$ & $\begin{array}{c}\text { Hel ium } \\
(\%)\end{array}$ & $\begin{array}{c}\text { 0xygen } \\
(\%)\end{array}$ & $\begin{array}{c}\text { Nitrogen } \\
(\%)\end{array}$ \\
\hline \hline $\begin{array}{l}\text { RGS-032 } \\
\text { Control }\end{array}$ & NA & Argon & 99.95 & 0.02 & 0 & 0.02 \\
\hline $\begin{array}{l}\text { RGS-044 } \\
\text { Control }\end{array}$ & NA & Argon & 99.95 & 0 & 0.01 & 0.03 \\
\hline RGS-051 & 21.0 & Argon & 97.98 & 0 & 0.18 & 1.8 \\
\hline RGS-052 & 50.5 & Argon & 91.3 & 0 & 1.6 & 7.0 \\
\hline \hline $\begin{array}{l}\text { RGS-054 } \\
\text { Control }\end{array}$ & NA & Helium & 0 & 99.78 & 0.02 & 0.19 \\
\hline RGS-053 & 51.3 & Helium & 0.07 & 96.89 & 0.47 & 2.46 \\
\hline \hline
\end{tabular}


TABLE 23

Sampler Aging Test Gas Composition Results

\begin{tabular}{|c|c|c|c|c|c|c|c|c|}
\hline $\begin{array}{l}\text { Test } \\
\text { ID }\end{array}$ & Description/Comment & $\begin{array}{r}\mathrm{NH}_{3} \\
(\%) \\
\end{array}$ & $\begin{array}{r}\mathrm{H}_{2} \\
(\%) \\
\end{array}$ & $\begin{array}{l}\mathrm{N}_{2} \mathrm{O} \\
(\%) \\
\end{array}$ & $\begin{array}{l}N_{2} \\
(\%) \\
\end{array}$ & $\begin{array}{l}\text { He } \\
(\%) \\
\end{array}$ & $\begin{array}{l}\mathrm{Ar} \\
(\%) \\
\end{array}$ & $\begin{array}{r}0 \\
(\%) \\
\end{array}$ \\
\hline MIX\#1 & Vendor Certification (see Table 8) & 5.0 & 30.3 & -- & 39.8 & -- & 24.9 & -- \\
\hline RGS-004 & $\begin{array}{r}\text { Control: PNNL IMS Lab Analysis } \\
(7-12-95 \text { Log-in No. 95-07111) }\end{array}$ & 2.9 & 29.2 & -- & 41.7 & -- & 25.9 & 0.007 \\
\hline RGS-055 & $\begin{array}{l}\text { Aged } 24 \text { hrs }(1 d) \text { IMS Lab Analys is } \\
(9-13-95 \text { Log-in No. } 95-08647)\end{array}$ & 1.3 & 31.0 & -- & 41.6 & -- & 26.1 & 0.022 \\
\hline СOMP 1 & $\begin{array}{l}\text { Expected Composition based on RGS-004 (Control) } \\
\text { Compensation Calculated for NH3 Loss. }\end{array}$ & $\underline{1.3}$ & 29.8 & -- & 42.5 & -- & 26.4 & 0.01 \\
\hline RGS-056 & $\begin{array}{l}\text { Aged } 74 \mathrm{hrs}(3.1 \text { d) IMS Lab Analys is } \\
(9-15-95 \text { Log-in No. } 95-08719) \quad \text { [See COMP 1] }\end{array}$ & 1.3 & 30.5 & -- & 41.9 & -- & 26.2 & 0.022 \\
\hline $\mathrm{RGS}-057$ & $\begin{array}{l}\text { Aged } 187 \mathrm{hr}(7.8 \mathrm{~d}) \text { IMS Lab Analys is } \\
(9-21-95 \mathrm{Log}-\text { in No. } 95-08778)\end{array}$ & 0.04 & 31.3 & -- & 42.2 & -- & 26.4 & 0.010 \\
\hline COMP 2 & $\begin{array}{l}\text { Expected Composition based on RGS-004 (Control) } \\
\text { Compensation Calculated for NH3 Loss. }\end{array}$ & $\underline{0.04}$ & 30.2 & -- & 43.1 & -- & 26.7 & 0.01 \\
\hline RGS-058 & $\begin{array}{l}\text { Aged } 1829 \mathrm{hrs}(76 \mathrm{~d}) \text { IMS Lab Analysis } \\
(11-30-95 \mathrm{Log}-\text { in No. } 96-01643) \\
\text { Sampler gas pressure was } 0.33 \mathrm{~atm} \text {. }\end{array}$ & 0.23 & 30.5 & -- & 42.7 & -- & 26.5 & 0.054 \\
\hline COMP 3 & $\begin{array}{l}\text { Expected Composition based on RGS-004 (Control) } \\
\text { Compensation Calculated for NH3 Loss. }\end{array}$ & $\underline{0.23}$ & 30.1 & -- & 43.0 & -- & 26.7 & 0.01 \\
\hline
\end{tabular}

Ammonia loss during PNNL's Mass Spectrometer analysis will alter the relative composition of other gas components. Calculations were performed (as described in Appendix D) to compensate for the decreased ammonia concentrations actually measured; these calculations (based on RGS-004 control data) produced "Expected" Compositions (COMP 1, 2, and 3) for comparison with test results. The RGS-004 control data was used for the Expected Composition calculations because this allows these comparisons to all be made with gas composition analysis performed by the same high accuracy mass spectrometer. 


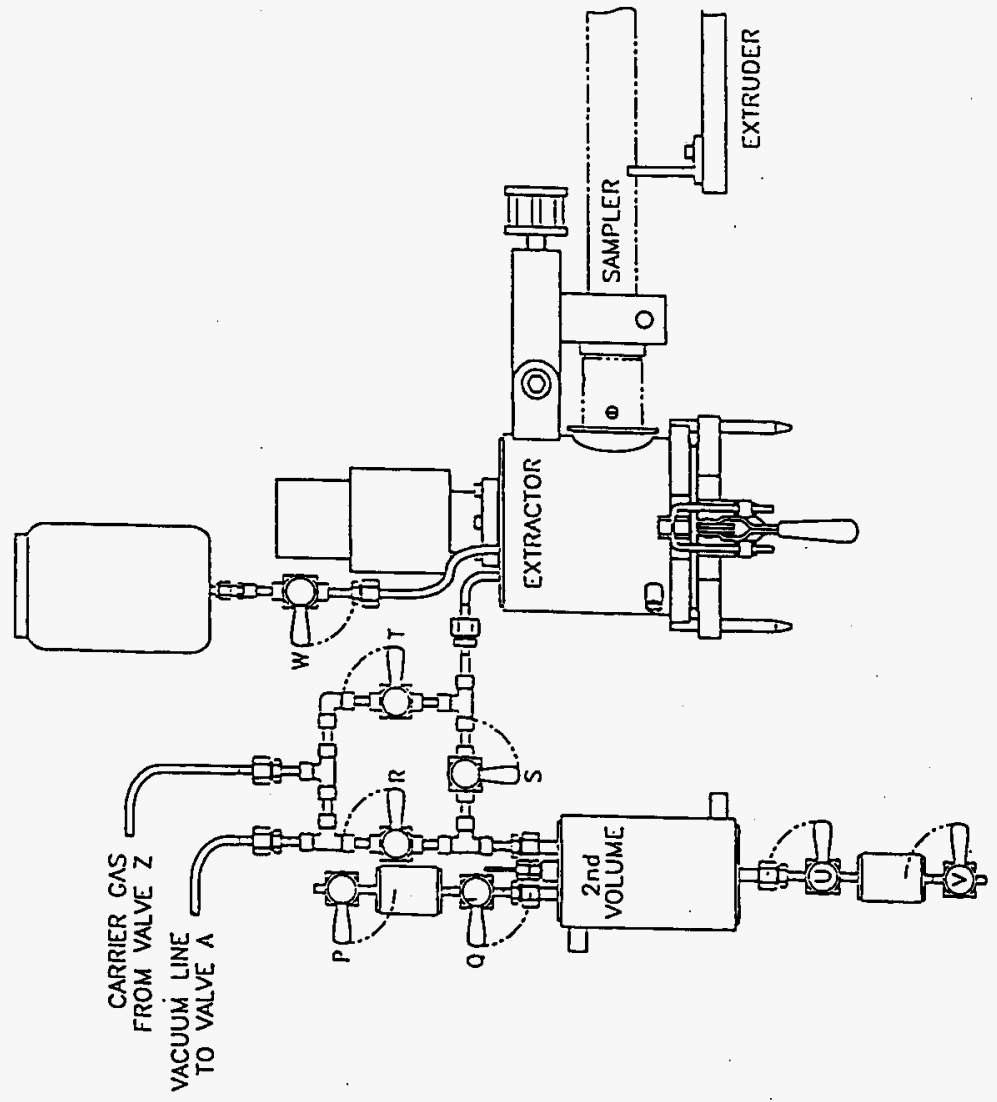

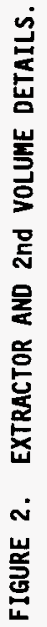




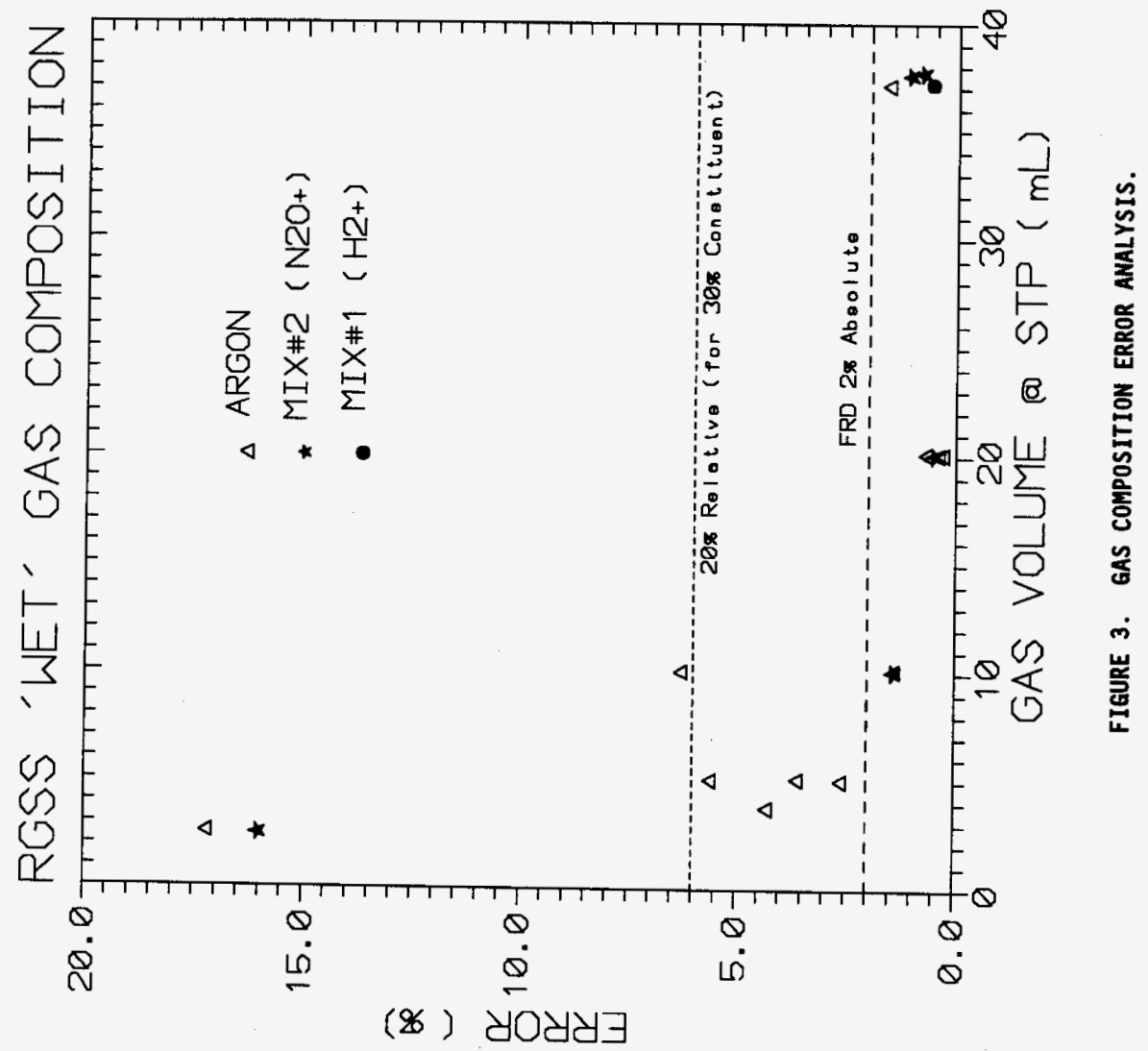




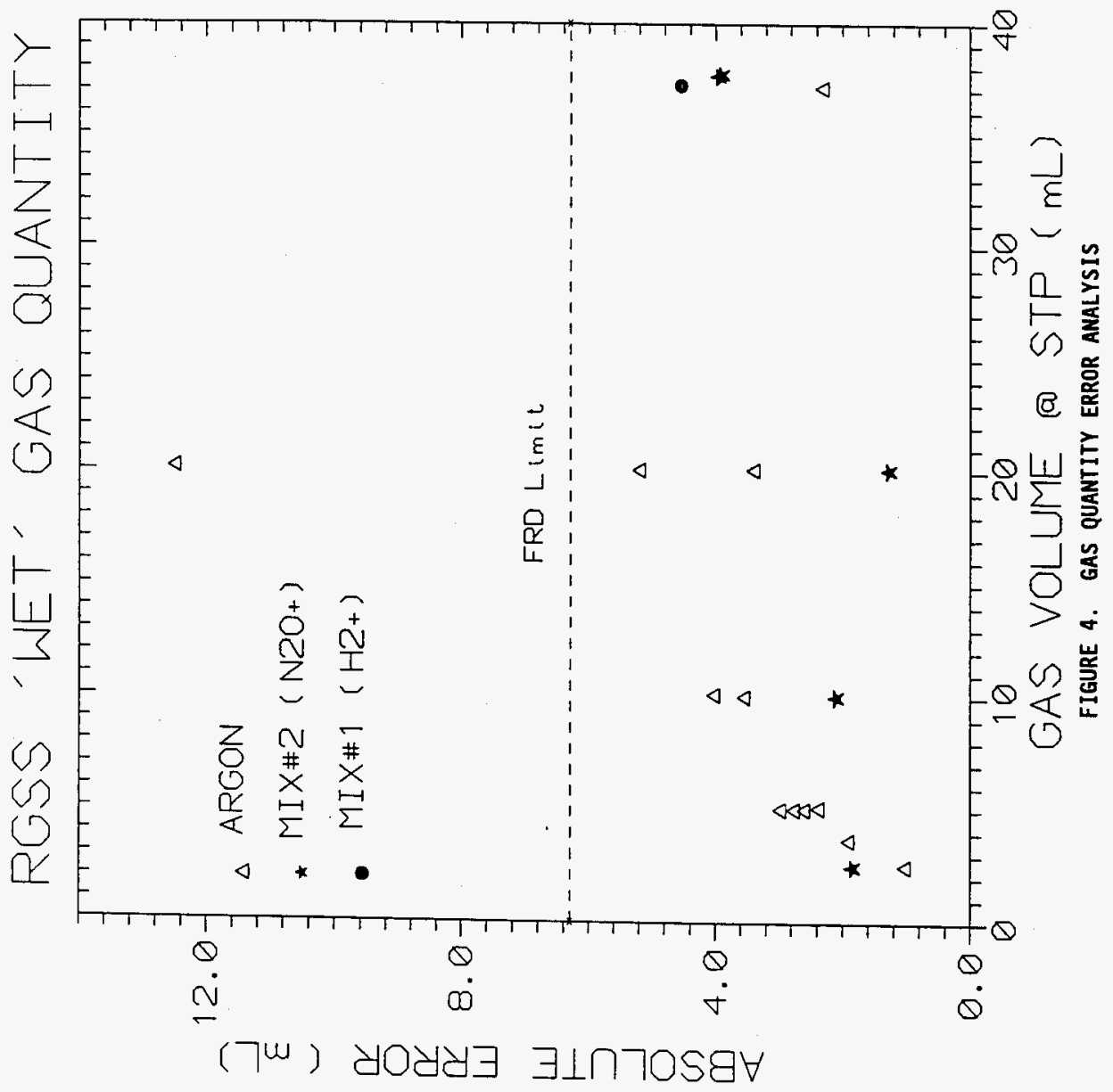




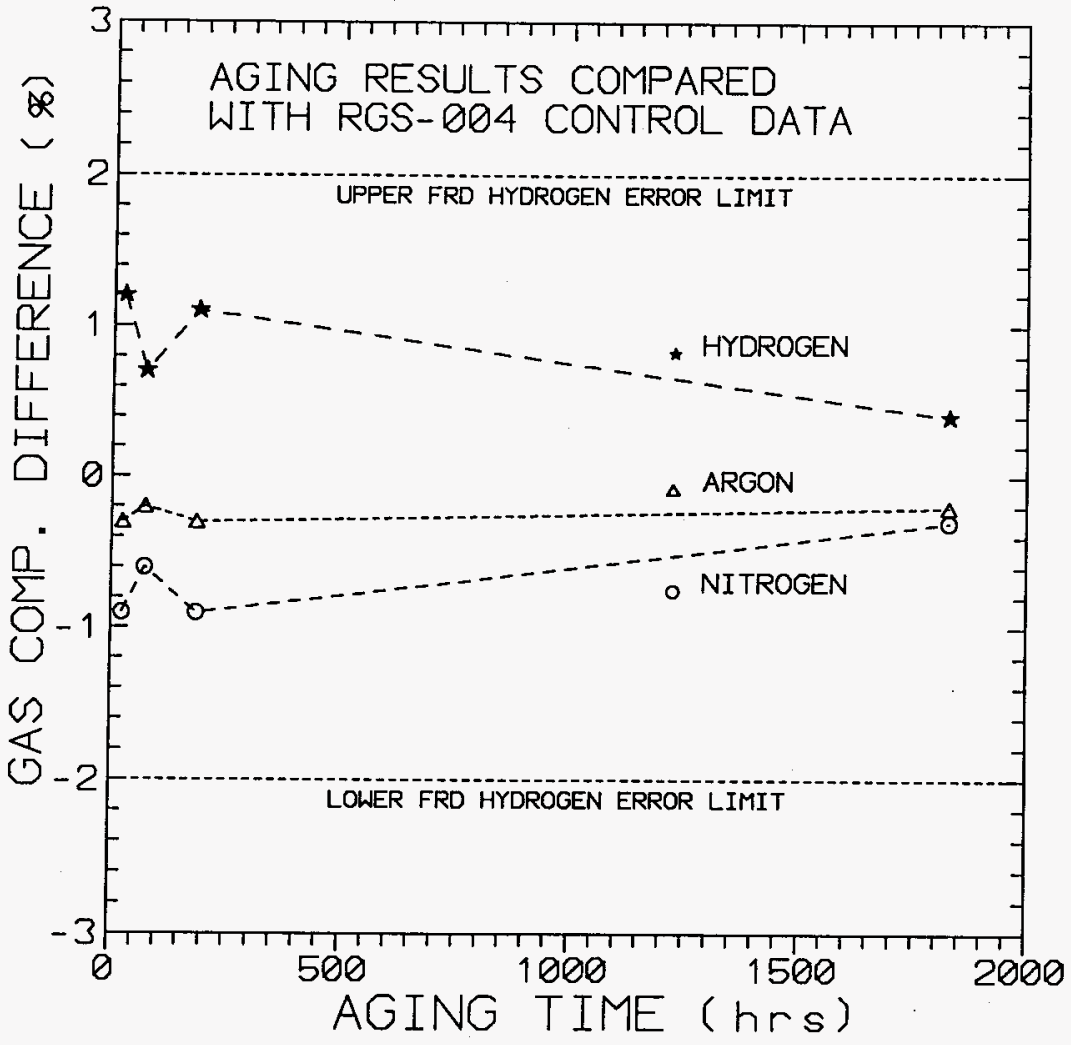

FIGURE 5. GAS COMPOSITION DIFFERENCE (MEASURED - EXPECTED) IS PLOTTED VERSUS SAMPLER AGING TIME FOR HYDROGEN, ARGON AND NITROGEN. 


\section{APPENDIX A}

\section{RGSS Instrumentation Calibration}

All of the RGSS instrumentation requiring calibration for Acceptance Testing are listed below; this list includes the location of calibration data for each instrument or transducer.

\begin{tabular}{||l|c|c|c||}
\hline \hline INSTRUMENT & $\begin{array}{l}\text { WHC STANDARDS } \\
\text { LAB \# }\end{array}$ & $\begin{array}{l}\text { CALIBRATION } \\
\text { TABLE \# }\end{array}$ & $\begin{array}{l}\text { CALIBRATION } \\
\text { DATES }\end{array}$ \\
\hline \hline $\begin{array}{l}\text { MKS Baratron 622 Pressure } \\
\text { Transducer (10 Torr) }\end{array}$ & $559-80-02-012$ & $\begin{array}{l}\text { A-1 } \\
\text { A-2 }\end{array}$ & $\begin{array}{l}9-01-94 \text { to 9-01-95 } \\
9-15-95 \text { to 9-15-96 }\end{array}$ \\
\hline $\begin{array}{l}\text { MKS Baratron 622 Pressure } \\
\text { Transducer (100 Torr) }\end{array}$ & $559-80-02-013$ & $\begin{array}{l}\text { A-3 } \\
\text { A-4 }\end{array}$ & $\begin{array}{l}9-01-94 \text { to 9-01-95 } \\
9-15-95 \text { to 9-15-96 }\end{array}$ \\
\hline $\begin{array}{l}\text { MKS Baratron 622 Pressure } \\
\text { Transducer (1000 Torr) }\end{array}$ & $559-80-02-011$ & $\begin{array}{l}\text { A-5 } \\
\text { A-6 }\end{array}$ & $\begin{array}{l}9-01-94 \text { to 9-01-95 } \\
9-14-95 \text { to 9-14-96 }\end{array}$ \\
\hline $\begin{array}{l}\text { HP3497A DACU } \\
\text { Type K Thermocoupies, PO WFJ-XVV- } \\
\text { 257890 from ARI. }\end{array}$ & NA & A-8 & N-30-95 to 5-30-96 \\
\hline
\end{tabular}

The MKS pressure transducers were recalibrated at the end of the acceptance testing; as noted in Tables $A-4$ and $A-6$, the 100 and 1000 Torr transducers, respectively, were found to be out of specification. Table A-9 contains a summary of the calibration error measured for these two transducers. Pressure data errors affect only the BT, TV and $\mathrm{Hg}$ Pump method gas quantity/void fraction results. The consequences of these potential errors on the acceptance test results will be evaluated in the following.

For the BT method, during acceptance testing, only the 1000 Torr transducer was used. The BT analysis uses only a difference in pressure measurements to determine sample solid/liquid volume (see Equation 2); thus, the transducer error is nearly eliminated in the $V_{s L}$ calculation since the pressure error is relatively constant (between 1.7 and 2.6 Torr) over the transducer's range (see Table A-9). For example, in the case of RGS-053, the pressure transducer error for the measured pressures would be expected to produce a high value for $V_{\text {st }}$ by about 0.2 percent.

The Two Volume method calculates gas quantity based on the difference between pressure measurements (see Equation 5), also. However, the 100 Torr MKS transducer used for the TV measurements has more variability in the error over the range of the transducer than for the 1000 Torr transducer. The actual pressure measurements for the three tests of interest (RGS-051, RGS-052 and RGS-053) were between 4 and $5.3 \mathrm{KPa}$ ( 30 to $40 \mathrm{Torr}$ ). Based on the 
recalibration data given in. Table A-9, the worst case pressure difference error might conservatively be as large as $0.18 \mathrm{Torr}$, or $0.024 \mathrm{KPa}$. This would correspond to overpredictions of gas quantity of 5.3 percent (RGS-051), 4.0 percent (RGS-052), and 4.9 percent (RGS-053). Compensation for these pressure measurement errors would actually improve the results presented in Table 21 .

The Hg Pump method for determining total gas quantity again uses a difference in pressure readings (see Equation 4). The $P_{f}$ pressure measurements were based entirely on the 1000 Torr transducer; however, the $P_{v}$ pressure measurements were most often obtained using the 100 Torr transducer, and always ranged between 20 and 30 Torr. In cases where both pressure measurements were based on the 1000 Torr transducer, the gas quantity would have been overestimated (due to pressure measurement error) by no more than 0.3 percent, a small effect. In the cases where $P_{v}$ was determined with the 100 Torr transducer, the error in the pressure difference $P_{f}-P_{v}$ might have been as large as 2.4 Torr.

The effect of this potential pressure measurement error on gas quantity determination is summarized in Table A-10 for all reported $\mathrm{Hg}$ Pump results, assuming that a worst case pressure difference error of 2.6 Torr ( $0.35 \mathrm{KPA})$ occurred. The "corrected" error in gas quantity measurement given in Table A-10 in units of volume (mL) is essentially the same as that given in Tables 12, 18, 20, and 21; all errors (except for test RGS-047) remain within the range allowed by the FRD of $6.3 \mathrm{~mL}$ for a full sampler. (The RGS-047 result continues to be out of specification, presumably because the abnormally low extractor temperature of $15.6{ }^{\circ} \mathrm{C}$ during gas transfer allowed more gas to remain dissolved in solution, as previously discussed.)

Thus, acceptance test results for gas quantity and void fraction were only slightly altered by assuming worst case pressure measurement errors resulting from the calibration drift in the two MKS pressure transducers. The error analysis made using worst case pressure data assumptions demonstrated that the RGSS continued to meet the FRD requirements under these conditions. 
WESTINGHOUSE STANDAROS LABORATORY PHYSICAL AND ELECTRICAL REPORT

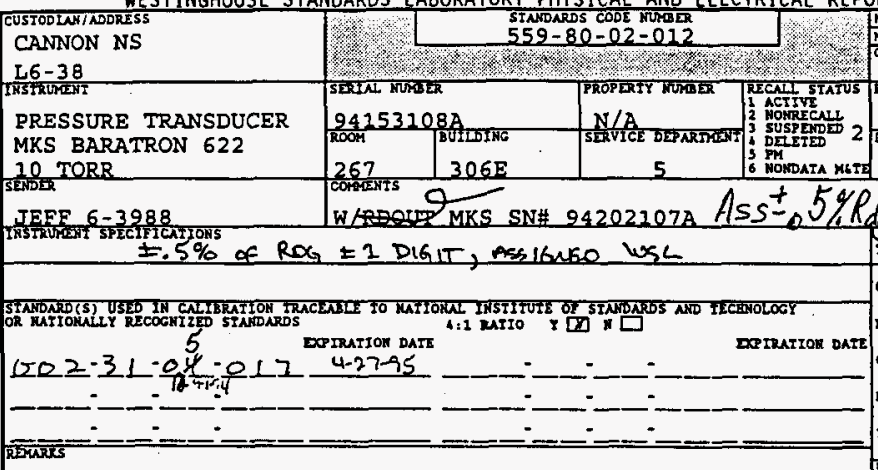

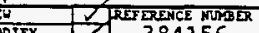

ORGANIZATIOH CODE 384156

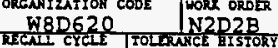
NStktiti

PRESSURE TRANSDUCER

MKS BARATRON 622 STRET

988

$\pm .5 \%$ of $R X_{2} \pm 1$ DIGIT, Assl6uko w5L

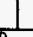

OLFURCE HISTOKY

$\frac{360}{\text { DIE REIVED }}$

TótERTCE

$\frac{940879}{ \pm 1 D^{2}}$

3.

Trumine bours

cactroutron boors 20

TIPAIR BOORS

OTEER BOUTS

Mrexints

TOTAL CBNREE -

(S 120 × SUM of BOURS) + MATRRTW DAFE CALIBRATE TEATE DUE

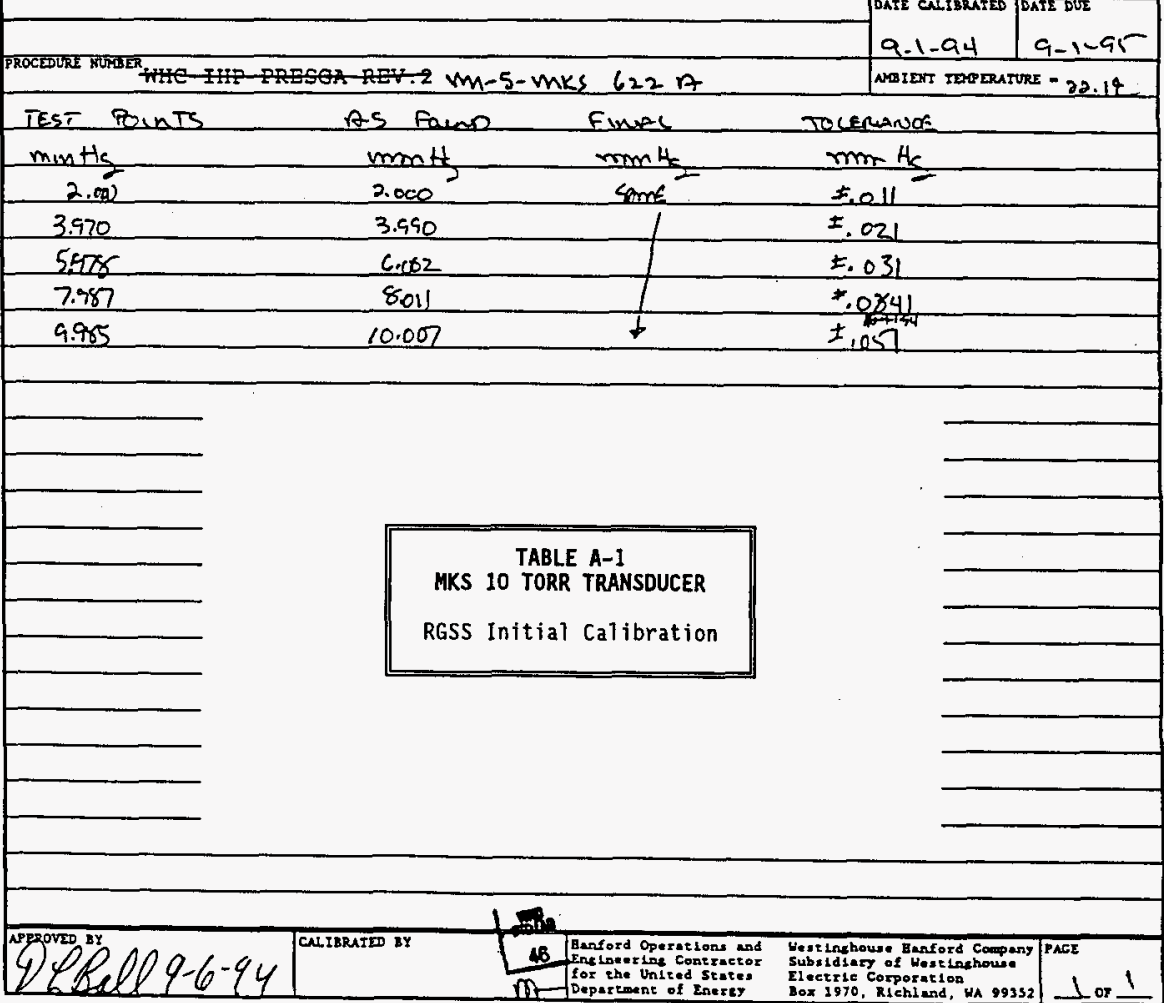


WESTINGHOUSE STANDARDS LABORATORY PUYSICAL AND ELECTRICAL REPORT

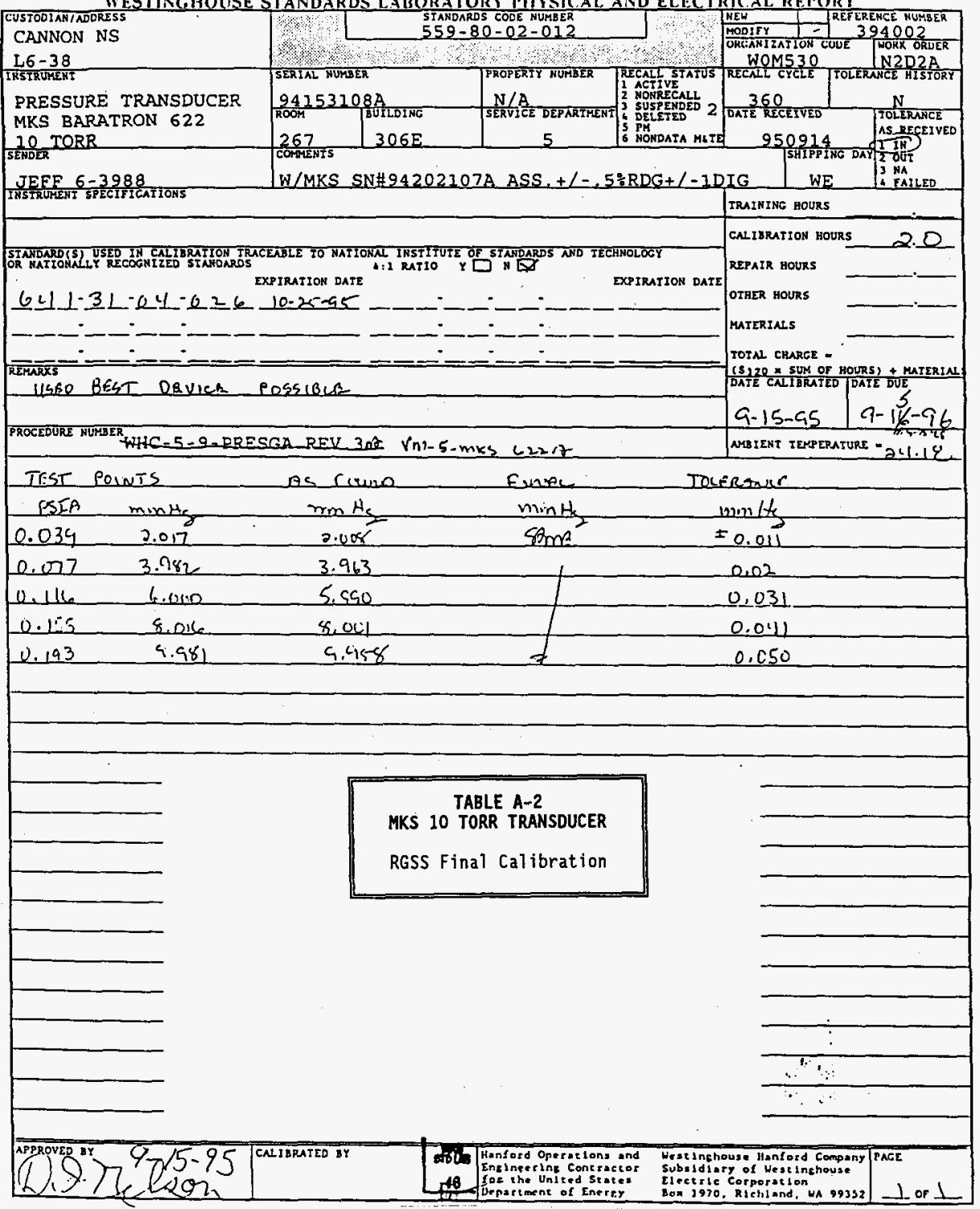


WHC-SD-WM-ATR- 137

Rev. 1

Page A-5

WESTINGHOUSE STANDARDS LABORATORY PHYSICAL AND ELECTRICAL REPORT

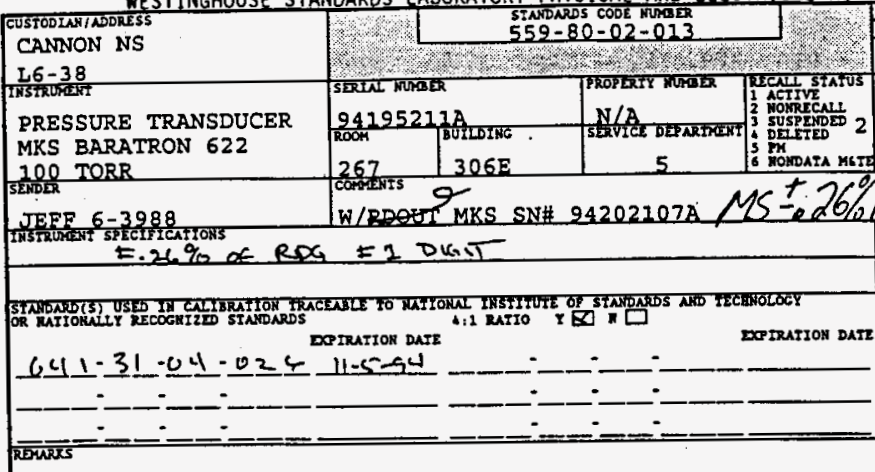

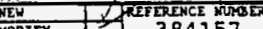

\begin{tabular}{|l|l|}
\hline MODIFY & 384157 \\
\hline ORGANLLAIION CODE & WON ORDET \\
\hline
\end{tabular}

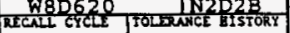

360

DAtह

240819 AS NECE

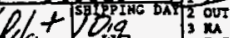
$3 \mathrm{mi}$

murarse noons

enctarution hotrs

REPATR BOTRS

OTEIX noons

mitrotats

rOTAL CHATEE -

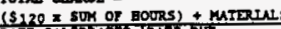
DATE CALIDUFL TDATE DUE

9-1-94 9.1-55

HIT-IHP-PRESGA-REV.2 VM-5.MKS l2LA

\begin{tabular}{|c|c|c|c|c|}
\hline TEST & Pounts & Ps founo & Fune & TOERAUEe \\
\hline pse & mm4 & $\mathrm{rmol}$ & $\mathrm{mm}$ tt & mm th \\
\hline .4 & 20.19 & 20.64 & stunt & $=.05^{3}$ \\
\hline .749 & 4.67 & 41.35 & & \pm .11 \\
\hline 1.058 & 62.05 & 6210 & & 5.16 \\
\hline 1.5986 & 82.72 & 82.78 & 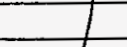 & \pm .22 \\
\hline 1.055 & 103.40 & 103.37 & I & \pm .27 \\
\hline
\end{tabular}

TABLE A-3

MKS 100 TORR TRAKSDUCER

RGSS Initial Calibration

\begin{tabular}{|l|l}
\hline APPROVED BY & CNLYARATED BY
\end{tabular}

Qe.8.989.6.94

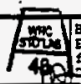

Hentord Operationd and

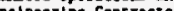

West Lhehouse Banford Company PACE

Subiditers of Weatineboute

jepicterat of Enerey

Box 1970 . Richland, wa 99352 20 


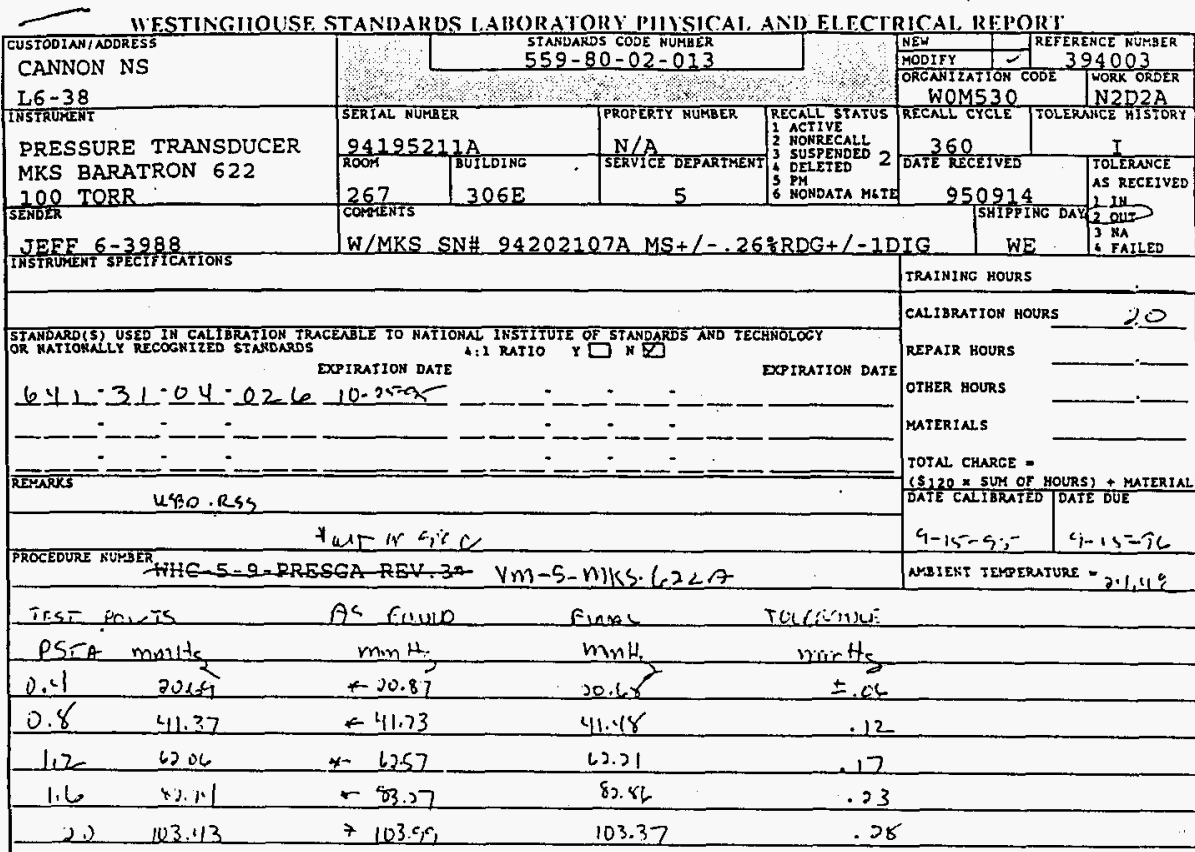

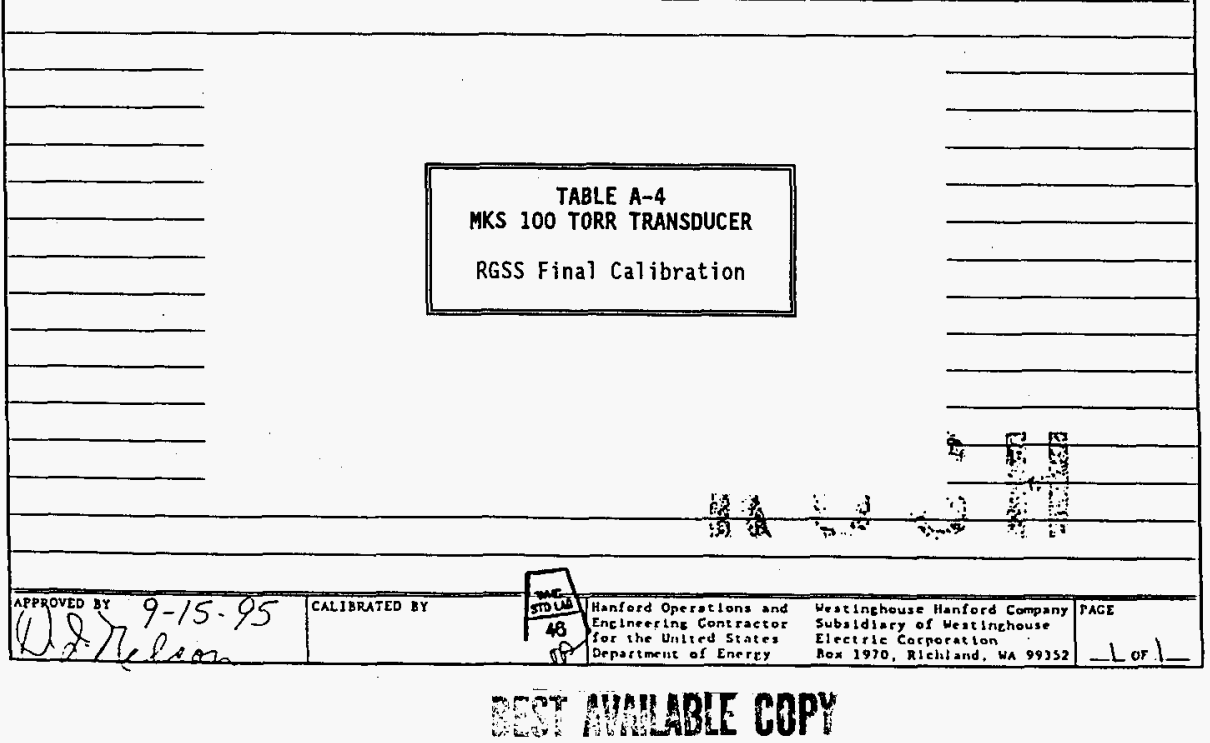


WESTINGHOUSE STANDARDS LABORATORY PHYSICAL AND ELECTRICAL REPORT

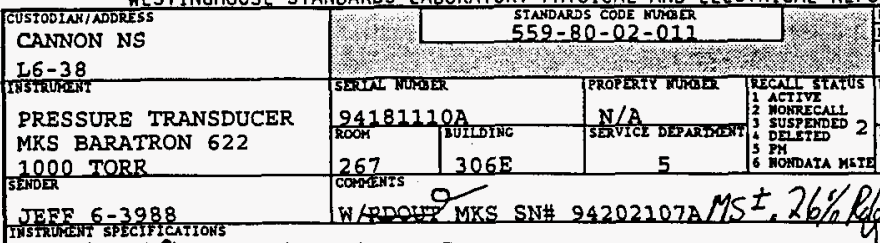

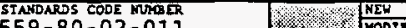

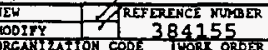

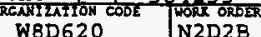
N2D2B $46-38$

PRESSURE TRANSDUCER

MKS BARATRON 622

1000 TORR

Tis

$F-26 \%$ of ROG $=1$ DIST

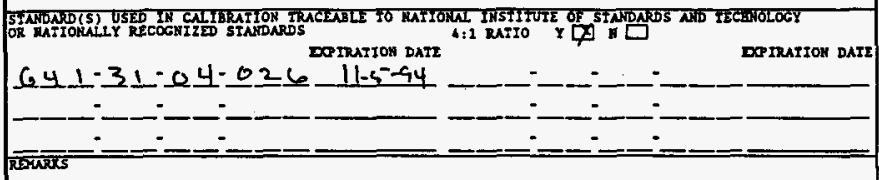

ruiturme gooss

rutrine bouss

CALIMRATIOA zoOns 2.0

REPATR EOURE

orters nours

Materints

rotal canecE -

(5)20 × SUM of HOURS) + MATERTAL DATE CNIIMAIE DATE bVE

9-1-54 9.1-55

PROCEURE WRER NDTENT TDPERATURE $=24.54$

\begin{tabular}{|c|c|c|c|c|}
\hline TEST & Pownis & As fann & Exros & TDLFR \\
\hline PSE & musts & monlts & $\mathrm{mall}_{2}$ & $\mathrm{mms}$ \\
\hline 4 & 3068 & 206.9 & simn & \pm .5 \\
\hline 8 & 413.7 & 414.4 & & \pm 1.1 \\
\hline 12 & 620.5 & 621.6 & & \pm 1.6 \\
\hline 16 & $8 \pi .4$ & 828.4 & & $\pm_{22}$ \\
\hline 19 & 9825 & 9832 & 7 & \pm 2.6 \\
\hline
\end{tabular}

TABLE A-5

MKS 1000 TORR TRANSBUCER

RGSS Initial Calibration 


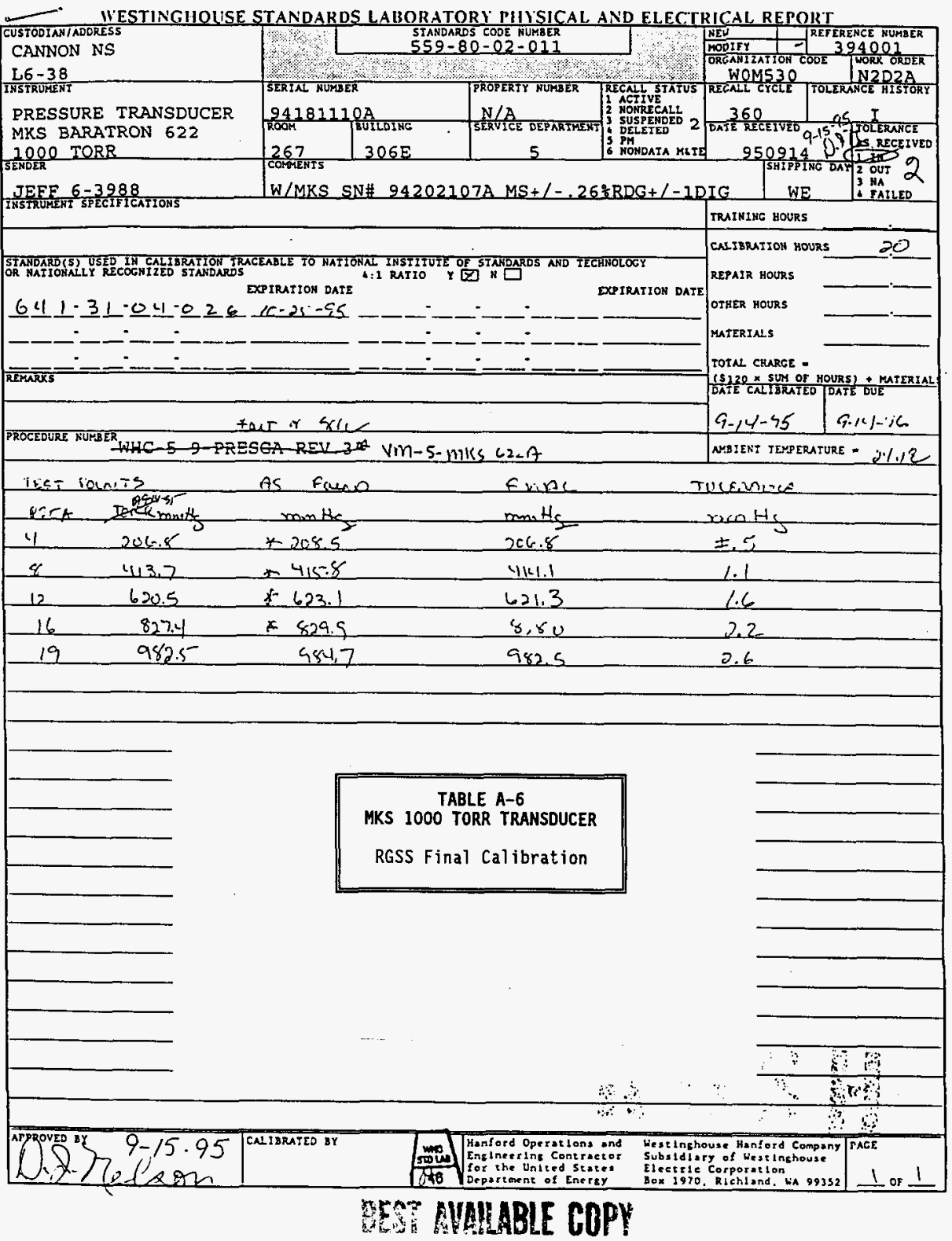


W HEY BRUCE E

T6-09

IHSTRLET:

DATA ACQUSN SYSTEM

H-P 3497A

CONTROL UNIT SENDER

$M$ CASTO 6-5013

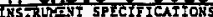

SEE TOLERANCE COLUMN

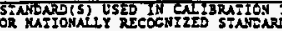

ECENLL TO MATIO

W.1 INSTISTIE OF

S.

$835-67-11-001$

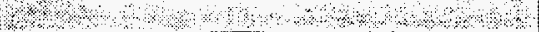

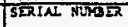

Domition patr

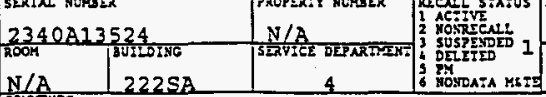

EROM $305 E$ FOR 222SA BE HEY

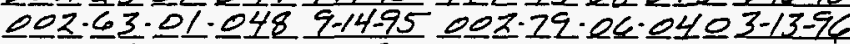

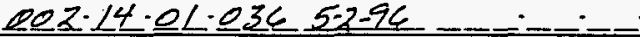

(WP-16)

2ROCELTE KMTBCR WHiC - 67-11-3497A(12-82)
ICAL REPORT

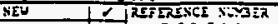

MODIFY 12164 W75980

E29305

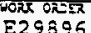

360 360
950530

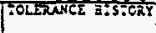

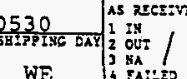

TRATMING EOURS Calizarion Botrs $<.5$ RIPAIR BOURS orese gours MATERIAIS ootal cansez -

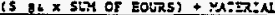

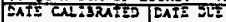
5-30-95| $5-30-96$ nSIEN :arenatidx -710

\section{TABLE A-7}

HP-3497A DACU

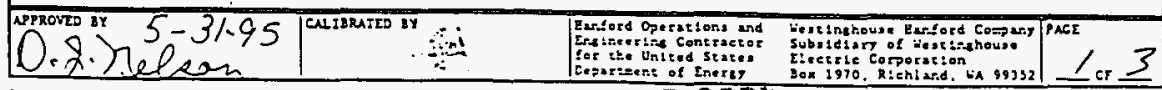

娄 
TABLE A-8

RGSS Thermocouples

A11 thermocouples (except Channel 10) were from P0 WFJ-XVV-257890 (Vendor:ARI)

\begin{tabular}{||l|l|l|l|l||}
\hline TC Assy. No. & Probe SN & Description & $\begin{array}{l}\text { RT Loop Res. } \\
\text { (ohms) }\end{array}$ & $\begin{array}{l}\text { RT Ins Res. } \\
\text { (ohms) }\end{array}$ \\
\hline \hline TC Channel 1 & 24961 & Ext. Bottom & 15.5 & $4 \times 10^{10}$ \\
\hline TC Channel 2 & 24967 & Ext. Bottom & 15.3 & $3 \times 10^{9}$ \\
\hline TC Channe1 3 & 24950 & Ext. Side & 15.4 & $7 \times 10^{11}$ \\
\hline TC Channel 4 & 24962 & Ext. Side & 15.5 & $3 \times 10^{10}$ \\
\hline TC Channel 5 & 24969 & Ext. Top & 15.7 & $6 \times 10^{9}$ \\
\hline TC Channel 6 & 24977 & Ext. Top & 15.3 & $1 \times 10^{11}$ \\
\hline TC Channel 7 & 24940 & 2nd Vol. & 15.5 & $6 \times 10^{11}$ \\
\hline TC Channel 8 & 24959 & 2nd Vol. & 15.5 & $4 \times 10^{9}$ \\
\hline TC Channe1 9 & 24960 & Cross Line & 15.3 & $9 \times 10^{10}$ \\
\hline TC Channe] 10 & $\begin{array}{l}\text { Stores } \\
\text { Standard } \\
\text { Type K }\end{array}$ & Cabinet & NA & NA \\
\hline
\end{tabular}

*At 500 volts.

TABLE A-9

Out-of-Specification Pressure Transducer Calibration Results

\begin{tabular}{|c|c|c|c|c|c|c|c|}
\hline \multicolumn{8}{|c|}{ MKS Recalibration on 9-15-95 } \\
\hline \multicolumn{4}{|c|}{ MKS 100 Torr Transducer } & \multicolumn{4}{|c|}{ MKS 1000 Torr Transducer } \\
\hline $\begin{array}{l}\text { Test } \\
\text { Value } \\
\text { (Torr) } \\
\end{array}$ & $\begin{array}{l}\text { Trans. } \\
\text { Result } \\
\text { (Torr) } \\
\end{array}$ & $\begin{array}{l}\text { Error } \\
\text { (Torr) }\end{array}$ & $\begin{array}{c}\text { Error } \\
(\%)\end{array}$ & $\begin{array}{l}\text { Test } \\
\text { Value } \\
\text { (Torr) }\end{array}$ & $\begin{array}{l}\text { Trans. } \\
\text { Result } \\
\text { (Torr) }\end{array}$ & $\begin{array}{l}\text { Error } \\
\text { (Torr) }\end{array}$ & $\begin{array}{c}\text { Error } \\
(\%)\end{array}$ \\
\hline 20.69 & 20.87 & 0.18 & 0.87 & 206.8 & 208.5 & 1.7 & 0.82 \\
\hline 41.37 & 41.73 & 0.36 & 0.87 & 413.7 & 415.8 & 2.1 & 0.51 \\
\hline 62.06 & 62.57 & 0.51 & 0.82 & 620.5 & 623.1 & 2.6 & 0.42 \\
\hline 82.74 & 83.27 & 0.53 & 0.64 & 827.4 & 829.9 & 2.5 & 0.3 \\
\hline 103.43 & 103.99 & 0.56 & 0.54 & 982.5 & 984.7 & 2.2 & 0.22 \\
\hline
\end{tabular}


TABLE A-10

Potential Pressure Error Effect on $\mathrm{Hg}$ Pump Measured Gas Quantity This Table is only for RGSS tests where $P$ was measured using the 100 Torr Transducer. It is assumed the
maximum error of +2.6 Torr $\left(0.35 \mathrm{KPa}\right.$ ) occurred in the calculation of the pressure difference $P_{f}-P_{\text {. }}$ (see maximum error of +2.6 Torr $(0.35 \mathrm{KPa}$ occurred in the calculation of the pressure difference Pf
Equation 4$)$. The effect of this error on the measured gas quantity is evaluated in this Table.

\begin{tabular}{|c|c|c|c|c|c|c|}
\hline Test ID & $\begin{array}{l}P_{f}-P_{v} \\
(\mathrm{KPa}) \\
\end{array}$ & $\begin{array}{l}\text { Error } \\
0.35 /\left(P_{f}-P_{v}\right) \\
(\%) \\
\end{array}$ & $\begin{array}{l}\text { Starting } \\
\text { Inj. Gas } \\
\text { a STP } \\
\text { (mL) } \\
\end{array}$ & $\begin{array}{l}\text { Initial } \\
\text { Hg Pump } \\
\text { Measured } \\
\text { Gas @STP } \\
\text { (mL) } \\
\end{array}$ & $\begin{array}{l}\text { Corrected } \\
\text { Hg Pump } \\
\text { Measured } \\
\text { Gas QSTP } \\
\text { (mL) } \\
\end{array}$ & $\begin{array}{l}\text { Corrected } \\
\text { Error } \\
\\
(\mathrm{mL})\end{array}$ \\
\hline RGS-001 & 63.61 & 0.55 & 37.80 & 40.76 & 40.54 & 2.74 \\
\hline RGS-003 & 59.09 & 0.59 & 38.69 & 37.91 & 37.69 & -1.00 \\
\hline RGS-005 & 59.57 & 0.59 & 36.99 & 38.17 & 37.95 & 0.96 \\
\hline RGS-006 & 56.43 & 0.62 & 37.46 & 36.49 & 36.26 & -1.20 \\
\hline RGS-025 & 62.21 & 0.56 & 37.62 & 33.67 & 33.48 & -4.14 \\
\hline RGS-026 & 49.49 & 0.71 & 37.70 & 33.80 & 33.56 & -4.14 \\
\hline RGS-027 & 27.61 & 1.27 & 20.12 & 18.85 & 18.61 & -1.51 \\
\hline RGS-028 & 11.68 & 3.00 & 10.02 & 7.85 & 7.61 & -2.41 \\
\hline RGS-029 & 1.0 & 35.00 & 2.52 & 0.68 & 0.44 & -2.08 \\
\hline RGS-033 & 51.04 & 0.69 & 37.11 & 34.79 & 34.55 & -2.56 \\
\hline RGS -035 & 22.05 & 1.59 & 20.11 & 16.70 & 16.43 & -3.68 \\
\hline RGS-036 & 21.35 & 1.64 & 20.09 & 14.88 & 14.64 & -5.45 \\
\hline RGS-037 & 45.16 & 0.78 & 35.36 & 30.81 & 30.57 & -4.79 \\
\hline RGS-038 & 2.22 & 15.77 & 2.55 & 1.51 & 1.27 & -1.28 \\
\hline RGS-039 & 3.44 & 10.17 & 5.11 & 2.73 & 2.45 & -2.66 \\
\hline RGS-043 & 2.03 & 17.24 & 5.04 & 2.43 & 2.01 & -3.03 \\
\hline RGS-045 & 1.53 & 22.88 & 5.04 & 2.05 & 1.58 & -3.46 \\
\hline RGS-046 & 1.27 & 27.56 & 3.77 & 1.85 & 1.34 & -2.43 \\
\hline RGS-047 & 11.17 & 3.13 & 20.14 & 7.46 & 7.23 & -12.91 \\
\hline RGS -048 & 9.49 & 3.69 & 10.06 & 6.50 & 6.26 & -3.80 \\
\hline RGS-049 & 8.91 & 3.93 & 10.14 & 6.10 & 5.86 & -4.28 \\
\hline RGS-050 & 3.32 & 10.54 & 5.04 & 2.27 & 2.03 & -3.01 \\
\hline RGS-051 & 30.58 & 1.14 & 25.7 & 21.0 & 20.76 & -4.94 \\
\hline RGS-052 & 37.53 & 0.93 & 28.1 & 25.5 & 25.26 & -2.84 \\
\hline RGS-053 & 30.19 & 1.16 & 25.3 & 20.8 & 20.56 & -4.74 \\
\hline
\end{tabular}




\section{APPENDIX B}

Ammonia Solution Analysis (ASA)

Analysis of the sample gas for ammonia was performed using a technique described in detail in the RGSS proof test report WHC-SD-WM-TRP-232 (TRP). The actual technique used during acceptance testing was modified to match the new RGSS hardware.

Briefly, after sample gas has been dumped into the evacuated 2 nd Volume (2ndV) of the extractor as part of gas quantification testing, the $2 \mathrm{ndV}$ is isolated, and 30 to $50 \mathrm{~mL}$ of a slightly acidic solution is injected into it. This solution absorbs the ammonia and retains it (even when exposed to air) while a transfer of the solution is made to the ion probe (0rion 9512BN Ammonia Gas Sensing Electrode) testing container. From the solution's measured ammonia concentration, solution volume, gas volume, gas temperature and pressure, the original percentage of ammonia in the sample gas can be calculated.

By way of example, the ammonia test for RGS-008 will be described step by step. This test was performed 7-17-95, and at 4:07 PM the final pressure in the 2nd Volume $(320.64 \mathrm{~mL})$ was measured at $2.16 \mathrm{KPa}$ with its temperature at $25.7{ }^{\circ} \mathrm{C}$. Then the $2 \mathrm{ndV}$ was isolated by closing valves $\mathrm{R}$ and $\mathrm{S}$ (see Figure 2 ); valve $Q$ was opened allowing $40.3 \mathrm{~mL}$ of $0.02 \mathrm{M} \mathrm{H}_{2} \mathrm{SO}_{4}$ to be drawn into the $2 \mathrm{ndV}$. After about a half hour, this solution was drawn out through valve $U$ and placed in a glass container for subsequent analysis.

The ammonia analysis was performed on 7-19-95 starting at 8:30 AM. First the ion probe was calibrated using two $\mathrm{NH}_{4} \mathrm{Cl}$ solutions of concentrations $10^{-8} \mathrm{moles} / \mathrm{mL}$ and $10^{-5} \mathrm{moles} / \mathrm{mL}$ as standards. With the ion probe immersed in a standard, a $\mathrm{pH}$ adjusting chemical was added to drive the solution basic ( $\mathrm{pH}$ between 12 and 14), releasing the ammonia to the probe. After the calibration of the probe was set with the two standards, a third calibration solution of $10^{-6} \mathrm{moles} / \mathrm{mL}$ was tested which gave a result of $1.02 \times 10^{-6} \mathrm{moles} / \mathrm{mL}$, verifying the ion probe calibration. The RGS-008 sample solution was then $\mathrm{pH}$ adjusted with the ion probe in place, giving a result of $2.35 \times 10^{-7}$ moles $/ \mathrm{mL}$.

The total number of ammonia moles in the sample solution would then be the solution volume multiplied by the concentration; i.e. $(40.3 \mathrm{~mL} \times 2.35 \times$ $\left.10^{-7} \mathrm{moles} / \mathrm{mL}\right)$, or $9.47 \times 10^{-6}$ moles of ammonia. The original number of moles of gas in the 2nd Volume before ammonia absorption can be calculated from the pressure and temperature using the perfect gas law:

$$
\begin{aligned}
n & =\left[(2.16 \mathrm{KPa})^{\star}(320.64 \mathrm{~mL})\right] /[(8.31441 \mathrm{~J} /\{\mathrm{mol} * \mathrm{~K}\}) *(273+25.4) \mathrm{K}] \\
& =2.7915 \times 10^{-4} \text { moles }
\end{aligned}
$$


Thus, the ammonia percentage (NH3\%) of the original gas is

$$
\mathrm{NH} 3 \%=9.47 \times 10^{-6} / 2.7915 \times 10^{-4} \times 100 \%=3.39 \text { percent }
$$

In the RGSS proof test report (WHC-SD-WM-TRP-232), ammonia proof testing had produced excellent results. The average of 17 tests of the same gas (5.14\% ammonia) was 5.07 percent ammonia, with a standard deviation of 0.3 percent. For RGSS acceptance testing, a new gas supply (vendor specified at 5.02 percent ammonia) was procured, and another series of tests were performed using the same methods as were done for the TRP. The results from these tests are given here in Table B-1. For each of seven tests, the ammoniated test solution was divided into two samples, $A$ and $B$.

The testing order was reversed for the $B$ samples, helping to reduce a possible testing order bias. However, it can be noted that slightly higher results were obtained as testing progressed. There was a reassuring correlation between the $A$ and $B$ series tests; for example, D-1 produced the highest results in both test series, and D-5 the lowest.

The combined average result of 5.05 percent ammonia for both test series compares favorably with the expected value of 5.02 percent. The combined average standard deviation of 1.15 percent is much higher than that experienced in the proof testing, but well within the requirements of the FRD. Only the individual test $D-1 B$ exceeded the FRD requirement of \pm 2 percent, absolute; this test was for the lowest quantity of gas tested $(0.6 \mathrm{~mL})$.

However, as previously discussed in Ammonia Solution Analysis Section (7.2.2.1), the RGSS acceptance test results for ammonia averaged 3.17 percent (see Table 16) where 5.02 percent was expected. A number of possible reasons are discussed there for this apparent degradation in accuracy when moving from proof testing to the RGSS acceptance testing. 


\begin{tabular}{|c|c|c|c|c|c|}
\hline \multicolumn{6}{|c|}{$\begin{array}{c}\text { TABLE B-1 } \\
\text { Preliminary MIX\#1 Ammonia D-Se }\end{array}$} \\
\hline $\begin{array}{l}\text { Test } \\
\text { ID }\end{array}$ & $\begin{array}{l}\text { Test } \\
\text { Order }\end{array}$ & $\begin{array}{l}\text { Gas Start } \\
\text { Pressure } \\
\text { (Torr) }\end{array}$ & $\begin{array}{l}\text { STP Gas } \\
\text { Volume } \\
\text { (mL) }\end{array}$ & $\begin{array}{l}\text { Measured } \mathrm{NH}_{3} \\
\text { Molar } \\
\text { Percentage }\end{array}$ & $\begin{array}{l}\text { Expected } \mathrm{NH}_{3} \\
\text { Molar } \\
\text { Percentage }\end{array}$ \\
\hline D-1A & 1 & 12.0 & 0.61 & 6.72 & 5.02 \\
\hline$D-2 A$ & 2 & 48.3 & 2.41 & 5.75 & 5.02 \\
\hline$D-3 A$ & 3 & 99.4 & 5.08 & 4.08 & 5.02 \\
\hline$D-4 A$ & 4 & 188.2 & 9.41 & 5.94 & 5.02 \\
\hline$D-5 A$ & 5 & 250.2 & 12.84 & 3.30 & 5.02 \\
\hline$D-6 A$ & 6 & 399.7 & 19.74 & 4.65 & 5.02 \\
\hline$D-7 A$ & 7 & 750.1 & 38.36 & 4.24 & 5.02 \\
\hline \multicolumn{4}{|r|}{ Average $=$} & 4.95 & \\
\hline \multicolumn{4}{|c|}{ Standard Deviation = } & 1.12 & \\
\hline$D-1 B$ & 14 & 12.0 & 0.61 & 7.27 & 5.02 \\
\hline$D-2 B$ & 13 & 48.3 & 2.41 & 6.13 & 5.02 \\
\hline$D-3 B$ & 12 & 99.4 & 5.08 & 4.34 & 5.02 \\
\hline$D-4 B$ & 11 & 188.2 & 9.41 & 5.42 & 5.02 \\
\hline$D-5 B$ & 10 & 250.2 & 12.84 & 3.47 & 5.02 \\
\hline$D-6 B$ & 9 & 399.7 & 19.74 & 4.94 & 5.02 \\
\hline $\mathrm{D}-7 \mathrm{~B}$ & 8 & 750.1 & 38.36 & 4.40 & 5.02 \\
\hline \multicolumn{4}{|r|}{ Average $=$} & 5.14 & \\
\hline \multicolumn{4}{|c|}{ Standard Deviation $=$} & 1.17 & \\
\hline
\end{tabular}


Included in this appendix are the raw data sheets for all RGSS acceptance tests that were successfully performed, and which provided data used in this report. These tests are summarized by test type in the following table

\begin{tabular}{|c|c|c|c|c|}
\hline Hardware & $\begin{array}{l}\text { Dry } \\
\text { Injection }\end{array}$ & $\begin{array}{l}\text { Wet } \\
\text { Injection }\end{array}$ & $\begin{array}{l}\text { Full } \\
\text { Simulation }\end{array}$ & $\begin{array}{l}\text { Sampler } \\
\text { Aging }\end{array}$ \\
\hline \multirow{2}{*}{$\begin{array}{l}\text { Extractor } \\
\text { Volume } \\
6-27-95\end{array}$} & RGS-001 & RGS-025 & RGS-051 & RGS-055 \\
\hline & RGS-003 & RGS-026 & RGS-052 & RGS-056 \\
\hline \multirow{17}{*}{$\begin{array}{l}\text { Extractor- } \\
\text { Sampler } \\
\text { Intergration } \\
\text { Test } \\
7-14-95 \\
\end{array}$} & RGS-005 & RGS-027 & RGS-053 & RGS-057 \\
\hline & RGS-006 & RGS-028 & & RGS-058 \\
\hline & $A-1$ & RGS-029 & & \\
\hline & $A-2$ & RGS-033 & & \\
\hline & RGS-008 & RGS-034 & & \\
\hline & RGS-009 & RGS-035 & & \\
\hline & RGS-020 & RGS-036 & & \\
\hline & RGS-022 & RGS-037 & & \\
\hline & & RGS-038 & & \\
\hline & & RGS-039 & & \\
\hline & & RGS-043 & & \\
\hline & & RGS-045 & & \\
\hline & & RGS-046 & & \\
\hline & & RGS-047 & & \\
\hline & & RGS-048 & & \\
\hline & & RGS-049 & & \\
\hline & & RGS-050 & & \\
\hline
\end{tabular}


THIE 1

EXTRCTOR VOLUME HEASUREMENT TABLE

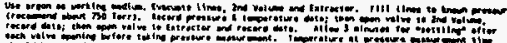

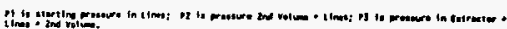

IIST DATE $6-27-45$

IEST OE SCRIPIION:

Test Performer N.S.Genves

Arcepbence Test

Messured zad voluma $=230.0$

recewereats-

\begin{tabular}{|c|c|c|c|c|c|c|c|c|}
\hline Test & $\begin{array}{l}\text { PI } \\
\text { Press. } \\
\text { (Torr) }\end{array}$ & 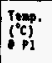 & $\begin{array}{l}\text { Pz } \\
\text { Press: } \\
\text { (Torr) }\end{array}$ & (exp. & $\mid \begin{array}{c}\text { Pross. } \\
\text { Prourr) }\end{array}$ & (Ten & $\operatorname{lima}_{\substack{\text { Lolum } \\
\text { vec }}}^{*}$ & $\begin{array}{l}\text { Extractor } \\
\text { volime } \\
(\mathrm{te})\end{array}$ \\
\hline 1 & 1721.4 & 20.9 & 2942 & 209 & 84.1 & 21.0 & 220.4 & 1350.0 \\
\hline 2 & 706.0 & 21.2 & 288.3 & 21.2 & 82.4 & 21.3 & 220.9 & 1351.5 \\
\hline 3 & 754.4 & 21.8 & 307.8 & $26 \bar{\theta}$ & 87.8 & 21.1 & 220.5 & $135+.4$ \\
\hline$A$ & 794 & 22.5 & 306.0 & 22.5 & 87.5 & 22.6 & 220.7 & 1350.6 \\
\hline 5 & $72 x .0$ & 23.0 & 296.8 & 23.1 & 85.0 & $2 s, 1$ & 221.5 & 1948 \\
\hline 6 & 724.4 & 23.2 & 285.7 & 23.2 & 84.8 & 23,2 & 221.0 & 1340.7 \\
\hline 7 & 7306 & 23.3 & 298.6 & 23.3 & 85.5 & 23.3 & 221.2 & 1348.9 \\
\hline 8 & 723.2 & 23.4 & 295.4 & 23.4 & 845 & 23.4 & 221.0 & 1350.2 \\
\hline 7 & 736.4 & 23.5 & 300.8 & 23.5 & 86.1 & 23.5 & 221.0 & $13+9.0$ \\
\hline 10 & 748.8 & 23.5 & 305.8 & 23.5 & 87.6 & 23.5 & 220.9 & 1347.3 \\
\hline & & & & & & & & - \\
\hline & & & & & & & & \\
\hline & & & & & & & & \\
\hline
\end{tabular}

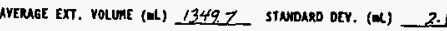

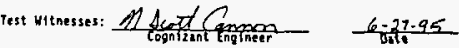

$$
\text { B.Q.从uy }
$$

Thate :

EXTMCTON/SNIPLE INTECRUTIOM TEST

-

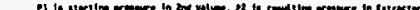

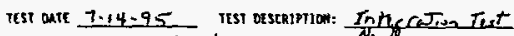
Test purforeer $C$ Knught a.

\begin{tabular}{|c|c|c|c|c|c|c|}
\hline \multicolumn{2}{|c|}{ 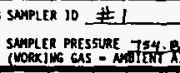 } & \multicolumn{5}{|c|}{ 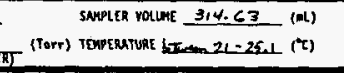 } \\
\hline $\begin{array}{l}\text { TEST } \\
\text { TYPE }\end{array}$ & $\begin{array}{l}\text { ISsT } \\
\text { step }\end{array}$ & IIME & $(x)$ & $\begin{array}{c}\text { Sensor } 1 \\
\text { (1000) } \\
\text { (Torr) }\end{array}$ & $\begin{array}{c}\text { Sensor } \\
(1000)^{2} \\
(10 r r)\end{array}$ & $\begin{array}{c}\text { Senser }^{3} \\
\text { [100) } \\
\text { (loorm) }\end{array}$ \\
\hline \multirow[t]{7}{*}{ SPT } & Zero & $9: 310$ & 25.1 & .05 & 0006 & .006 \\
\hline & Leak Test Sturt & $2: 32$ & 25.1 & 25 & dol & .006 \\
\hline & Leak Test find & 9.42 & $2 \times 1$ & .06 & 017 & .017 \\
\hline & extructor stert & $2: 46$ & 25.1 & 20,32 & $=$ & $=$ \\
\hline & Extrextor find & $9: 51$ & 25.1 & 90.38 & $=$ & $=$ \\
\hline & 2ng vol, stimt & 552 & $25: 1$ & 16.95 & 16.542 & $=$ \\
\hline & 2nd Yol, End & $3: 07$ & 95.1 & 16.96 & 16.956 & $=$ \\
\hline
\end{tabular}

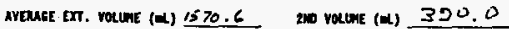

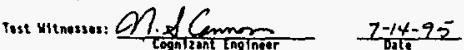
B.f. Hug

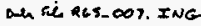


RCS.001

Thete

injection test DATA SHEE

TEST DATE 6-29-95 Test performer N.S. CandeN

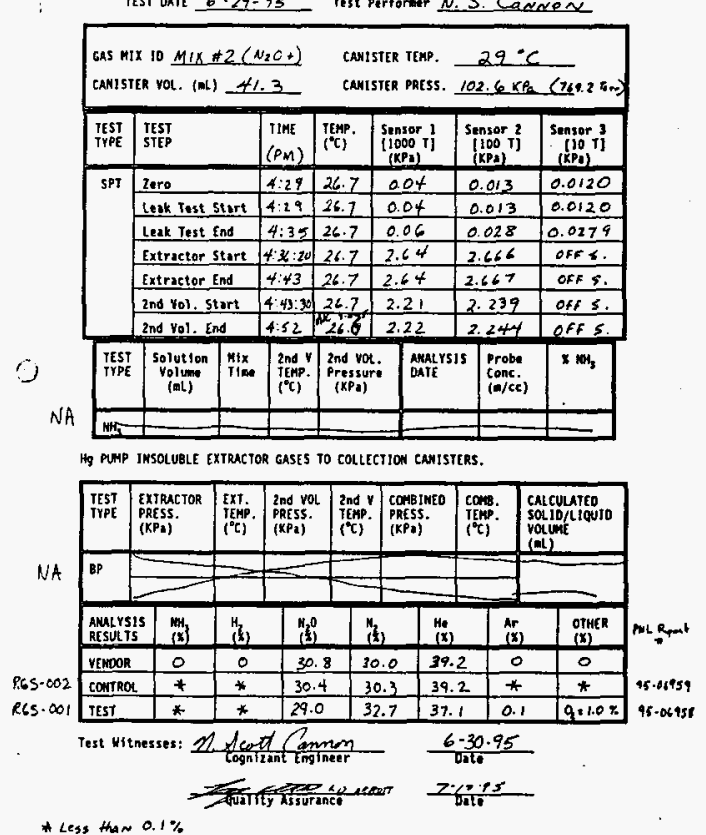

$\overline{R G S .003}$

THEL,

IMJECT IOW TEST DATh SHEt

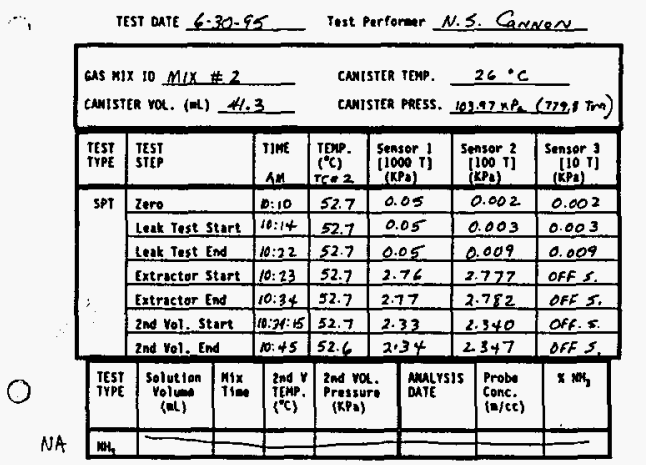

ng purp insaluate extracion gases to coltection canisters.

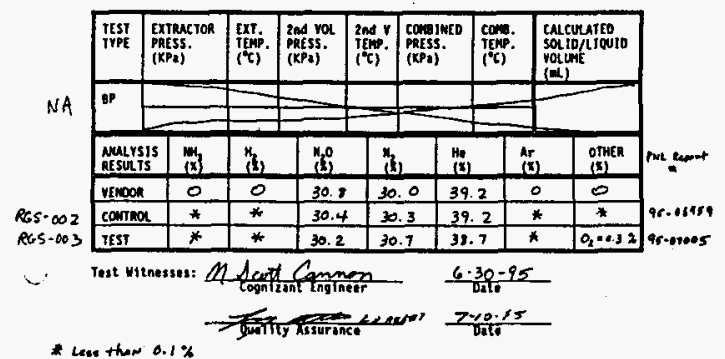

\section{BFST MUALABLE COPY}


TMELE 3

IMJECTIOW ICST DATA SHEET

7

TEST OATE $7-1 /-95$

Test perfomer N.S. Canvers

GAS MIX ID MUYA $1(\mathrm{NH},+)$ CANISTER TEMP. $28^{\circ} \mathrm{C}$

CANISTER VOL. (mL) 4.3

CAMISTER PRESS. IOSO7KP (790.5 Tom)

\begin{tabular}{|c|c|c|c|c|c|c|}
\hline $\begin{array}{l}\text { TEST } \\
\text { TYPEE }\end{array}$ & $\begin{array}{l}\text { IESI } \\
\text { SICP }\end{array}$ & IIME & $\begin{array}{l}\text { TENP. } \\
\left({ }^{\circ} \mathrm{C}\right)\end{array}$ & 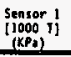 & 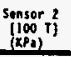 & 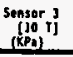 \\
\hline \multirow[t]{7}{*}{ SPI } & Zero & $2: 50 \mathrm{em}$ & 25.0 & 0.05 & 0.014 & 0.0138 \\
\hline & 1edk Test Start & $2: 55$ & 280 & 0.05 & $0.0,4$ & 0.0138 \\
\hline & Leak Test fnd & $3: 05$ & 28.0 & 0.09 & 0.067 & 0.0662 \\
\hline & Extractor Start & 3:0:30 & 28.1 & 2.62 & 2.637 & UfF 5 \\
\hline & Extractor End & $3: 18$ & 28.0 & 2.59 & 2.621 & of 5 \\
\hline & 2nd Yol. Start & $3: 19$ & 28.0 & 2.21 & 2.237 & OffS \\
\hline & 2nd Vol. End & $3: 29$ & 28.0 & 2.24 & 2.267 & off 5 \\
\hline
\end{tabular}

0

\begin{tabular}{|c|c|c|c|c|c|c|c|}
\hline $\begin{array}{l}\text { TEST } \\
\text { TYPE }\end{array}$ & $\begin{array}{c}\text { Solut ion } \\
\text { volume } \\
\text { (mL) }\end{array}$ & $\begin{array}{l}\text { pix } \\
\text { Time }\end{array}$ & $\begin{array}{l}2 \mathrm{2nd} Y \\
\text { IfHP. } \\
\text { (c) }\end{array}$ & $\begin{array}{l}\text { 2nd vot. } \\
\text { Pressure } \\
\text { (KFs) }\end{array}$ & $\begin{array}{l}\text { aMaLYSIS } \\
\text { DATE }\end{array}$ & $\begin{array}{l}\text { Probe } \\
\text { conc. } \\
\text { (n/cc) }\end{array}$ & $x \mathbb{N}_{1}$ \\
\hline NH, & 52.3 & $3: 31$ & 28.0 & 2.267 & $7-\{3 \cdot 15$ & LeYvid & 2.1 \\
\hline
\end{tabular}

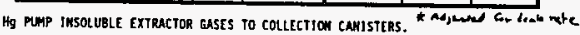

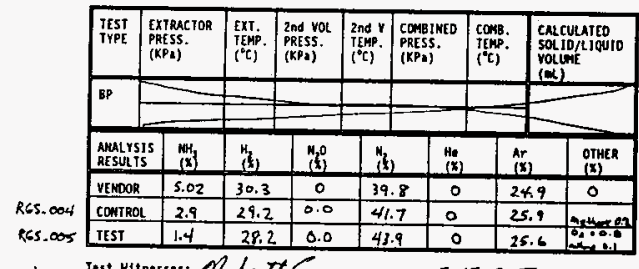

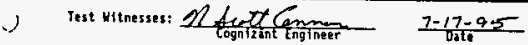

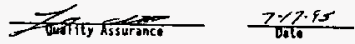

4 Comporter tine-abut 19 minats taed.

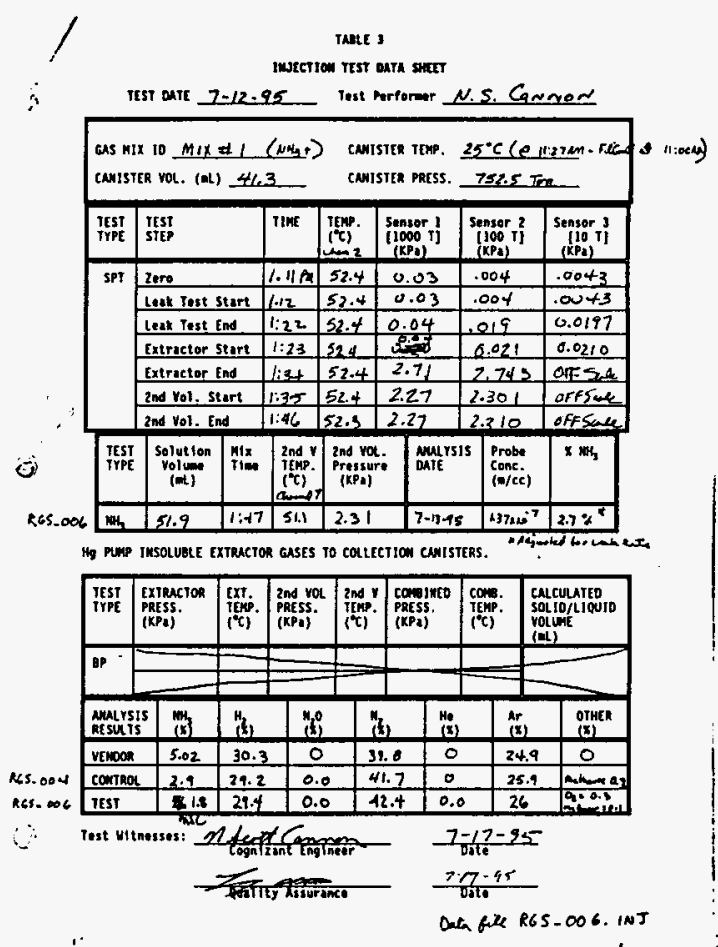




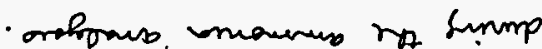

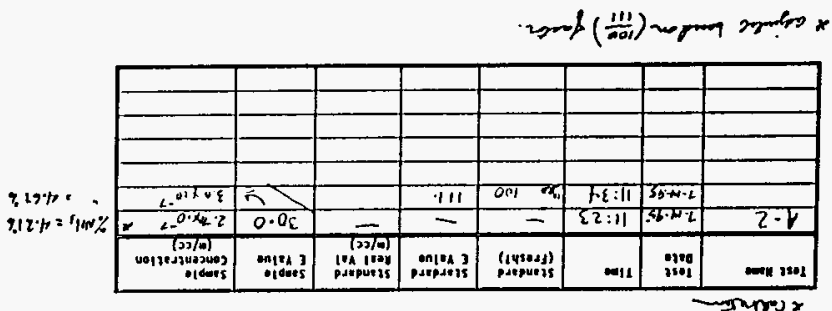

orpatioso no grivion ropl 1

LI I

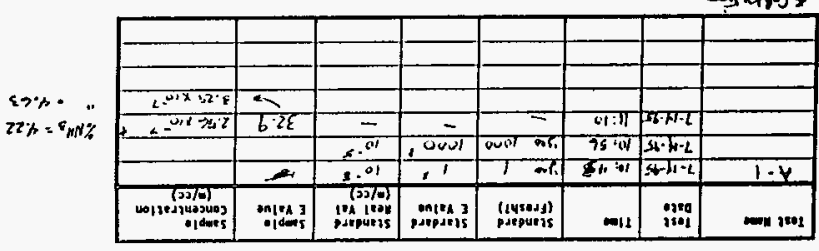

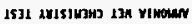

$$
\begin{aligned}
& \text { rin } \\
& 5 b-\angle 1-L
\end{aligned}
$$

$r v$

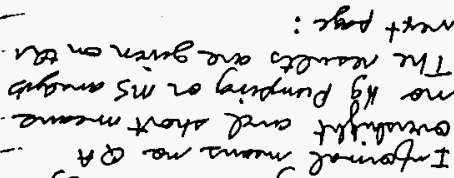
- $\left(s_{b}-11-2\right.$ us) Gumanos bo 2ho $3.05 \sim$ rio impure to

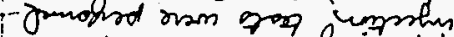

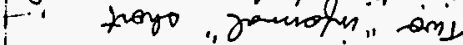

(.-

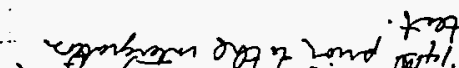
7 hose bunzgur da youndid - man min tro jens buren trotum on to tos $\mathrm{H}$, 20.0 in rmian juonot 207 to amanoo Yenusano y buron x $y$ हi tron - Nhip De try ginuzotyd ram - - Limjar onorod has sumery? 
TABLE 3

INUECTLOW TEST DATA SHET

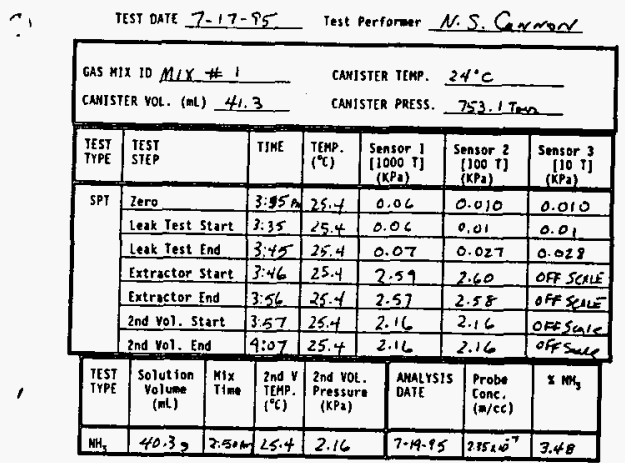

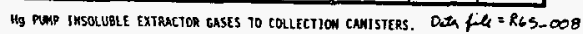

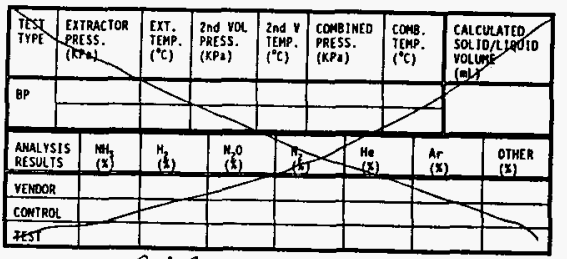

TABLE 3

wutetion Test Dath shet

Test aute 7-18-95, Test purformer N.S. Q GNnoN

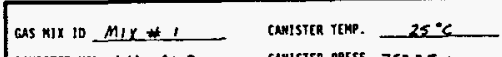

CNISTER YOL. (ML) 41.3

CWNISTER PRES5. 753.2TES

\begin{tabular}{|c|c|c|c|c|c|c|}
\hline $\begin{array}{l}\text { TEST } \\
\text { IYPt }\end{array}$ & $\begin{array}{l}\text { IEST } \\
\text { STEP }\end{array}$ & TIME & $\begin{array}{l}\text { IfRP. } \\
(t c)\end{array}$ & 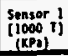 & $\begin{array}{c}\text { Sensor } 2 \\
{\left[\begin{array}{l}100 \\
(\mathrm{KP})\end{array}\right]}\end{array}$ & $\begin{array}{c}\text { Sensor } \\
{\left[10^{3}{ }^{3}\right.} \\
(\mathrm{KP}))^{3}\end{array}$ \\
\hline \multirow[t]{7}{*}{ SPT } & Lero & 9:06 & 524 & 0.06 & 0.014 & 0.015 \\
\hline & Leik rest st art & $9: 07$ & 52.4 & 0.06 & 0.013 & 0.014 \\
\hline & Leak Iest End & $9: 17$ & 52.5 & 0.09 & 0.044 & 0.045 \\
\hline & Extractor Sturt & $9: 18$ & 52.5 & 2.79 & 2.790 & oftesale \\
\hline & Extruttor End & $9: 20$ & 52.4 & 2.75 & 2.787 & orescale \\
\hline & 2nd vol. Start & 9:27 & 52.4 & 2.35 & 2.353 & oxf Suce \\
\hline & 2nd Vol. End & $8: 39$ & 52.5 & 2.37 & 2.368 & on sen \\
\hline
\end{tabular}

\begin{tabular}{|c|c|c|c|c|c|c|c|}
\hline $\begin{array}{l}\text { TEST } \\
\text { TYPEE }\end{array}$ & $\begin{array}{c}\text { Solut ian } \\
\text { volumit } \\
\text { (mt) }\end{array}$ & $\lim _{i \min }$ & $\begin{array}{l}\text { 2nd } y \\
\text { TEAP } \\
(\text { TC) }\end{array}$ & $\begin{array}{l}\text { 2nd yol. } \\
\text { Pressure } \\
\text { (KPa) }\end{array}$ & $\begin{array}{l}\text { Mulvs's } \\
\text { oule }\end{array}$ & \begin{tabular}{|l} 
Probe \\
tonc. \\
$(\boldsymbol{m} / \mathrm{ccc})$
\end{tabular} & $x \mathrm{~K}$ \\
\hline & & & & & & & \\
\hline
\end{tabular}

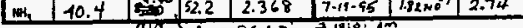

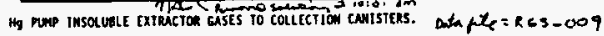

\begin{tabular}{|c|c|c|c|c|c|c|c|}
\hline trax & 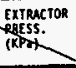 & $\exp _{(\boldsymbol{N})}$ & $\begin{array}{l}\text { 2nd yol } \\
\text { PRESs. } \\
\text { (KPa) }\end{array}$ & 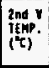 & 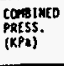 & $\begin{array}{l}\text { coses. } \\
\text { Tekp. } \\
\left(\rho^{\circ} c\right)\end{array}$ & 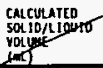 \\
\hline \multicolumn{8}{|l|}{ op } \\
\hline $\begin{array}{l}\text { NuLYYS } \\
\text { RESULTS }\end{array}$ & 影 & (3) & & & & & $\begin{array}{l}\text { OTHER } \\
(\mathbf{x})\end{array}$ \\
\hline Venoor & & & & & & & \\
\hline cournor & & & & & & & \\
\hline
\end{tabular}

\section{RCS-OD: IFT}

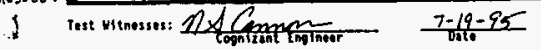

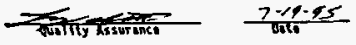


SIMUUNT ExTRUSION TEST DATA SHEET

TEST 10 RG2-020 TEST OATE 8-8-95 Test Derformer N.S. Cavnone

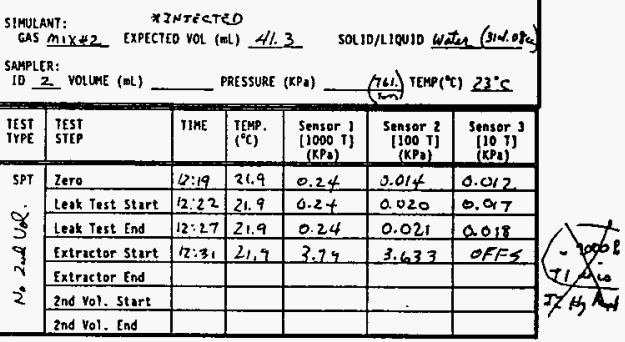

(i)

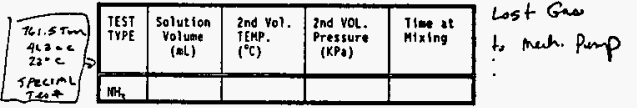

Hg PUMP Extractor gases to collection Cantsters.

Kax, PT4

(KPT) Cab. Temp

\begin{tabular}{|c|c|c|c|c|c|c|}
\hline $\begin{array}{l}\text { TEST } \\
\text { TYPE }\end{array}$ & $\begin{array}{l}\text { ExTRAGTOR } \\
\text { PRESS. } \\
\text { (KP I) }\end{array}$ & 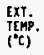 & $\begin{array}{l}\text { 2nd vol } \\
\text { PRESS. } \\
\text { (KFo) }\end{array}$ & $\begin{array}{l}\text { 2nd } y \\
\text { IEPP. } \\
\text { ("c) }\end{array}$ & $\begin{array}{l}\text { COABEINED } \\
\text { PRESS. } \\
\text { (KPA) }\end{array}$ & 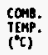 \\
\hline BT & & & & & & \\
\hline & & & & & & \\
\hline
\end{tabular}

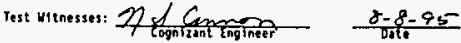

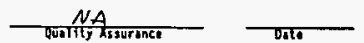

\section{BEST AVALALBLE COPY}

TANLE 3

INJECTION TEST DATA SHEt

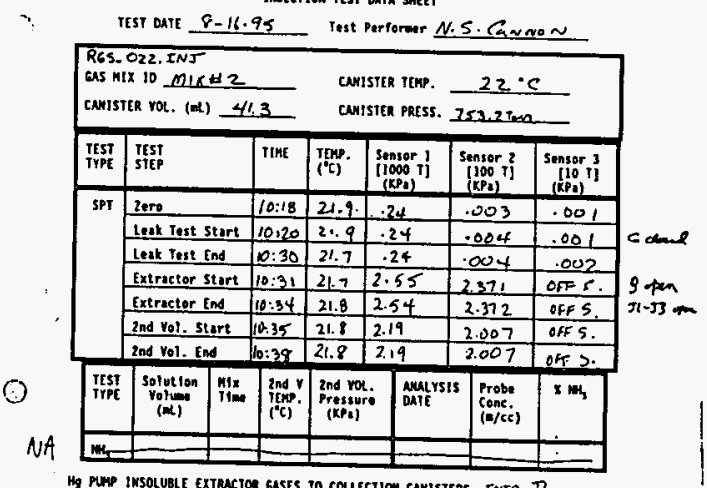

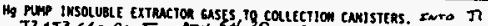

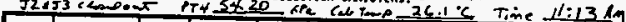

TEST ExTRACTOR ET

NA

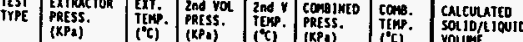

(1)

op

f

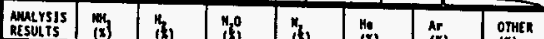

NSS-002

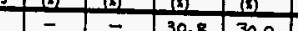

Vermoon

\begin{tabular}{l|l|l|l|l|l|l|l}
\hline ItSI & - & - & 30.4 & 30.3 & 39.2 & - & - \\
\hline
\end{tabular}

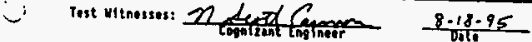

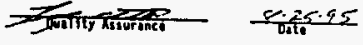




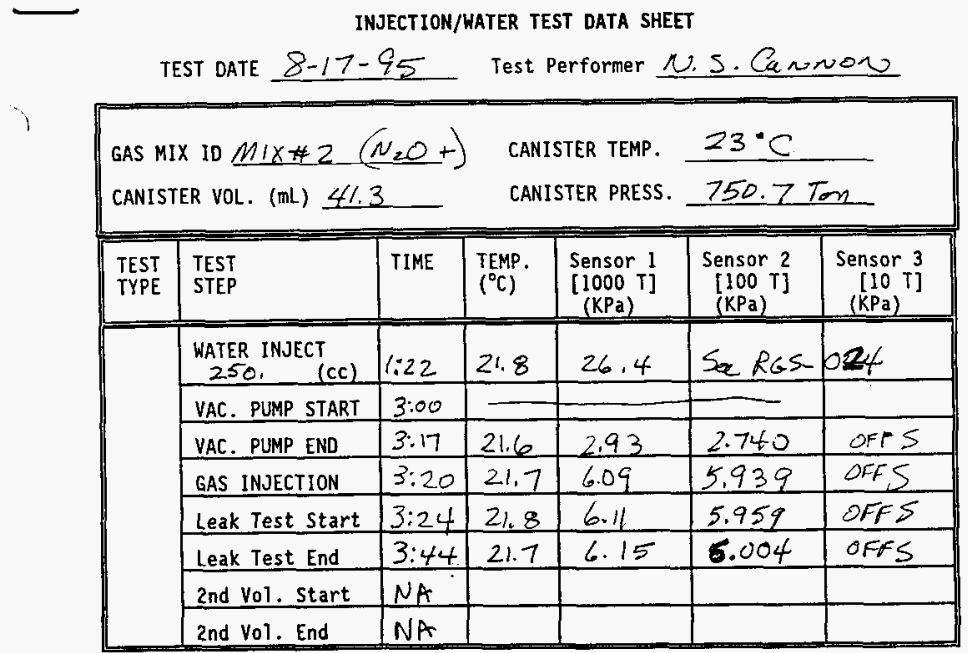

Hg PUMP INSOLUBLE EXTRACTOR GASES TO COLLECTION CANISTERS.

FINAL PTT4 65.52 (KPa) CAB. TEMP( $\left.{ }^{\circ} \mathrm{C}\right) 26.5$

FINISH TIME 4:20 PM

RGS-025. INW

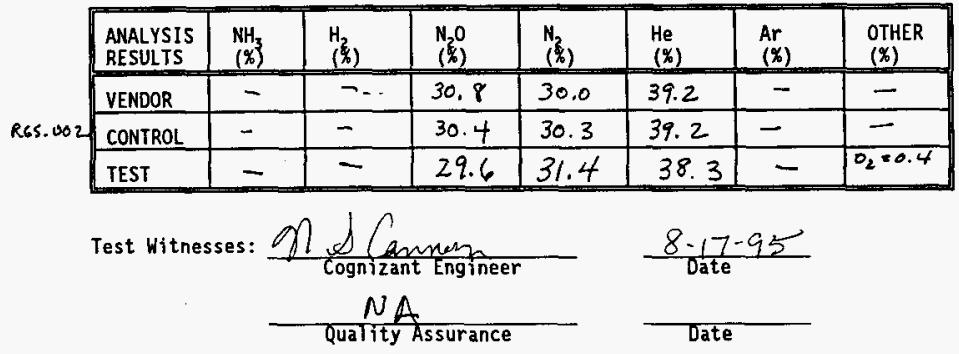


WHC-SD-WM-ATR - 137

Rev. 1

Page $c-9$
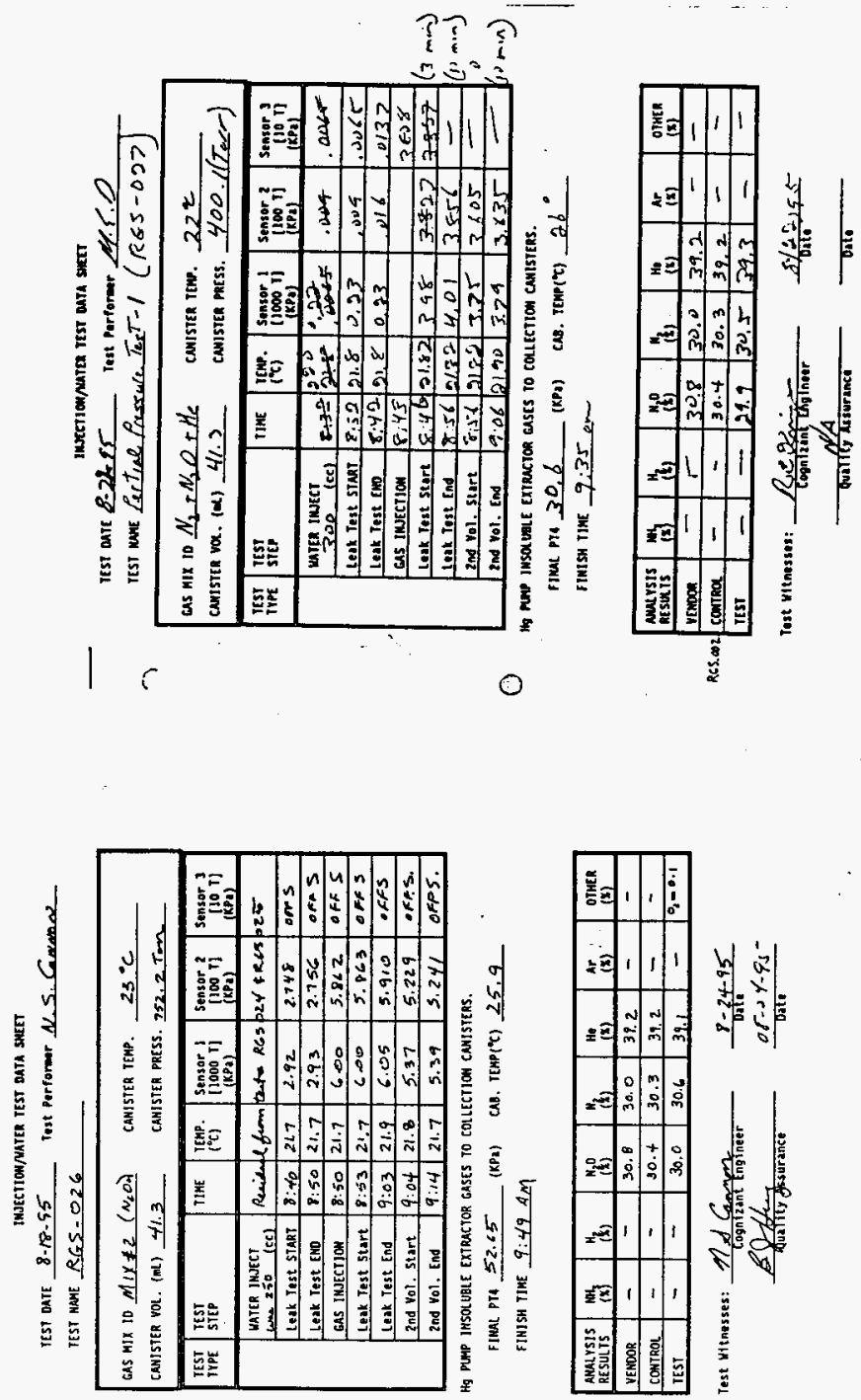

tran

Esis

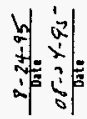

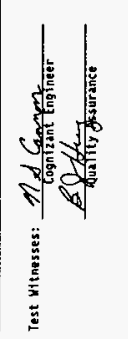

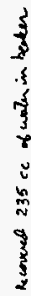

0 


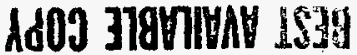

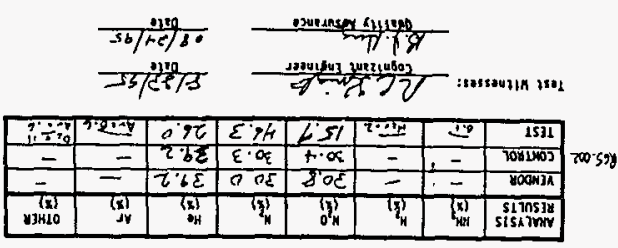

¿Г:

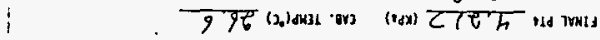

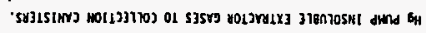

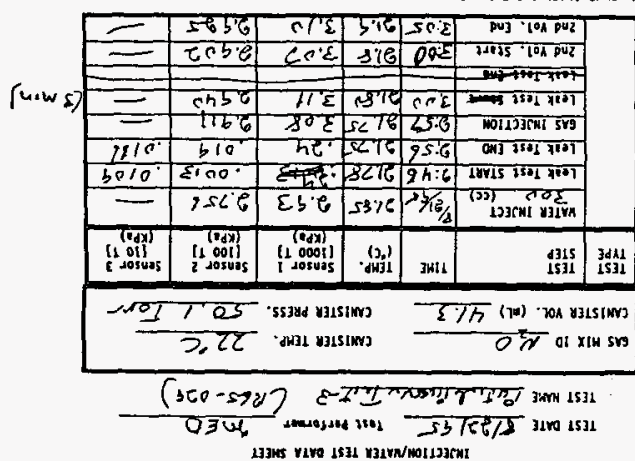

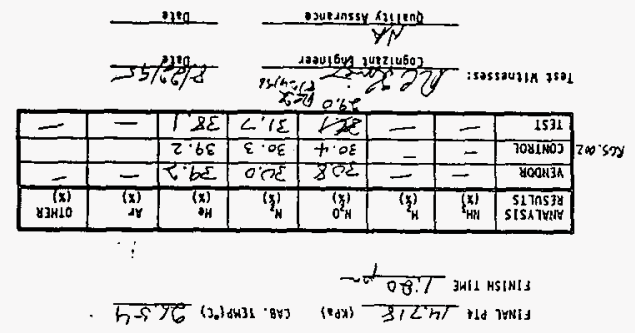

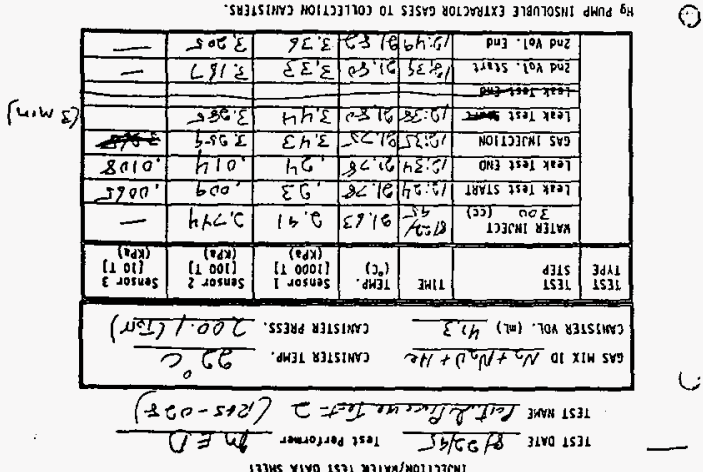

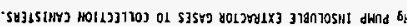


WHC-SD-WH-ATR- 137
ReV. 1

Page $C-11$

- Uluguest 24, 1995

argontist RGS-033

File ReS5236A

Tost givo Dample $413.3 \mathrm{cc}$

740.4 tor Ar gow $63^{\circ} \mathrm{C}$

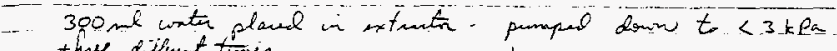
- thee diffurat times.

- Tpt etent 0202 value $K$ off, whe $T$ yene

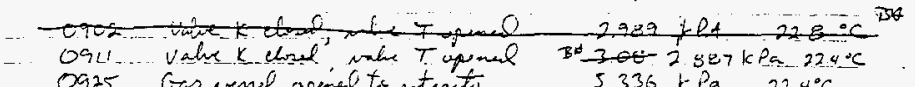

O925. Geo messel openes to extranter

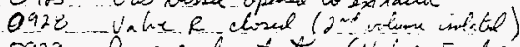

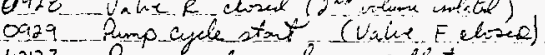

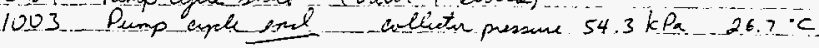

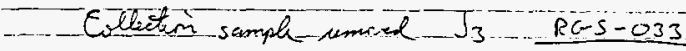

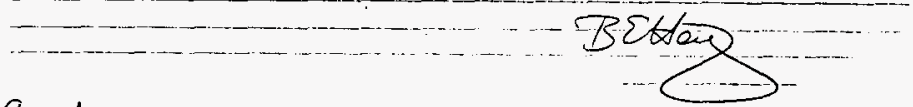

Auquest 20, 1995

a

Test gas $4130 \mathrm{c}, 400.0$ Tor Ar e $22^{\circ} \mathrm{C}$

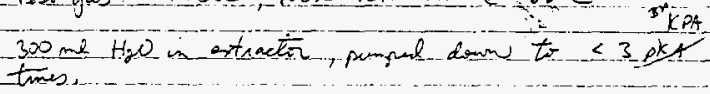

Int Stat 1L:45 vale $K$ atosed, value $T$ opened

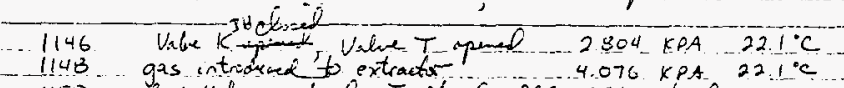

1150 gand volum che extractor $4.076 \mathrm{KPA} 22.1 \mathrm{C}$ Nithe $F$ close

- Stut of pamp.cyete

End ff pump arie -12:22

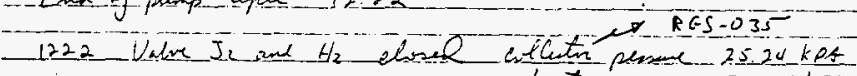

- estinter temp $321 \%$

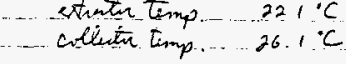

extrat presere 3.234 kPS

PO AWUABL COPY BEtang 


$$
\text { angout Test RGS }=036 \text {. File RGSSZ36C }
$$

Test gao $413 \mathrm{cc} 400.9$ Tor Are $23^{\circ} \mathrm{C}$

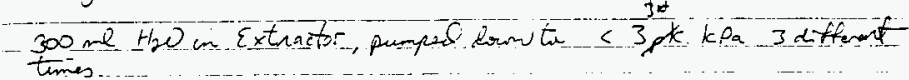

Tests Stant 000 Vahe $K$ Closed, value Yopened

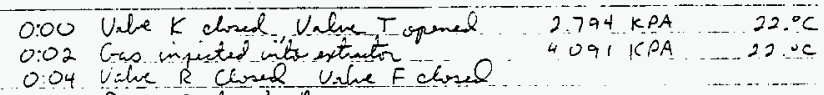

0.05 Dimp-Cych stast

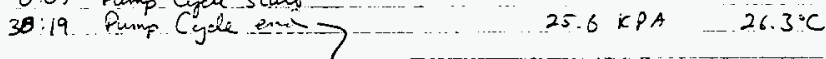

$\rightarrow R C S-036$ acawird
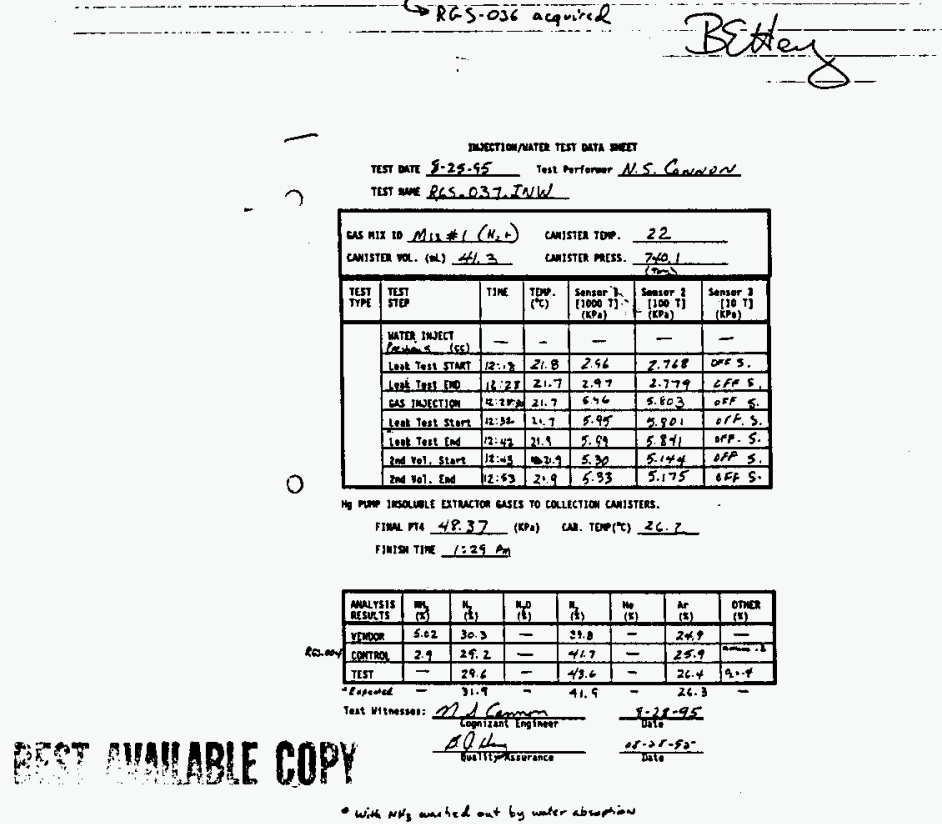
IMJECTLOM/MATER TEST DATA SHEtT

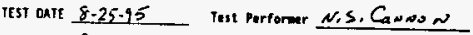

TEST NAME RGS-038. NNW

GAS WIX IO ARGON CANISTER TEAP. 22

CAMISTER VOL. (ML) 41.3 CANISTER PRESS. SO

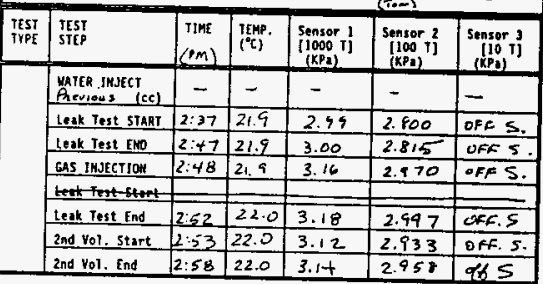

Hg PUNP insolvale cxtractor gases to COLLECTION CNistirs.

FIHA PTE 5.149 (KP1) CAB. TEMP("C) 26.8

FINISH TIME 3:11 PM

\begin{tabular}{|c|c|c|c|c|c|c|c|}
\hline $\begin{array}{l}\text { Aalys } 15 \\
\text { Besul is } \\
\end{array}$ & $\begin{array}{l}\mathrm{NH}_{3} \\
(\mathrm{x})\end{array}$ & (d) & Mo & (d) & $\begin{array}{l}M_{n} \\
\text { (x) }\end{array}$ & $\begin{array}{l}\text { Ar } \\
(x)\end{array}$ & $\begin{array}{l}\text { OTHER } \\
\text { (X) }\end{array}$ \\
\hline YEMOOR & & 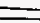 & -7 & - & 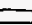 & & 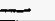 \\
\hline CONTROL & 4 & - & a- & - & $=$ & 99.95 & - \\
\hline TEST & 0.1 & 0.2 & 0.7 & 13.5 & - & 82.6 & $0_{1}=2,7$ \\
\hline
\end{tabular}

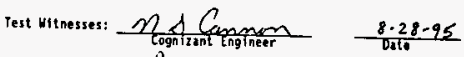

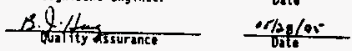

1

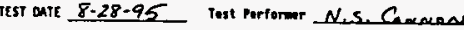

TEST MNE RGS.039. INW

Gas wIX 10 ARGON CNMISTER TEMP. $23^{\circ} \mathrm{C}$. CNISTER PRESS. $102.0 \mathrm{Tm}$

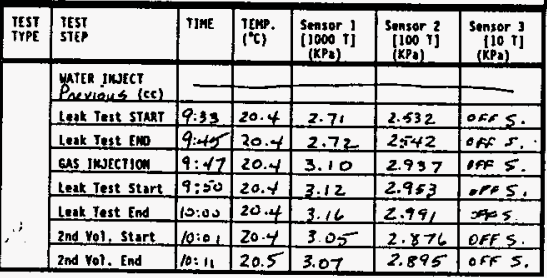

(i)

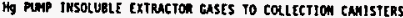

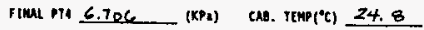

GINISH TIME 10:31 AM

\begin{tabular}{|c|c|c|c|c|c|c|c|c|}
\hline & $\begin{array}{l}\text { MaLYSIS } \\
\text { RESUIS }\end{array}$ & (x) & (3) & (4) & (4) & $\begin{array}{l}\mathrm{He} \\
\text { (3) }\end{array}$ & Ar & $\begin{array}{l}\text { OTHER } \\
(x)\end{array}$ \\
\hline & vewoon & - & & & & & & \\
\hline \multirow[t]{2}{*}{ RSS.032 } & CONTROL & 二 & - & $=$ & $=$ & $=$ & 99.95 & - \\
\hline & TEST & - & $=$ & .1 & 2.71 & - & 94.32 & $0, \times 0.8$ \\
\hline
\end{tabular}

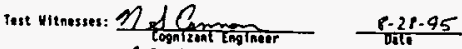

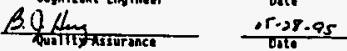

\section{BEST AVALLABLE COPY}


WHC-SD-WM-ATR- 137
ReV. 1

Rev. 1
Page $C-14$

-ivgent 29, 1295

Anpor Jest $R E S-\phi 33 A, \quad R E S-\varnothing 93 B$

Test $0=0$ File:_PCS_043.1\%U

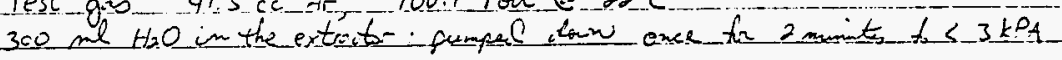

Test stat 0226

0 26 U.he K 2 inel

$2464 k f+201 C$

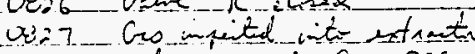

$2 .-272-k A_{3}$

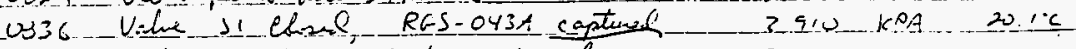
Q037. Values $T$, s upol $t$ int arlume ovis Pump_Cyche Stat -

2

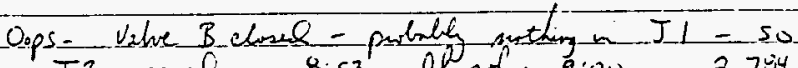

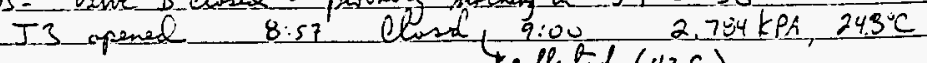
colleted (43C)

901 Pump-cexume - Muke F culosed

Perpopele dimpel fta 5 stintes

$4.2 k P .3 \quad 24.5^{\circ} \mathrm{C}$

J2- colluted - purper go_(43B)

BEtter

- Ang. 29 1995

Augir Test RGS- $\$ 45$

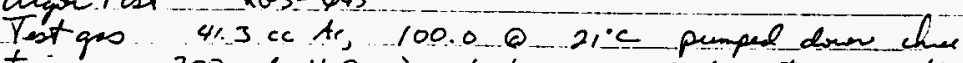

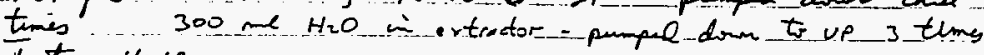
vest $1 /: 12$

chen

11:12 Ualue $K A T$ opend

11 15. Gos inisicted into extueter

$11: 18$ Value $R$ closel, Valve FCloses

$4.433 \mathrm{kPa}-19.9^{2} \mathrm{C}$

$J$, closed, $H_{1}$ 'closed

$2740 \mathrm{kPa} 19.9^{\circ} \mathrm{C}$

I:zo- Pump Cycle Stante

$11: 40 \quad \mathrm{~J}_{2}$ closed, $H_{2}$ chisel camista coilctel.

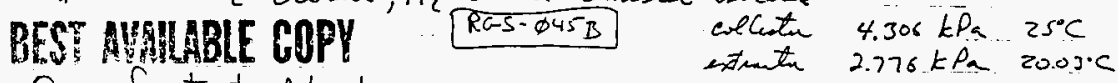
Oops - forgot to data log.
no file for this one.

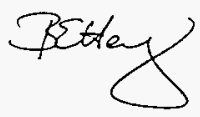


Cling. 19, 1995

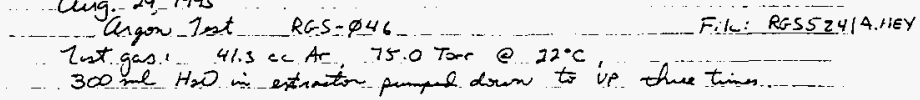

-.++-

Test Stant 12:30.

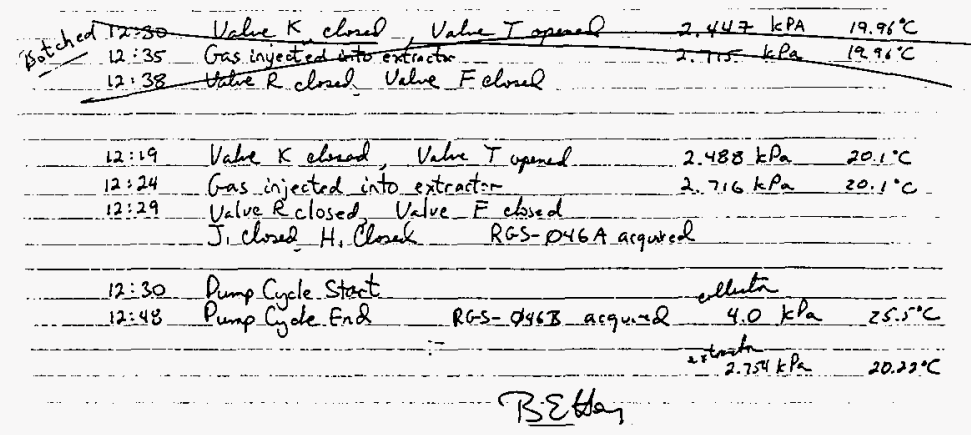

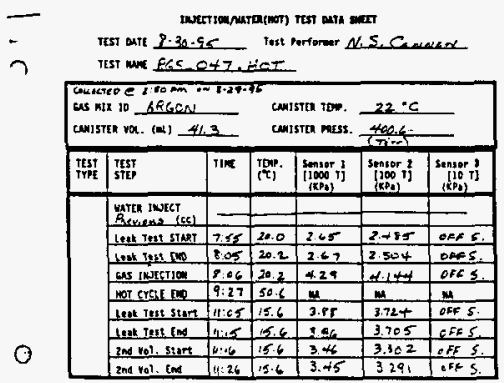

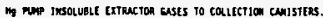

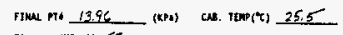

51HISH TIUE II: 57

\begin{tabular}{|c|c|c|c|c|c|c|c|}
\hline 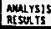 & 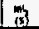 & (5) & 80 & (3) & $\stackrel{m}{\pi}$ & (a) & onimet \\
\hline 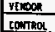 & $=$ & - & & $1-$ & - & 99.95 & $\bar{Z}$ \\
\hline & $1-$ & $=$ & $=$ & 0.3 & $\Rightarrow$ & 49.25 & \\
\hline
\end{tabular}

WE 


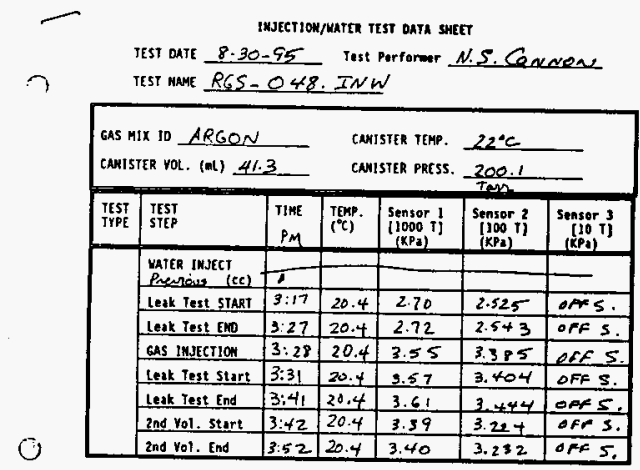

Hg PUMP INSOLUBLE EXTRACTOR GaSES IO COLLFCTION CANISTERS.

FIMAL P14 $\frac{12.302}{\text { (KP 1) CAl. TEMP("C) } 25.1}$

FIMISH IIME $4: 23$

\begin{tabular}{|c|c|c|c|c|c|c|c|}
\hline $\begin{array}{l}\text { AruLissIs } \\
\text { RESULIS }\end{array}$ & $\begin{array}{l}N+x_{3} \\
(x)\end{array}$ & (3) & $\begin{array}{l}\mathrm{H}_{0} \mathrm{O} \\
(\mathrm{B})\end{array}$ & (1) & $\begin{array}{l}\mathrm{He}_{0} \\
(x)\end{array}$ & $\begin{array}{l}A r \\
(x)\end{array}$ & $\begin{array}{l}\text { OTHER } \\
\text { (x) }\end{array}$ \\
\hline YENOOR & - & $=$ & - & & & & \\
\hline CONTROL & - & $=$ & $=$ & - & - & 99.95 & - \\
\hline TEST & - & - & - & 4.84 & 1.37 & 93.7 & - \\
\hline
\end{tabular}

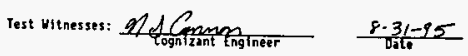

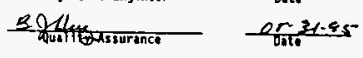

INJECTLOWNATER(Hot) TEST DATh shet

test oute 8-31-95 int performer N.5. Cancuene TEST nNe RGS-049.40T

GUS HIX ID ARCON CMMISTER TEAP. $22{ }^{\circ} \mathrm{C}$

CNister vor. (m) 4.3

CNHISTER PRESS. ZOLT

\begin{tabular}{|c|c|c|c|c|c|c|}
\hline TYST & $\begin{array}{l}\text { TEST } \\
\text { STEP }\end{array}$ & TIME & $\begin{array}{l}\text { Tenp. } \\
\langle(\tau)\end{array}$ & 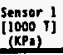 & 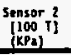 & 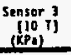 \\
\hline & $\begin{array}{l}\text { MATER IMJETT } \\
\text { (cC) }\end{array}$ & & & & & \\
\hline & Lenk Test SIART & $8: 19$ & 20.2 & 2.68 & 2.505 & off $s$. \\
\hline & Ient Teit Eno & $8: 29$ & 20.0 & 2.64 & 2.472 & . Fin \\
\hline & Gas INJECTIOH & $8: 30$ & 20.0 & 3.45 & 3.288 & off 5 . \\
\hline & WOT CrCLE ENO & $10: 05$ & 50.1 & M & $m$ & m \\
\hline & Leak Test Sturt & $11: 46$ & 19.7 & $3+49$ & 3.331 & off 5 . \\
\hline & Lenk Test End & $n: 56$ & 19.9 & 3.51 & 3353 & orer $S$ \\
\hline & 2nd yol, stert & $11: 57$ & 19.9 & 3.32 & $3.15 t$ & aff 5 \\
\hline & 2nd Yol. End & $12: 07$ & 19.9 & 3.32 & 3.161 & ores \\
\hline
\end{tabular}

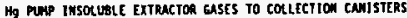

Ftmal Pra (XPs) CAB. $\operatorname{TEMP}(\mathrm{C})$

FiMISH VIHE

\begin{tabular}{|c|c|c|c|c|c|c|c|}
\hline $\begin{array}{l}\text { MULLYSIS } \\
\text { RESUSIS }\end{array}$ & mat & () & (1) & (3) & $\begin{array}{l}\mathrm{M}_{0} \\
\text { (x) }\end{array}$ & $\stackrel{A r}{(x)}$ & $\begin{array}{l}\text { OTHER } \\
\text { (y) }\end{array}$ \\
\hline retionen & & & & & & & \\
\hline comian & - & 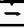 & - & - & - & 94.95 & - \\
\hline IESI & - & - & $=$ & 0.15 & - & 98.6 & $0,0.15$ \\
\hline
\end{tabular}

Test witnesses: $27 \times 1$ Gumer $8.31-95$ b) $\frac{\text { of }}{\text { of }-0-45}$ 


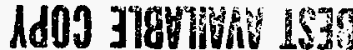

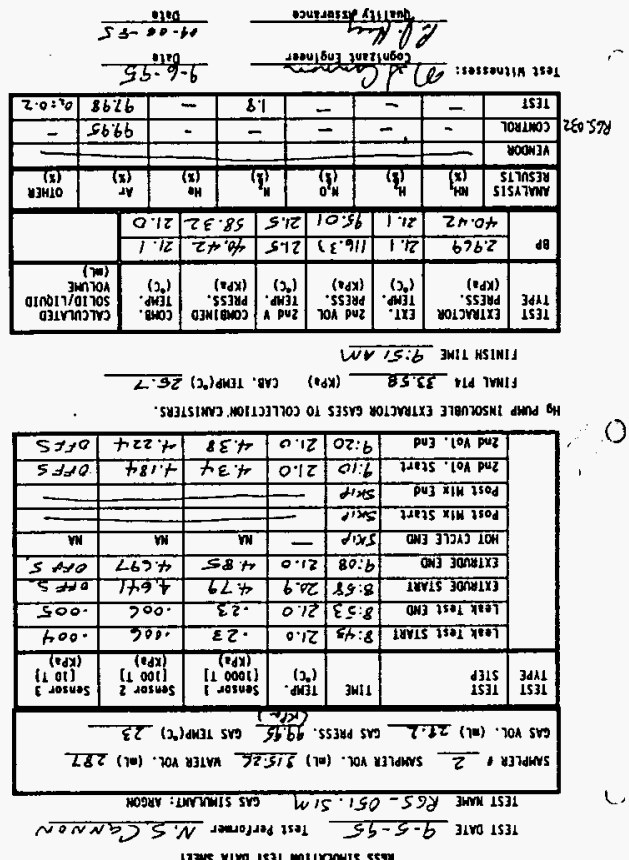

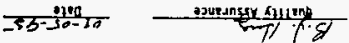

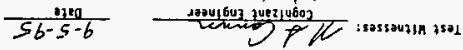

\begin{tabular}{|c|c|c|c|c|c|c|c|}
\hline 8.0 .10 & $8 E 26$ & - & $\varepsilon \%$ & $=$ & 10 & - & 1531 \\
\hline - & 5666 & $=$ & - & $=$ & - & - & 7041403 \\
\hline- & & & & & & - & עoGN3A \\
\hline $\begin{array}{r}\text { (8) } \\
83 \mathrm{H} 10\end{array}$ & $(x)$ & (x) & $7 \gamma_{\mathrm{H}}$ & $\begin{array}{l}(5) \\
0^{2} \mathrm{~W}\end{array}$ & (1) & $(x)$ & 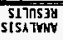 \\
\hline
\end{tabular}

$$
\text { we } \angle Z: Z 1 \text { 3wil Hsimls }
$$

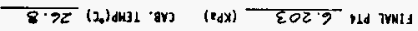

\begin{tabular}{|c|c|c|c|c|c|c|}
\hline$\leq 40$ & 1262 & $+1 \cdot \varepsilon$ & $L \cdot 02$ & $79: 21$ & Puy $10 \mathrm{~A}$ pul & \\
\hline 3910 & $E+b 7$ & $\pi 1^{2} \varepsilon$ & 9.02 & $25: 11$ & $2 A 215$ lon PUZ & \\
\hline 5910 & $8 \times 0.5$ & $22 \cdot \varepsilon$ & 5.02 & F5:11 & 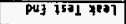 & \\
\hline 2589 & 910.8 & $1+\varepsilon$ & 5.07 & FA:II & 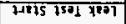 & \\
\hline Ww & in & W & 1.05 & fo:01 & ONI 375 J 104 & \\
\hline$-5=x 0$ & $\$ 10.8$ & $81 \cdot \varepsilon$ & 172 & ETis & 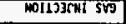 & \\
\hline$-5+150$ & $2+5 \cdot 2$ & 282 & 112 & 21.4 & 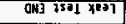 & \\
\hline $5 \times 10$ & 32,7 & $08 \cdot 2$ & 602 & 20.8 & TEVIS $7501 \times 107$ & \\
\hline & & & & & 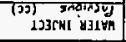 & \\
\hline 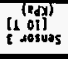 & 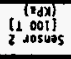 & 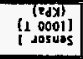 & $\begin{array}{l}\left(J_{0}\right) \\
d W 3 i\end{array}$ & 3NII & $\begin{array}{l}d 115 \\
1531\end{array}$ & $\begin{array}{l}3 d d 1 ! \\
15] 1\end{array}$ \\
\hline & $\frac{(-101)}{2 \cdot 001}$ & \multicolumn{2}{|c|}{$\begin{array}{l}\text { '553yd y3isimos } \\
\text { dHal yusiny }\end{array}$} & \multicolumn{3}{|c|}{ 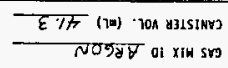 } \\
\hline & & & & 0 & $\overline{598}$ & \\
\hline
\end{tabular}

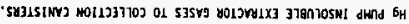

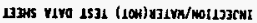




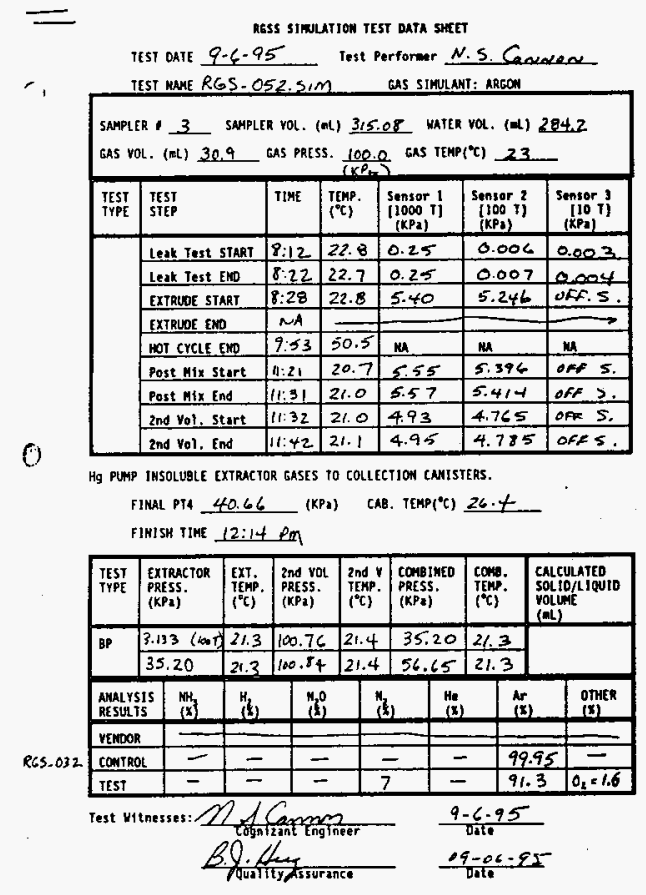

Ress strunution usst outh seet

TEST DUTE 9-8-95. Tost porformer N.5. C.

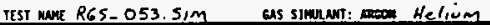
SAMPLR 1 2 SNAPLER VOL. (DI) 315.26 WAIER vOL. (II) 217.5

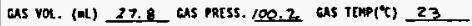

\begin{tabular}{|c|c|c|c|c|c|c|}
\hline$\underset{\text { IrST }}{\text { IrSPE }}$ & $\begin{array}{l}\text { Itst } \\
\text { stef }\end{array}$ & TIME & $\begin{array}{l}\text { toup } \\
\left({ }^{\prime}(c)\right.\end{array}$ & 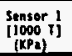 & 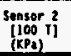 & $\begin{array}{c}\text { Sensor } 3 \\
110, \mathrm{~T} \\
(\mathrm{RPI})\end{array}$ \\
\hline & Leak Test STMRT & $7: 56$ & 22.1 & 0.25 & 0.003 & 0.001 \\
\hline & Leak Test en & $8: 06$ & 22.0 & 0.24 & 0.003 & 0.002 \\
\hline & EXTAUDE START I & 8.91 & 22.0 & 5.07 & 4.922 & OFFS \\
\hline & EXTRUDE EMO & & & & & \\
\hline & HOT CYCLE ENO & $9: 37$ & 51.3 & $\bar{M}$ & $m$ & $m$ \\
\hline & Post Mix start & $11: 04$ & 20.7 & 4.97 & $4.8+6$ & oxfs \\
\hline & Post Mix End & $11: 14$ & 20.9 & 5.01 & 4.869 & OfF 5 \\
\hline & 2nd vol. Stare & $31: 16$ & 20.9 & 4.48 & 4.329 & ort 5 \\
\hline & 2nd Yol. End & $11: 26$ & 21.0 & 4.51 & 4.358 & off 5 \\
\hline
\end{tabular}

()

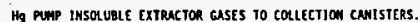

FIMLL PIA 33.40 (KPA) CAS. TEMP('C) 26.0 FINISH TIME $11: 59$

\begin{tabular}{|c|c|c|c|c|c|c|c|c|}
\hline 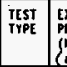 & $\begin{array}{l}\text { Extenctor } \\
\text { PRESS. } \\
\left(\begin{array}{l}\mathrm{KP} 1) \\
(000 \mathrm{~T})\end{array}\right.\end{array}$ & 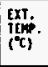 & $\begin{array}{l}\text { 2nd vol } \\
\text { PaEss. } \\
\text { (KPa) }\end{array}$ & 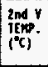 & & & cones. & 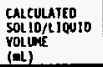 \\
\hline \multirow[t]{2}{*}{ Bp } & 3.21 & 21.2 & \multirow{2}{*}{$\begin{array}{l}100.63 \\
100.65\end{array}$} & 26.5 & \multicolumn{2}{|c|}{35.16} & 21.2 & \\
\hline & 35.16 & 21.2 & & 21.4 & \multicolumn{2}{|c|}{56.60} & 21.2 & \multirow[b]{2}{*}{$\begin{array}{l}\text { OTHER } \\
\text { (x) }\end{array}$} \\
\hline $\begin{array}{l}\text { MULLYSIS } \\
\text { RESULIS }\end{array}$ & $w_{(x)}$ & (3) & $n_{0} 0$ & & (b) & & $\hat{A r}_{(\mathrm{x}}$ & \\
\hline \multirow{2}{*}{ VEnoon } & $=$ & & & & & & & $=$ \\
\hline & - & - & - & \multicolumn{2}{|c|}{0.19} & 99.78 & 78 & - \\
\hline $\begin{array}{l}\text { COWTBOLL } \\
\text { TEST }\end{array}$ & $\overline{-}$ & - & $=$ & & .46 & 96. & .89 & $0_{\alpha}=0.47$ \\
\hline
\end{tabular}

\section{BEST AVALABLE COPY}


Sampler $\# 2$ Sampier volume $315.3 \mathrm{cc}$ R6S-055.

Fill Gas Hydrogen(30.3\%) / Argon(24.9\%) / Nitrogen(39.8\%) / Ammonia(5.0\%)

Fill Pressure 750.2 Fill Temperature $22^{\circ} \mathrm{C}$

Fill Date 9-12.95 Fill Time 10.88

Sample Recovery (to test canister): Date 9-13-95 Time 9:57 Am

Sample Recovery Dump Pressure 177.1 Temperature $23^{\circ} \mathrm{C}$ Mass Spec. Analysis Date $9-13-95$ Approximate Analys is Time MS Ammonia Result: $1.3 \%$

MS Results: $\mathrm{H}_{2} 31 \%$, Ar $26.1 \%$, Nitrogen $41.6 \%$ Expected $\mathrm{H}_{2} 31.5 \%$, Ar $25.9 \%$, Nitrogen $41.4 \%$

- After compensation for ammonia wash out. $\Delta t=24 \mathrm{~h}$

Sampler 1 Sampler Volume 314.6 R6S-056

Fill Gas Hydrogen(30.3\%) / Argon(24.9\%) / Nitrogen(39.8\%) / Ammonia(5.0\%)

Fill Pressure 749.5 Fill Temperature $22^{\circ} \mathrm{C}$

Fill Date $9-12-95$ Fill Time 7:00 am

Sample Recovery (to test canister): Date $\frac{9+15.55}{13-955^{0}}$ Time 8.50 AM Sample Recovery Dump Pressure $177^{16}+\mathrm{rD}^{\circ}$ Temperature Mass Spec. Analysis Date $9 \cdot 15-95$ Approximate Analysis Time bepeman MS Ammonia Result: $1.3 \%$

MS Results: $\mathrm{H}_{2} 30.5 \%$, $\operatorname{Ar} 26.2 \%$, Nitrogen $41.9 \%$ Expected ${ }^{*} \mathrm{H}_{2} 31.5 \%$ Ar $25.9 \%$ Nitrogen $41.4 \%$

- After compensation for ammonia wash out. $\Delta t=74 \mathrm{~h}$ 
Sampler \#3 Sampler volume 315.1 ec RGS-057

Fill Gas Hydrogen(30.3\%) / Argon(24.9\%) / Nitrogen(39.8\%) / Ammonia(5.0\%)

Fill Pressure 750.0 Fill Temperature $23^{\circ} \mathrm{C}$

Fill Date $9-12-95$ Fill Time 103

Sample Recovery (to test canister): Date 9-20-95 Time 8:07 Am

Sample Recovery Dump Pressure 174.3 Temperature $22^{\circ} \mathrm{C}$

Mass Spec. Analysis Date 9-21-95 Approximate Analysis Time 9:00 Am

MS Ammonia Result: $0.04 \%$

MS Results: $\mathrm{H}_{2} 31.3 \%$, Ar $26.4 \%$, Nitrogen $42.2 \%$ Expected $\mathrm{H}_{2} 31.9 \%, \operatorname{Ar} 26.2 \%$, Nitrogen 41.9 \%

- After compensation for ammonia wash out. $\Delta t=187 \mathrm{~h}$

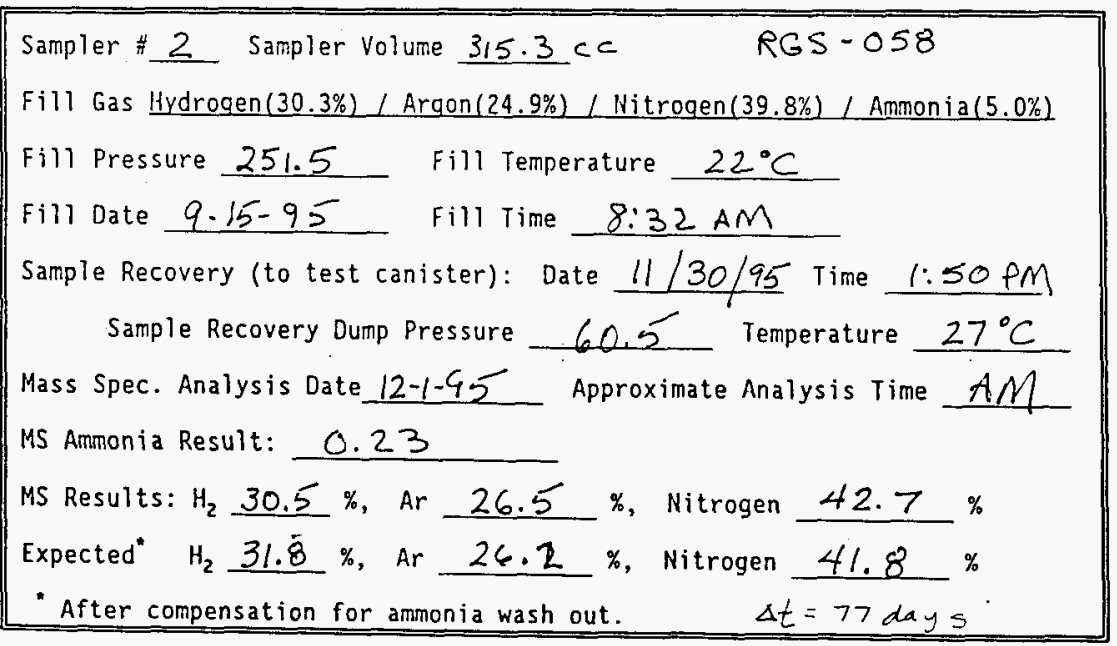




\section{APPENDIX D \\ Adjusting Gas Composition for Leakage or Ammonia Washout}

The result of a gas analysis may indicate the presence of potential air leakage or outgassing due to the presence of its constituents (oxygen, argon). Also, when MIX\#l gas was used, some ammonia "washout" was usually experienced with the MS analysis. These composition analyses can be compensated for this gain or loss of gas, as will be discussed.

\section{D.1 Leakage/Outgassing}

Since the RGSS has been carefully leak tested, actual leakage during a test normally would not exceed $1 \times 10^{-6} \mathrm{~atm} / \mathrm{cc} / \mathrm{sec}$ unless a defective sampler or poor attachment of a sampler to the RGSS occurs. Outgassing from the RGSS chamber walls will always occur, although the effect can be minimized by extended vacuum pumpdowns prior to performing a test. Compensation of composition analysis results for extra air can be made provided it is known that the tracking constituent (oxygen, argon) were not originally in the sample gas. It is assumed that the leaked or outgassed air has a normal composition; i.e., nitrogen at $78.084 \%$, oxygen at $20.946 \%$ and argon at $0.934 \%$.

\section{D.1.1 Oxygen Tracer}

Using oxygen as the tracer element for air, the adjusted $\left(A_{i}\right)$ fraction (of the ith gas component) of the original sample gas is given by

$$
A_{i}=\frac{Q_{i}-f_{i}}{\left(1-f_{a I}-f_{n i t}-f_{o z}\right)}
$$

where $Q_{i}$ is the fraction actually measured for the $i$ th gas component. If the $i$ th gas component is not nitrogen, oxygen or argon, then $f_{i}=0$. For nitrogen or argon, then $f_{\mathfrak{i}}$ equals the appropriate value of either

or

$$
f_{\text {nit }}=0.78084 / 0.20946 * f_{02} \text {, }
$$

$$
f_{\text {ar }}=0.00934 / 0.20946 * f_{02} \text {, }
$$

where

$$
f_{02}=\text { measured fraction of oxygen. }
$$

\section{D.1.2 Argon Tracer}

Using argon as the tracer element for air, the same equation applies as for oxygen, except that

$$
f_{\text {nit }}=0.78084 / 0.00934 * f_{a r} \text {, }
$$


and

$$
f_{02}=0.20946 / 0.00934 * f_{\text {ar }},
$$

where

$$
f_{a r}=\text { measured fraction of argon. }
$$

As an example, compensation for air outgassing during test RGS-001 was made in the following steps. The measured composition (see Table 12) was $Q_{\text {N2O }}=0.290, Q_{\text {nit }}=0.327, Q_{\text {he }}=0.371$. 0xygen (unexpected) was used as the tracer, so that $f_{02}=0.0104$. Thus, $f_{\text {nit }}=0.03877$ and $f_{a r}=4.6374 \times 10^{-4}$. Let $f_{\text {sum }}=f_{02}+f_{\text {nit }}+f_{\text {ar }}=0.04963$, then

$$
\begin{gathered}
A_{\mathrm{N} 20}=.290 /(1-0.04963)=0.290 / 0.950366=0.3051, \\
A_{\text {nit }}=(0.327-0.03877) /(0.950366)=0.3033,
\end{gathered}
$$

and

$$
A_{\text {he }}=0.371 / 0.950366=0.3904 \text {, }
$$

which are in excellent agreement with the control sample (RGS-002) results.

\section{D.2 Ammonia Washout}

It was difficult to transfer a gas mix containing ammonia from a collection vessel into the 325 Building mass spectrometer without losing some of the ammonia to wall surfaces and other moisture traps. Thus even the control samples taken directly from the vendor's gas bottle into a collection canister and to the MS resulted in low ammonia concentration results. Whenever gas MIX\#1 was used in a test with water simulant, all of the ammonia washed out of the gas into the water, as would be expected.

An algorithm to compensate the known composition of MIX\#l gas for ammonia washout, thus allowing a comparison with the MS gas analysis results was made as follows. The new fraction of a MIX\#l gas component $\left(A_{i}\right)$ remaining after ammonia washout is given by

$$
A C_{i}=C_{i} * Z
$$

where $Z=\left(1-N C_{\text {amm }}\right) / C_{\text {sum }}$, with $N C_{\text {amm }}$ being the measured fraction of ammonia from the MS data, and $C_{\text {sum }}=C_{H 2}+C_{\text {ar }}+C_{n i t}$ where $C_{i}$ is the known starting fraction of a given component of gas MIX\#1.

As an example, compensation of the MIX\#l composition is made for test RGS-005 step by step; RGS-004 control test values are used for the known composition of MIX\#1, rather than vendor values. The MS value for ammonia was $N C_{\text {amm }}=0.014$; the original measured fractions for the rest of MIX\#l components are $C_{\mathrm{H} 2}=0.292, C_{\text {ar }}=0.259$ and $C_{\text {nit }}=0.417$; thus, $C_{\text {sum }}=0.968$ when the ammonia concentration was measured as 2.9 percent. Then

$$
\begin{gathered}
A C_{H 2}=0.292 *(1-0.014) / .968=0.292 * 1.0186=0.2974, \\
A C_{a r}=0.259 * 1.0186=0.2638,
\end{gathered}
$$




$$
A C_{\text {nit }}=0.417 * 1.0186=0.4248,
$$

which are in good agreement with the actual test results (see Table 12). 


\section{APPENDIX E \\ ACCEPTANCE TEST SUMMARY}

\begin{tabular}{|c|c|c|c|}
\hline $\begin{array}{l}\text { Test } \\
\text { Name }\end{array}$ & Description of Test & Status & Comments \\
\hline RGS_001 & $\begin{array}{l}\text { Injection MIX2 }-26.7{ }^{\circ} \mathrm{C} \text { Dry } \\
\text { PNL IMS Anal. }(6-30-95 \text { Log-in No. } 95-06958)\end{array}$ & \multirow{3}{*}{$\begin{array}{l}\text { MIX2 Dry } \\
\text { Tests are } \\
\text { Completed }\end{array}$} & Excellent Results \\
\hline RGS_002 & $\begin{array}{l}\text { MIX2 Contro1 (001) - Ambient } \\
\text { PAL iMS Anal. }(6-30-95 \text { Log-in No. } 95-06959)\end{array}$ & & Taken with 001 \\
\hline RGS_003 & $\begin{array}{l}\text { Injection MIX2 }-52.7^{\circ} \mathrm{C} \text { Dry } \\
\text { PNL IMS Anal.(6-30-95 Log-in Ho. } 95-07005)\end{array}$ & & Excellent Results \\
\hline RGS_004 & $\begin{array}{l}\text { MIXI Control (005) - Ambient } \\
\text { PML IMS Anal. (7-12-95 Log-in No. 95-07111) }\end{array}$ & \multirow[t]{3}{*}{ NH3 Low. } & MS NH3 $2.9 \%$, Rest OK \\
\hline RGS_005 & $\begin{array}{l}\text { Injection MIXI }-28.0{ }^{\circ} \mathrm{C} \text { Dry } \\
\text { PNL IMS Anal.(7-12-95 Log-in No. } 95-07112)\end{array}$ & & $\begin{array}{l}\text { MS NH3 } 1.4 \% \text {, Rest OK } \\
\text { WC NH3 } 2.1 \%\end{array}$ \\
\hline RGS_006 & $\begin{array}{l}\text { Injection MIX1 }-52.4{ }^{\circ} \mathrm{C} \text { Dry } \\
\text { PNL IMS Anal.(7-12-95 Log-in No. } 95-07123)\end{array}$ & & $\begin{array}{l}\text { MS NH3 } 1.8 \% \text {, Rest OK } \\
\text { WC NH3 } 2.7 \%\end{array}$ \\
\hline RGS 007 & Sampler Air Test & Complete & Volume Verif. - OK \\
\hline RGS_008 & Ammonia (MIXI) $-25.4{ }^{\circ} \mathrm{C}$ Dry & \multirow{2}{*}{$\begin{array}{l}\text { NH3 Still } \\
\text { Low }\end{array}$} & WC NH3 $3.48 \%$ \\
\hline RGS_009 & Ammonia (MIXI) $-52.5^{\circ} \mathrm{C}$ Dry & & WC NH3 $2.74 \%$ \\
\hline RGS_010 & Air/Water $25.7^{\circ} \mathrm{C}-$ No 2nd $\mathrm{V}$. & \multirow{3}{*}{$\begin{array}{l}\text { Air/H20 \& } \\
\text { Sampler } \\
\text { Tests: } \\
\text { General } \\
\text { Problems }\end{array}$} & Sampler - Leak! \\
\hline RGS_011 & Air $(39.2 \mathrm{cc}) /$ Water $26.4{ }^{\circ} \mathrm{C}$ & & $\begin{array}{l}\text { Sampler - SPT, Hg OK; } \\
\text { BT High }\end{array}$ \\
\hline RGS_012 & Air $(39.9 \mathrm{cC}) /$ Water $52.1{ }^{\circ} \mathrm{C}$ & & $\begin{array}{l}\text { Sampler - SPT Too } \\
\text { High; Plugged filter } \\
\text { inval. BT, Hg }\end{array}$ \\
\hline RGS_013 & $\operatorname{Air}(39.9 \mathrm{cC}) /$ Water $21.8{ }^{\circ} \mathrm{C}$ & \multirow{2}{*}{$\begin{array}{l}\text { Gen. } \\
\text { Prob. } \\
\text { New Line } \\
\text { Volume }\end{array}$} & $\begin{array}{l}\text { Sampler - SPT high; } \\
\text { BT, Hg OK }\end{array}$ \\
\hline RGS_014 & Air $(40.2 \mathrm{cC}) /$ Water $53.4{ }^{\circ} \mathrm{C}$ & & $\begin{array}{l}\text { Sampler - SPT, BT } \\
\text { bad; Hg OK but filter } \\
\text { plugged }\end{array}$ \\
\hline RGS_015 & $\begin{array}{l}\text { Injected (N20+)/Water } 22.0^{\circ} \mathrm{C} \\
\text { PML IMS Anal.(7-31-95 Log-in No. } 95-07533)\end{array}$ & \multirow{3}{*}{$\begin{array}{l}\text { Inj. N20+ } \\
\text { Problems }\end{array}$} & $\begin{array}{l}\text { Obvious Leak! MS } \\
\text { comp. awfur }\end{array}$ \\
\hline RGS_016 & $\begin{array}{l}\text { Injected (N20+)/Water } 22.2^{\circ} \mathrm{C} \\
\text { PNL IMS Anal.(7-31-95 Log-in No. } 95-07534)\end{array}$ & & $\begin{array}{l}\mathrm{Hg} \& \mathrm{BT} \text { OK; SPT \& MS } \\
\text { comp. poor }\end{array}$ \\
\hline RGS_017 & $\begin{array}{l}\text { Injected(N20+)/Water } 53.3{ }^{\circ} \mathrm{C} \\
\text { PNL IMS Anal.(7-31-95 Log-in No. } 95-07545)\end{array}$ & & $\begin{array}{l}\text { Filter Plugged. MS } \\
\text { comp. awfu1 }\end{array}$ \\
\hline RGS_018 & Air $(19.7 \mathrm{cc}) /$ Carbopol $22{ }^{\circ} \mathrm{C}$ & $\begin{array}{l}\text { Carbopol } \\
\text { May Not } \\
\text { Work } \\
\text {-NSC- }\end{array}$ & $\begin{array}{l}\text { Sampler - Aborted- } \\
\text { Massive Leak }\end{array}$ \\
\hline
\end{tabular}


Page E-2

\begin{tabular}{|c|c|c|c|}
\hline $\begin{array}{l}\text { Test } \\
\text { Name }\end{array}$ & Description of Test & Status & Comments \\
\hline RGS_019 & $\operatorname{Air}(22.7 \mathrm{cc}) / \mathrm{Carbopol} 22{ }^{\circ} \mathrm{C}$ & No Good & $\begin{array}{l}\text { Sampler - Massive } \\
\text { Outgassing/Leak?? }\end{array}$ \\
\hline RGS 020 & Ammonia (MIX1) $-21.9^{\circ} \mathrm{C}$ Dry & NH3 Low & WC NH3 $2.0 \%$ \\
\hline RGS_021 & $\begin{array}{l}\text { Injected }(\mathrm{N} 2 \mathrm{O}+) / \text { Water } 022^{\circ} \mathrm{C} \\
\text { Note: Water not degassed. } \\
\text { PNL IMS Anal. }(8-15-95 \text { Log-in No. } 95-07848) \\
\text { PNL IMS Anal. }(8-16-95 \mathrm{Log} \text { - in No. } 95-07849)\end{array}$ & Not Good & $\begin{array}{l}\text { Pumped and unpumped - } \\
\text { not good enough }\end{array}$ \\
\hline RGS 022 & $\begin{array}{l}\text { Dry gas injection } / 22^{\circ} \mathrm{C}(\mathrm{N} 2 \mathrm{O}+) \\
\text { PNL IMS Anal.(8-16-95 Log-in No. 95-07857) }\end{array}$ & $\begin{array}{l}\text { Sti11 } \\
\text { works! }\end{array}$ & Excellent MS results \\
\hline RGS 023 & Injected $(\mathrm{N} 20+) /$ Water $022^{\circ} \mathrm{C}$ & Not Good & LEAKED! Aborted. \\
\hline RGS_024 & $\begin{array}{l}\text { Injected(N20+)/Water } 022^{\circ} \mathrm{C} \\
\text { (New, degassed water) }\end{array}$ & \multirow{3}{*}{$\begin{array}{l}\text { Degassed } \\
\text { Water } \\
\text { Injection } \\
\text { Tests } \\
\text { Works!!!! }\end{array}$} & $\begin{array}{l}\text { ABORTED! 2nd Vol. not } \\
\text { pumped down. }\end{array}$ \\
\hline RGS_025 & $\begin{array}{l}\text { Injected }(\mathrm{N} 20+) / \text { Water o } 22^{\circ} \mathrm{C} \\
\text { (Reused water) } \\
\text { PNL IMS Anal.(8-18-95 Log-in No. } 95-07888)\end{array}$ & & Good MS results \\
\hline RGS_026 & $\begin{array}{l}\text { Injected (N2O+)/Water o } 22^{\circ} \mathrm{C} \\
752.2 \text { Torr (Reused Water) } \\
\text { PNL IMS Anal.(8-18-95 Log-in No. } 95-07894)\end{array}$ & & Excellent MS results \\
\hline RGS_027 & $\begin{array}{l}\text { RCK Inj. (N2O+)/H2O \& } 22^{\circ} \mathrm{C} \\
400 \text {. } 1 \text { Torr (Reused Water) } \\
\text { PNL ims anal.(8-22-95 Log-in No. } 95-08090)\end{array}$ & \multirow{3}{*}{$\begin{array}{l}\text { RCK } \\
\text { Injection } \\
\text { Tests }\end{array}$} & Exce1lent MS results \\
\hline RGS 028 & $\begin{array}{l}\text { RCK Inj. }(\mathrm{N} 2 \mathrm{O}+) / \mathrm{H} 2 \mathrm{O} \text { ( } 22^{\circ} \mathrm{C} \\
200.1 \text { Torr (Reused Water) } \\
\text { PNL IMS Anal.(8-22-95 Log-in No. } 95-08091)\end{array}$ & & Excellent MS results \\
\hline RGS_029 & $\begin{array}{l}\text { RCK Inj. (N2O+) } / \mathrm{H} 20 \text { o } 22^{\circ} \mathrm{C} \\
50.1 \text { Torr (Reused Water) } \\
\text { PNL IMS Anal.(8-23-95 Log-in No. } 95-08094 \text { ) }\end{array}$ & & Poor MS results \\
\hline RGS_030 & $\begin{array}{l}\text { BH Inj. (Argon) } / \mathrm{H} 20 \text { o } 22^{\circ} \mathrm{C} \text { : } \\
741.1 \text { Torr (Reused Water) } \\
\text { PNL iMS Anal.(8-23-95 Log-in No. } 95-08037 \text { ) }\end{array}$ & \multirow{6}{*}{$\begin{array}{l}\text { Argon } \\
\text { Only } \\
\text { is } \\
\text { Simpler } \\
\text { Within } \\
\text { Specs. } \\
\text { B. Hey } \\
\text { Ar/H2O } \\
\text { Injection } \\
\text { Tests }\end{array}$} & $\begin{array}{l}\text { 4.5\% MS Error } \\
\text { (Unpumped) }\end{array}$ \\
\hline RGS_031 & $\begin{array}{l}\text { BH Inj. (Argon) } / \mathrm{H} 20 \text { o } 22^{\circ} \mathrm{C} \text { : } \\
\text { Same test as RGS 030 (pumped) } \\
\text { PNL IHS Anal.(B-23-95 Log-in No. } 95-08038 \text { ) }\end{array}$ & & $\begin{array}{l}\text { 4.5\% MS Error } \\
\text { (Hg Pumped) }\end{array}$ \\
\hline RGS_032 & $\begin{array}{l}\text { BH Control Sample (Argon) } \\
\text { PNL IMS Anal.(8-24-95 Log-in No. 95-08039) }\end{array}$ & & $99.95 \%$ Ar (MS reșult) \\
\hline RGS_033 & $\begin{array}{l}\text { BH Inj. Argon ( } 740.4 T \text { ) } / \mathrm{H} 20 \text { (New } \\
\text { Water, degassed) } \\
\text { PNL IMS Anal. (8-24-95 Log-in No. 95-08048) }\end{array}$ & & $1.6 \%$ MS Error \\
\hline RGS_034 & $\begin{array}{l}\text { BH Inj. } 400 \text { Torr Argon/Water } \\
\text { (Reused water) } \\
\text { PNL IMS Anal. (8-25-95 Log-in No. } 95-08057 \text { ) }\end{array}$ & & 98.3\% Ar (Unpumped) \\
\hline RGS_035 & $\begin{array}{l}\text { Same test as RGS } 034 \text { (pumped) } \\
\text { PNL IMS Anal.(8-25-95 [og-in No. } 95-08058)\end{array}$ & & $99.7 \%$ Ar (Hg Pumped) \\
\hline
\end{tabular}




\begin{tabular}{|c|c|c|c|}
\hline $\begin{array}{l}\text { Test } \\
\text { Name }\end{array}$ & Description of Test & Status & Comments \\
\hline RGS_036 & $\begin{array}{l}\text { BH Inj. 400.9T Ar/Water-Reused } \\
\text { PNL IHS Anal. (8-25-95 Log-in No. } 95-08059)\end{array}$ & B. Hey & $99.6 \% \mathrm{Ar}$ (Hg Pumped) \\
\hline RGS_037 & $\begin{array}{l}\text { Injected }\left(\mathrm{H}_{2}+\right) \text { @ } 740.1 \mathrm{~T} / \text { Water } \\
\text { (Reused Water) } \\
\text { PNL IMS Anal.(8-25-95 Log-in No. 95-08070) }\end{array}$ & $\mathrm{H}_{2}$ !!!!!!! & Good MS Results \\
\hline RGS_038 & $\begin{array}{l}\text { Inj. Ar }(50.7 T) / \text { Water-Reused } \\
\text { PNL ims Anal.(8-28-95 Log-in No. 95-08239) }\end{array}$ & Ar Tests & $82.8 \% \mathrm{Ar}$ \\
\hline RGS_039 & $\begin{array}{l}\text { Inj. Ar (102.0T)/Water-Reused } \\
\text { PNL IMS Anal.(8-28-95 Log-in No. 95-08239) }\end{array}$ & Ar & $96.3 \% \mathrm{Ar}$ \\
\hline RGS_040 & $\begin{array}{l}\text { BH Inj. Ar(201.0T)/Water- } \\
\text { Reused. "Dumped" Sample } \\
\text { PNL IMS Anat.(8-29-95 Log-in No. 95-08258) }\end{array}$ & \multirow{5}{*}{$\begin{array}{l}\text { B Hey } \\
\text { Ar } / \mathrm{H}_{2} \mathrm{O} \\
\text { Injection } \\
\text { Tests }\end{array}$} & $\begin{array}{l}\text { ERROR - No Ar } \\
\text { originally obtained } \\
\text { in injection can. }\end{array}$ \\
\hline RGS_041 & $\begin{array}{l}\text { BH - Same as RGS_040, but Hg } \\
\text { Pumped. } \\
\text { PNL IMS Anal.(8-29-95 Log-in No. } 95-08259)\end{array}$ & & $\begin{array}{l}\text { ERROR - No Ar } \\
\text { originally obtained } \\
\text { in injection can. }\end{array}$ \\
\hline RGS_042 & $\begin{array}{l}\text { BH Inj. 200.0T Ar/Water - was } \\
\text { Hg pumped. Reused Water } \\
\text { PNL IMS Anal.(8-29-95 Log-in No. 95-08260) }\end{array}$ & & $\begin{array}{l}\text { ERROR - No Ar } \\
\text { originally obtained } \\
\text { in injection can. }\end{array}$ \\
\hline $\operatorname{RGS}_{\bar{B}} 043$ & $\begin{array}{l}\text { BH Inj. } 100.1 \mathrm{~T} \text { Ar/Water - Hg } \\
\text { pumped. Reused Water } \\
\text { PNL IMS Anal.(B-29-95 Log-in No. 95-08267) }\end{array}$ & & $94.4 \%$ Ar MS Result \\
\hline $\operatorname{RGS}_{\bar{C}} 043$ & $\begin{array}{l}\text { BH Inj. 100.1T Ar/Water - } \\
\text { "Dumped". Reused Water } \\
\text { PNL IMS Anal. (8-29-95 Log-in No. 95-08268) }\end{array}$ & & $94.5 \%$ Ar MS Result \\
\hline RGS_044 & $\begin{array}{l}\text { Argon Control Sample } \\
\text { PNL IMS Anal.(8-29-95 Log-in No. 95-08269) }\end{array}$ & & $99.949 \%$ Ar MS Result \\
\hline $\operatorname{RGS}_{\bar{A}} 045$ & $\begin{array}{l}\text { BH Inj. Ar(100.0T)/H20-Reused } \\
\text { "Dumped" } \\
\text { PNL IMS Anal.(8-30-95 Log-in No. } 95-08285)\end{array}$ & \multirow{4}{*}{$\begin{array}{l}\text { B Hey } \\
\text { Ar } / \text { H2O } \\
\text { Injection } \\
\text { Tests }\end{array}$} & 85.9\% Ar MS Result \\
\hline $\operatorname{RGS}_{\bar{B}} 045$ & $\begin{array}{l}\text { BH Inj. Ar(100.0T)/H20-Reused } \\
\text { "Hg Pumped" } \\
\text { PNL IMS Anal.(8-30-95 Log-in No. 95-08286) }\end{array}$ & & 97\% Ar MS Result \\
\hline $\operatorname{RGS}_{\bar{A}} 046$ & $\begin{array}{l}\text { BH Inj. Ar(75.0T)/H20-Reused } \\
\text { "Dumped" } \\
\text { PNL IMS Anal. (8-30-95 Log-in No. 95-08287) }\end{array}$ & & $31.2 \%$ Ar MS Result \\
\hline $\operatorname{RGS}_{\bar{B}} 046$ & $\begin{array}{l}\text { BH Inj. Ar(75.0T)/H20-Reused } \\
\text { "Hg Pumped" } \\
\text { PNL IMS Anal.(8-30-95 Log-in No. 95-08288) }\end{array}$ & & $95.65 \%$ Ar MS Result \\
\hline RGS_047 & $\begin{array}{l}\text { Inj. Ar }(400.6 \mathrm{~T}) / \text { Water-Reused } \\
\text { Hot Cycle to } 50.6^{\circ} \mathrm{C} \\
\text { PNL IMS Anal. }(8-30-95 \text { Log-in No. } 95-08377)\end{array}$ & \multirow{2}{*}{$\begin{array}{l}\text { Injected } \\
\text { Ar/H2O- } \\
\text { Degassed } \\
\text { Tests }\end{array}$} & $\begin{array}{l}99.25 \% \text { Ar MS Result } \\
\text { Hg Pumped }\end{array}$ \\
\hline $\operatorname{RGS}_{\bar{A}} 048$ & $\begin{array}{l}\text { Inj. Ar }(200.1 T) / \text { Water-Reused } \\
\text { "Dumped" } \\
\text { PNL IMS Anal.(8-31-95 Log-in No. 95-08382) }\end{array}$ & & $\begin{array}{l}92.5 \% \text { Ar MS Result } \\
\text { Dumped Sample }\end{array}$ \\
\hline
\end{tabular}




\begin{tabular}{|c|c|c|c|}
\hline $\begin{array}{l}\text { Test } \\
\text { Name }\end{array}$ & Description of Test & Status & Comments \\
\hline $\operatorname{RGS}_{\bar{B}} 048$ & $\begin{array}{l}\text { Inj. Ar }(200.1 \mathrm{~T}) / \text { Water-Reused } \\
\text { "Hg Pumped" } \\
\text { PNL IMS Anal.(8-31-95 Log-in No. 95-08383) }\end{array}$ & \multirow{3}{*}{$\begin{array}{l}\text { Injected } \\
\text { Ar/H20- } \\
\text { Degassed } \\
\text { Tests }\end{array}$} & $\begin{array}{l}93.7 \% \text { Ar MS Result } \\
\text { Hg Pumped Sample }\end{array}$ \\
\hline RGS_049 & $\begin{array}{l}\text { Inj. Ar }(201.7) / \text { Water-Reused } \\
\text { Hot Cycle to } 50.1^{\circ} \mathrm{C} \\
\text { PNL IMS Anal. (8-31-95 Log-in No. } 95-08415)\end{array}$ & & $\begin{array}{l}98.59 \% \text { Ar MS Result } \\
\text { Hg Pumped Sample }\end{array}$ \\
\hline RGS_050 & $\begin{array}{l}\text { Inj. Ar }(100.2) / \text { Water-Reused } \\
\text { Hot Cycle to } 50.1^{\circ} \mathrm{C} \\
\text { PNL IMS Anal.(9-1-95 Log-in No. } 95-08424)\end{array}$ & & $\begin{array}{l}\text { 97.38 Ar MS Result } \\
\text { Hg Pumped Sample }\end{array}$ \\
\hline RGS_051 & $\begin{array}{l}\text { Complete Sampler Argon/Water } \\
\text { RGSS Test: Ambient Temp. only } \\
\text { PHL IMS Anal. (9-5-95 Log-in No. } 95-08493 \text { ) }\end{array}$ & \multirow{3}{*}{$\begin{array}{l}\text { Complete } \\
\text { RGSS } \\
\text { Gas/Water } \\
\text { Sampler } \\
\text { Tests } \\
\text { GOOD }\end{array}$} & $\begin{array}{l}98.0 \% \text { Ar MS Results } \\
\text { Overnight degas. }\end{array}$ \\
\hline RGS_052 & $\begin{array}{l}\text { Complete Sampler Argon/Water } \\
\text { RGSS Test: Hot Cycle to } \\
50.5{ }^{\circ} \mathrm{C} \\
\text { PNL IMS Anal.(9-6-95 Log-in No. } 95-08507)\end{array}$ & & $\begin{array}{l}91.3 \% \text { Ar MS Results } \\
\text { Only } 5 \text { hr degas. }\end{array}$ \\
\hline RGS_053 & $\begin{array}{l}\text { Complete Sampler HELIUM/Water } \\
\text { RGSS Test: Hot Cycle to } \\
51.3{ }^{\circ} \mathrm{C} \\
\text { PNL IMS Anal.(9-8-95 Log-in No. } 95-08523)\end{array}$ & & $\begin{array}{l}96.89 \% \text { He MS Results } \\
\text { Overnight Degas - } \\
\text { (Sampler \& RGSS) }\end{array}$ \\
\hline RGS_054 & $\begin{array}{l}\text { Hel ium Control Sample } \\
\text { PNL IMS Anal. (9-19-95 Log-in No. 95-08554) }\end{array}$ & & $99.78 \%$ He MS Results \\
\hline RGS-55 & $\begin{array}{l}\mathrm{H}_{2} \text { Sampler Leak Test }(24 \mathrm{hr}) \\
\text { PNL IMS Anal.(9-13-95 Log-in No. } 95-08647)\end{array}$ & \multirow{4}{*}{$\begin{array}{l}\text { MIX\#1 } \mathrm{H}_{2}+ \\
\text { Sampler } \\
\text { "Aging" } \\
\text { Tests }\end{array}$} & Maximum Error $0.5 \%$ \\
\hline RGS-56 & $\begin{array}{l}\mathrm{H}_{2} \text { Sampler Leak Test }(74 \mathrm{hr}) \\
\text { PNL IMS Anal.(9-15-95 Log-in No. } 95-08719)\end{array}$ & & Maximum Error $1.0 \%$ \\
\hline RGS-57 & $\begin{array}{l}\mathrm{H}_{2} \text { Sampler Leak Test }(187 \mathrm{hr}) \\
\text { PNL IMS Anal. }(9-21-95 \text { Log-in No. 95-08778) }\end{array}$ & & Maximum Error $0.6 \%$ \\
\hline RGS-58 & $\begin{array}{l}\mathrm{H}_{2} \text { Sampler Leak Test }(1829 \mathrm{hr}) \\
\text { PNL IMS Anal.(11-30-95 Log-in No.96-01643) } \\
\end{array}$ & & Maximum Error $0.4 \%$ \\
\hline
\end{tabular}




\section{APPENDIX F \\ Letter Report: Hydrogen Permeation Rate}

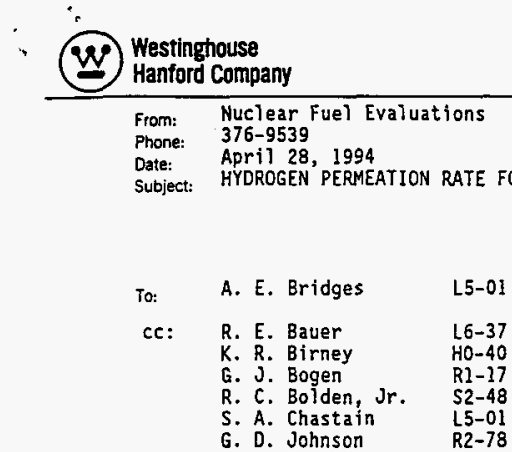

An evaluation was performed to estimate the hydrogen permeation rate for the Retained Gas Sampler. The evaluations were done in a conservative fashion and should represent an upper bound for hydrogen permeation. Calculations were performed for two temperatures: a nominal value of $100^{\circ} \mathrm{F}$, and the upper design limit of $200^{\circ} \mathrm{F}$. At $100^{\circ} \mathrm{F}$ the total permeation rate is calculated to be $<0.1 \%$ of the hydrogen inventory per day, while at $200^{\circ} \mathrm{F}$ the calculated rate is $0.4 \%$ per day.

Individual calculations were performed for the sampler housing, the 0 -ring seal on the piston, and the viton seal for the rotary valve. Conservative approaches were applied throughout to obtain upper bound estimates. For example, the retrieved sample was assumed to be $100 \%$ hydrogen to provide the maximum partial pressure for permeation, and permeability values selected for the various materials were the highest reported. In realjty, most of the hydrogen in the recovered samples would be expected to remain entrained in the viscous waste material and not have direct access to the containment barriers.

Most of the hydrogen permeation was calculated to occur through the 0 -ring seal on the piston, which accounted for about $2 / 3$ of the total hydrogen permeation rate. Accordingly, application of multipie 0-ring seals in this region could substantially reduce the calculated permeation rate.

Details of the hydrogen permeation calculations for the Retained Gas Sampler are presented in the following pages.

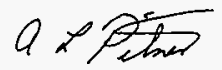

A. L. Pitner

1 
Hydrogen Sample Inventory

As a bounding case, assume that the sample obtained in the 19-inch piston stroke volume is $100 \%$ hydrogen at $150^{\circ} \mathrm{F}$ under a hydrostatic head of 3 atmospheres (Wootan 1993).

$$
\begin{aligned}
n & =\frac{P V}{R T} \\
\text { where } n & =\text { moles } \\
P & =\text { pressure }=3 \text { atm } \\
V & =\text { volume }=\frac{\pi}{4} d^{2} \ell=(0.7854)(1.126 \mathrm{in.})^{2}(19 \mathrm{in.}) \\
R & =\text { gas constant }=0.082051 \cdot \mathrm{atm} / \mathrm{mol} \cdot \mathrm{K} \\
T & =\text { temperature }=150{ }^{\circ} \mathrm{F}=339 \mathrm{~K} \\
n & =\frac{18.92 \mathrm{in}^{3}=0.310 \mathrm{liter}}{(0.08205 \mathrm{ltm})(0.3101)}
\end{aligned}
$$




\section{Permeation Through Sample Housing}

The permeation rate of hydrogen through metal is given by (Steward 1983)

$$
\begin{aligned}
Q / t & =K \frac{A}{\Delta x} \Delta P^{1 / 2} \\
\text { where } Q / t & =\text { mass permeation rate }(m o l / s) \\
K & =\text { permeability }\left(\mathrm{mol}^{\prime} / \mathrm{m} \cdot \mathrm{s} \cdot \mathrm{Pa}^{1 / 2}\right) \\
A & =\text { surface area }\left(\mathrm{m}^{2}\right) \\
\Delta \mathrm{X} & =\text { wall thickness }(\mathrm{m}) \\
\Delta \mathrm{P} & =\text { differential hydrogen partial pressure }(\mathrm{Pa})
\end{aligned}
$$

From (Steward 1983) for 304 stainless stee],

$\mathrm{K} 0100^{\circ} \mathrm{F}=10.4 \times 10^{-7} \exp (-7770 / 311)=1.84 \times 10^{-17} \mathrm{~mol} / \mathrm{m} \cdot \mathrm{s} \cdot \mathrm{Pa}^{1 / 2}$

$\mathrm{K} 200^{\circ} \mathrm{F}=10.4 \times 10^{-7} \exp (-7770 / 367)=8.04 \times 10^{-16} \mathrm{~mol} / \mathrm{m} \cdot \mathrm{s} \cdot \mathrm{Pa}^{1 / 2}$

$P$ a $100^{\circ} \mathrm{F}=3 \mathrm{~atm}(311 \mathrm{~K} / 339 \mathrm{~K})=2.53 \mathrm{~atm}=278,868 \mathrm{~Pa}$

$\mathrm{Pat} 200^{\circ} \mathrm{F}=3 \mathrm{~atm}(367 \mathrm{~K} / 339 \mathrm{~K})=3.25 \mathrm{~atm}=329,082 \mathrm{~Pa}$

$A=\pi(1.126)(19)=67.21 \mathrm{in}^{2}=0.0434 \mathrm{~m}^{2}$

$\Delta x=0.187$ in. $=0.00475 \mathrm{~m}$

$$
\begin{aligned}
Q / \mathrm{t} 0100^{\circ} \mathrm{F} & =\left(1.84 \times 10^{-17} \mathrm{~mol} / \mathrm{m} \cdot \mathrm{s} \cdot \mathrm{Pa}^{1 / 2}\right)\left(\frac{0.0434 \mathrm{~m}^{2}}{0.00475 \mathrm{~m}}\right)(278,868 \mathrm{~Pa})^{1 / 2} \\
& =8.88 \times 10^{-14} \mathrm{~mol} / \mathrm{s}=7.67 \times 10^{-9} \mathrm{~mol} / \text { day } \\
& =2.3 \times 10^{-5} \% / \text { day }
\end{aligned}
$$

$$
\begin{aligned}
Q / t=200^{\circ} \mathrm{F} & =\left(8.04 \times 10^{-16} \mathrm{~mol} / \mathrm{m} \cdot \mathrm{s} \cdot \mathrm{Pa}^{1 / 2}\right)\left(\frac{0.0434 \mathrm{~m}^{2}}{0.00475 \mathrm{~m}}\right)(329,082 \mathrm{~Pa})^{1 / 2} \\
& =4.21 \times 10^{-12} \mathrm{~mol} / \mathrm{s}=3.64 \times 10^{-7} \mathrm{~mol} / \text { day } \\
& =0.001 \% / \text { day }
\end{aligned}
$$




\section{Permeation Through 0-Ring}

The permeation through elastomers is related directiy to the hydrogen partial pressure rather than the square root of the hydrogen partial pressure (Irwin 1992)

$$
\begin{aligned}
Q / t & =K \frac{A}{\Delta x} \Delta P \\
\text { where } Q / t & =\text { mass permeation rate }(m o l / s) \\
K & =\text { permeability }(m o l / m \cdot s \cdot P a) \\
A & =\text { surface area }\left(m^{2}\right) \\
\Delta x & =\text { wall thickness }(m) \\
\Delta P & =\text { differential hydrogen partial pressure }(P a)
\end{aligned}
$$

The 0-ring material is a fluorocarbon (Viton). From (Irwin 1992), the permeability for viton as a function of temperature $\left(T={ }^{\circ} \mathrm{C}\right)$ is given by

$$
\begin{aligned}
& \mathrm{K}(\mathrm{mol} / \mathrm{m} \cdot \mathrm{s} \cdot \mathrm{Pa})=-2.51 \times 10^{-15}+2.96 \times 10^{-16} \mathrm{~T}-8.21 \times 10^{-18} \mathrm{~T}^{2} \\
& +1.338 \times 10^{-19} \mathrm{~T}^{3}-4.635 \times 10^{-22} \mathrm{~T}^{4} \\
& \text { For } 100^{\circ} \mathrm{F}\left(38^{\circ} \mathrm{C}\right), \quad \mathrm{K}=3.26 \times 10^{-15} \mathrm{~mol} / \mathrm{m} \cdot \mathrm{s} \cdot \mathrm{Pa} \\
& \text { For } 200^{\circ} \mathrm{F}\left(93{ }^{\circ} \mathrm{C}\right), \quad \mathrm{K}=2.73 \times 10^{-14} \mathrm{~mol} / \mathrm{m} \cdot \mathrm{s} \cdot \mathrm{Pa} \\
& \mathrm{P} 100^{\circ} \mathrm{F}=278,868 \mathrm{~Pa} \\
& P 200^{\circ} \mathrm{F}=329,082 \mathrm{~Pa}
\end{aligned}
$$

Area based on region between housing inner wall and bottom of 0-ring groove (Drawing H-2-85097, Rev 2, Sheet 4)

$$
A=\pi / 4\left(1.126^{2}-0.885^{2}\right)=0.381 \mathrm{in}^{2}=2.456 \times 10^{-4} \mathrm{~m}^{2}
$$

Determine the average lateral thickness in the circular cross section of an 0-ring. The resuits are conservative, because compression of the 0 -ring will deform it into a geometry that increases the effective thickness to resist gas permeation. 
The formulation for hydrogen permeation through the Viton seal in the rotary valve is the same as that for the $0-r i n g$ given above.

$$
\begin{aligned}
& \mathrm{K} 0100^{\circ} \mathrm{F}=3.26 \times 10^{-15} \mathrm{~mol} / \mathrm{m} \cdot \mathrm{s} \cdot \mathrm{Pa} \\
& K @ 200^{\circ} \mathrm{F}=2.73 \times 10^{-14} \mathrm{~mol} / \mathrm{m} \cdot \mathrm{s} \cdot \mathrm{Pa} \\
& \mathrm{P} O 100^{\circ} \mathrm{F}=278,868 \mathrm{~Pa} \\
& \mathrm{P} O 200^{\circ} \mathrm{F}=329,082 \mathrm{~Pa}
\end{aligned}
$$

Determine the inner exposure area of the Viton seal on the rotary valve. From Drawing H-2-85097, Rev 2, Sheet 5:

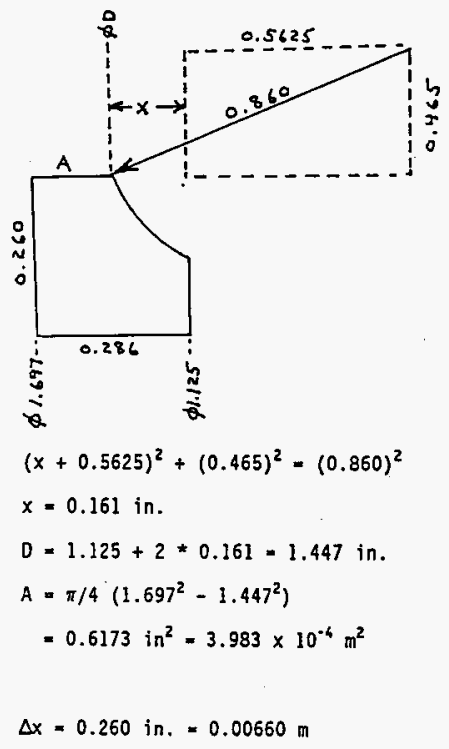




$$
\begin{aligned}
\text { Q/t } 0100{ }^{\circ} \mathrm{F} & =\left(3.26 \times 10^{-15} \mathrm{~mol} / \mathrm{m} \cdot \mathrm{s} \cdot \mathrm{Pa}\right)\left(\frac{3.983 \times 10^{-4} \mathrm{~m}^{2}}{0.00650 \mathrm{~m}}\right)(278,868 \mathrm{~Pa}) \\
& =5.49 \times 10^{-11} \mathrm{~mol} / \mathrm{s}=4.74 \times 10^{-6} \mathrm{~mol} / \mathrm{day} \\
& =0.014 \times / \mathrm{day} \\
Q / t \in 200{ }^{\circ} \mathrm{F} & =\left(2.73 \times 10^{-14} \mathrm{~mol} / \mathrm{m} \cdot \mathrm{s} \cdot \mathrm{Pa}\right)\left(\frac{3.983 \times 10^{-4} \mathrm{~m}^{2}}{0.00660 \mathrm{~m}}\right)(329,082 \mathrm{~Pa}) \\
& =5.42 \times 10^{-10} \mathrm{~mol} / \mathrm{s}=4.68 \times 10^{-5} \mathrm{~mol} / \mathrm{day} \\
& =0.140 \% / \mathrm{day}
\end{aligned}
$$

\section{Total Permeation Rate}

The total permeation rate of hydrogen through the universal sampier. containment is the sur of the above constituents.

$$
\begin{aligned}
& 0 / t=100^{\circ} \mathrm{F}=0.044 \% / \mathrm{day} \\
& 0 / t=200^{\circ} \mathrm{F}=0.433 \% / \mathrm{day}
\end{aligned}
$$

\section{References}

Irwin, J. J., 1992, "A Survey of Fluid Flow Leakage," WHC-SD-TP-RPT-003, Rev. 1, Westinghouse Hanford Company, Richland, Washington.

Steward, S. A., 1983, "Review of Hydrogen Isotope Permeability Through Materiais," UCRL-53441, Lawrence Livermore National Laboratory,

Livermore, California.

Wootan, D. W., and Bridges, A. E., 1993, "Preliminary Design Requirements and Criteria for the Prototype Retained Gas Sampler and Extraction (RGS) System," WHC-SD-WM-CR-054, Rev. 0, Westinghouse Hanford Company, Richland, Washington. 


\section{APPENDIX G \\ Two Volume Method Ammonia Vapor Pressure Approximation}

The Two Volume method for determining gas quantity and soluble gas vapor pressure $\left(P_{v}\right)$ relies on the approximation that $P_{v}$ remains relatively constant during the expansion of the extractor volume to include the 2nd Volume. Without this assumption, there are too many unknowns to produce Equations 5 and 6. Opening the valve to combine the extractor volume with the 2nd Volume results in only a 25 percent increase in the total volume to which the sample is exposed; thus superficially, the approximation that $P_{v}$ is constant seems reasonable when dealing with soluble gases.

However, Shekarriz and Norton (PNLFGP: 091595) have analyzed the approximation of constant ammonia vapor pressure using Henry's Law considerations, and point out some potential problems. Consequently, a further analysis will be performed here specific to the current RGSS geometry and Two Volume method.

\section{G.1 Ammonia Vapor Pressure Variation on Volume Expansion}

Two equations from Shekarriz and Norton are borrowed (A.2 and A.4) to start the analysis development:

$$
P_{v_{N t_{3}}}=H \frac{n_{1_{N H_{3}}}}{m_{L}}
$$

which is Henry's Law, where $H$ is Henry's constant for ammonia. The total mass of water in the waste is $m_{L}$, and $n_{I_{N H 3}}$ is the number of moles of ammonia in the liquid. The second equation was derived by Shekarriz and Norton as

$$
\frac{n_{I_{N H_{3}}}}{n_{N H_{3}}}=\frac{\left(R T / V_{g}\right)}{H / m_{L}+\left(R T / V_{g}\right)}
$$

where $n_{\mathrm{NH} 3}$ is the total number of moles of ammonia both in solution and in vapor. The volume available to the ammonia gas is $V_{g}$.

Dropping the $\mathrm{NH}_{3}$ subscripts, and combining the ratios of Equations $\mathrm{G}-1$ and $6-2$ resulting from two different volume states, then

$$
\frac{P_{v 1}}{P_{v 2}}=\frac{V_{g 2}+R T\left(m_{L} / H\right)}{V_{g 1}+R T\left(m_{L} / H\right)}
$$


where at temperature $T, P_{v 1}$ is the ammonia vapor pressure in volume $V_{g 1}$ and $P_{v 2}$ is the ammonia vapor pressure in the new volume $\mathrm{V}_{\mathrm{g2}}$.

When $H$ is very small (corresponding to high solubility), then Equation G-3 predicts that $P_{V 1} / P_{v 2} \approx 1$ and the approximation of constant vapor pressure is valid; when $H$ is very large (insoluble condition) then $P_{v 1} / P_{v 2} \approx V_{g 2} / V_{g 1}$ as would be predicted by the perfect gas law for insoluble gases.

For acceptance testing, the extractor volume plus feed line volume totals were $1350 \mathrm{~mL}+200 \mathrm{~mL}=1550 \mathrm{~mL}$. The 2nd Volume was approximately $320 \mathrm{~mL}$. Thus, in the case of an essentially full sampler, $V_{g 1}=1550 \mathrm{~mL}$ $315 \mathrm{~mL}=1235 \mathrm{~mL}$ and $V_{\mathrm{g} 2}=1235 \mathrm{~mL}+320 \mathrm{~mL}=1555 \mathrm{~mL}$. The worst case change in ammonia vapor pressure would then be $P_{v 1} / P_{v 2}=1.259$, or about 26 percent. For a nearly empty sampler, this worst case error would be reduced to about 20.6 percent.

By way of example, Shekarriz and Norton used $\mathrm{H} / \mathrm{m}_{\mathrm{L}}=2.2 \times 10^{6} \mathrm{~Pa} / \mathrm{mole}$ as an approximation for real waste. With RT $=2685.6 \mathrm{~J} / \mathrm{mole}$ (corresponding to $\left.50{ }^{\circ} \mathrm{C}\right)$, then Equation $\mathrm{G}-3$ becomes

$$
\frac{P_{\mathrm{v} 1}}{P_{\mathrm{v} 2}}=\frac{V_{g 2}+1220.7 \mathrm{~mL}}{V_{g 1}+1220.7 \mathrm{~mL}}
$$

Thus for a test starting with a full sampler, $P_{v 1} / P_{v 2}=1.13$ for a 13 percent reduction in ammonia vapor pressure when the evacuated 2nd Volume is exposed to the extractor. For a nearly empty sampler, this pressure ratio is 1.115 for an 11.5 percent vapor pressure change.

Figure G-1 indicates the sensitivity of the pressure ratio $P_{v 1} / P_{v 2}$ (to the actual value of $\left.\mathrm{H} / \mathrm{m}_{\mathrm{L}}\right)$ by plotting this ratio versus $X=\log _{10}\left(\mathrm{H} / \mathrm{m}_{\mathrm{L}} / 2.2 \times\right.$ $10^{6} \mathrm{~Pa} / \mathrm{mole}$ ).

\section{G.2 Ammonia Vapor Pressure Variation Effects on Two Volume Method Results}

A 26 percent change (for example) in ammonia pressure during expansion to include the 2nd Volume does not translate directly into a 26 percent error in gas quantity and vapor pressure calculated using the TV method, and in fact the error can be considerably less, as will be shown.

The basic equations used to derive Equations 5 and 6 for the TV method are reproduced here from the proof test report (WHC-SD-WM-TRP-232): 


$$
P_{E X L}=\frac{n_{g} R T}{V_{E X L}-V_{S L}}+P_{V}
$$

and

$$
P_{2}=\frac{n_{g} R T}{V_{E X I}-V_{S L}+V_{2}}+P_{V}
$$

The $V_{S L}$ determination is not affected by the ammonia vapor pressure change provided that the BT "charge" volume $\left(V_{2}+V_{L}\right)$ has been exposed to the waste sample in the extractor before it is valved out and charged with argon or air to $P_{\mathrm{a}}$ (see Equation 2). Thus, there appear to be only two unknowns ( $n_{\mathrm{g}}$ and $P_{v}$ ) in Equations G-5 and G-6, and they can be solved simultaneously to produce Equations 5 and 6.

However, if $P_{v}$ actually varies during the TV method, then an error is introduced into Equations 5 and 6 . Let $P_{v}=P_{H 2 O}+P_{v i}$ where $P_{v i}$ is the vapor pressure of ammonia in either volume State $1\left(V_{x}\right)$ or State $2\left(V_{x}+V_{2}\right)$; 1et $P_{v 1}=f * P_{v 2}$, and redetermine Equations 5 and 6 as

$$
n_{g}=\left[P_{e x L}-P_{2}-(f-1) P_{v z}\right]\left(\frac{V_{x}}{V_{z}}\right)\left[\frac{V_{x}+V_{2}}{R T}\right]
$$

and

$$
P_{\mathrm{v} 2}=P_{2}-\frac{n_{g} R T}{V_{E X L}-V_{S L}+V_{2}}-P_{H 2 O}
$$

where $V_{K}=V_{E X L}-V_{S L}$, and $P_{H 2 O}$ is the vapor pressure of water at temperature $T$.

\section{G.2.1 Insoluble Gas Quantity Error}

The fractional error (FE) in the insoluble gas quantity determination is defined as 


$$
F E=\frac{n_{g 5}-n_{g F 7}}{n_{g F 7}}=\frac{n_{g 5}}{n_{g F 7}}-1
$$

where $n_{95}$ is the insoluble gas quantity determined from Equation 5 , and $n_{g F 7}$ is the "actual" gas quantity based on Equation G-7. Then

$$
F E=\frac{(f-1) P_{v 2}}{\left[P_{e x L}-P_{2}-(f-1) P_{v 2}\right]}
$$

Thus, the error in TV measured gas quantity is small if ( $f-1$ ) $P_{v 2}$ is smaTl compared to $P_{\text {exL }}-P_{2}$. The $F E$ can be evaluated further by noting that $P_{\text {exL }}=P_{\text {ins }}+P_{H 2 O}+P_{y 1}$ and $P_{2}=P_{\text {ins } 2}+P_{H 2 O}+P_{v 2}$ where insoluble gas pressures are given by $P_{i n s}$ and $P_{\text {ins2 } 2}$, and are related by $P_{\text {ins }} / P_{\text {ins2 }}=\left(V_{x}+V_{2}\right) / V_{x}$. Subtracting $P_{2}$ from $P_{e x L}$ then yields

$$
P_{e x L}-P_{2}=\left(1-\frac{V_{x}}{V_{x}+V_{2}}\right) P_{i n s}+P_{v 1}-P_{\mathrm{v} 2}
$$

Assume that the ammonia vapor pressure initially in the extractor constitutes a fraction $(g)$ of the total gas pressure (excluding water vapor), such that $P_{v 1}=g *\left(P_{i n s}+P_{v 1}\right)$. Then

$$
P_{e x L}-P_{2}=\left[\left(1-\frac{V_{x}}{V_{x}+V_{2}}\right)\left(\frac{1}{g}-1\right) f+(f-1)\right] P_{v 2}
$$

Substituting Equation G-12 into Equation G-10 gives the relationship for the fractional error as

$$
F E=\frac{f-1}{\left[\left(1-\frac{V_{x}}{V_{x}+V_{2}}\right)\left(\frac{1}{g}-1\right) f\right]}
$$


As an example, for waste gas consisting of 5 percent ammonia (excluding water vapor), $g=0.05$ and assuming the worst case value of $f=1.26$, then $\mathrm{FE}=0.0527$ for a 5.3 percent error in insoluble gas quantity. Coincidentally, assuming the worst case values for $f$ previously described for a full or empty sampler results in $\mathrm{FE} \approx \mathrm{g}$. However, if $\mathrm{H} / \mathrm{m}_{\mathrm{L}}=2.2 \times 10^{6}$ $\mathrm{Pa} / \mathrm{mole}$ giving $\mathrm{f}=1.13$, then for $\mathrm{g}=0.05$, $\mathrm{FE}=0.029$, or a 2.9 percent error in $\mathrm{n}_{95}$.

Thus, the gas quantity error resulting from the approximation of constant $P_{v}$ during the TV expansion in volume (from the extractor to include the 2nd Volume) is manageable, particularly for samples with lower percentages of ammonia gas in the waste gas total.

\section{G.2.2 Ammonia Vapor Pressure Error}

The ammonia vapor pressure fractional error (PFE) due to the variation of ammonia pressure between the two measurement states when using Equation G-8 is defined as

$$
P F E=\frac{P_{\mathrm{v} 25}-P_{\mathrm{v} 2}}{P_{\mathrm{v} 2}}=\frac{P_{\mathrm{v} 25}}{P_{\mathrm{v} 2}}-1
$$

where $P_{v 25}$ is the ammonia vapor pressure in the second volume state $\left(V_{x}+V_{2}\right)$ calculated from Equation G-8 using $n_{g 5}$, and $P_{v 2}$ is the actual ammonia vapor pressure. Then

$$
P F E=\left[P_{2}-\left(P_{e x L}-P_{2}\right) \frac{V_{x}}{V_{2}}-P_{H 2 O}\right] \frac{1}{P_{v 2}}-1
$$

resulting in

$$
P F E=\left[\left(1+\frac{V_{x}}{V_{2}}\right)\left(P_{i n s 2}+P_{v 2}\right)-\left(P_{i n s}+P_{v 1}\right) \frac{V_{x}}{V_{2}}\right] \frac{1}{P_{v 2}}-1
$$

and finally

$$
P F E=(1-f) \frac{V_{x}}{V_{z}}
$$


Thus, in the worst case condition of $f=1.26$ and a nearly full sampler $\left(V_{x}=1235 \mathrm{~mL}\right)$, PFE $=-1.00$, for a 100 percent error in the determination of the ammonia vapor pressure.

Clearly, the potentially large error in measured ammonia vapor pressure using the Two Volume method suggests that greater reliance will need to be placed on the Hg Pump method for this particular parameter.

It should be noted that $f$ can be determined from a rearrangement of Equation G-17 if the $\mathrm{Hg}$ Pump method provides a reliable value for the ammonia vapor pressure $\left(\mathrm{P}_{\mathrm{v} 2}\right)$ and there are no other soluble gases present in significant quantity. A determination of the value of $f$ would be key to characterizing the ammonia properties in a given sample. Also, if the ASA method for determining ammonia concentration can be made to work properly, then a comparison between the ASA and the $\mathrm{Hg}$ Pump values for ammonia vapor pressure would provide increased confidence in the value determined for $f$. 


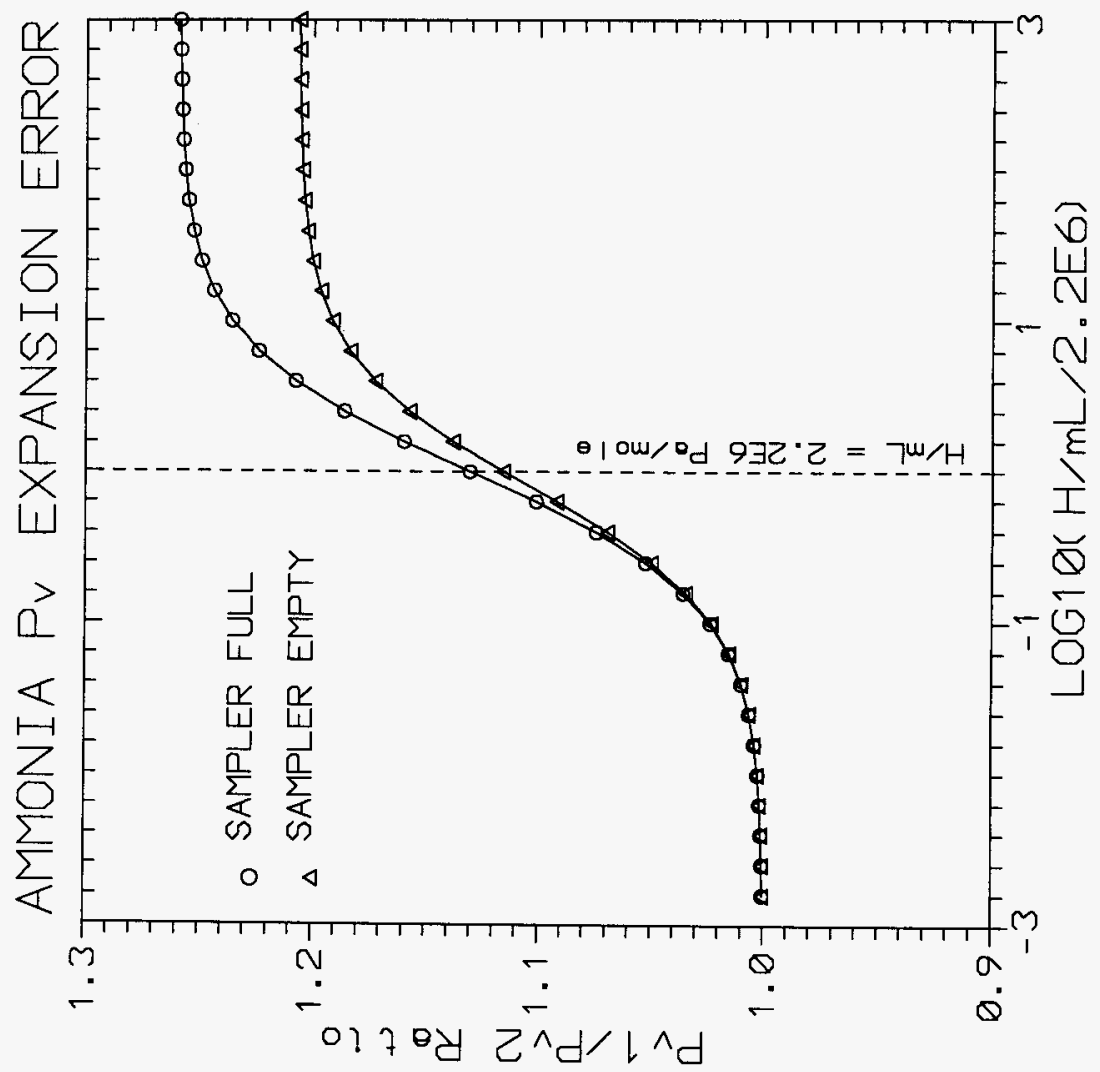

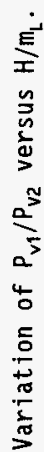




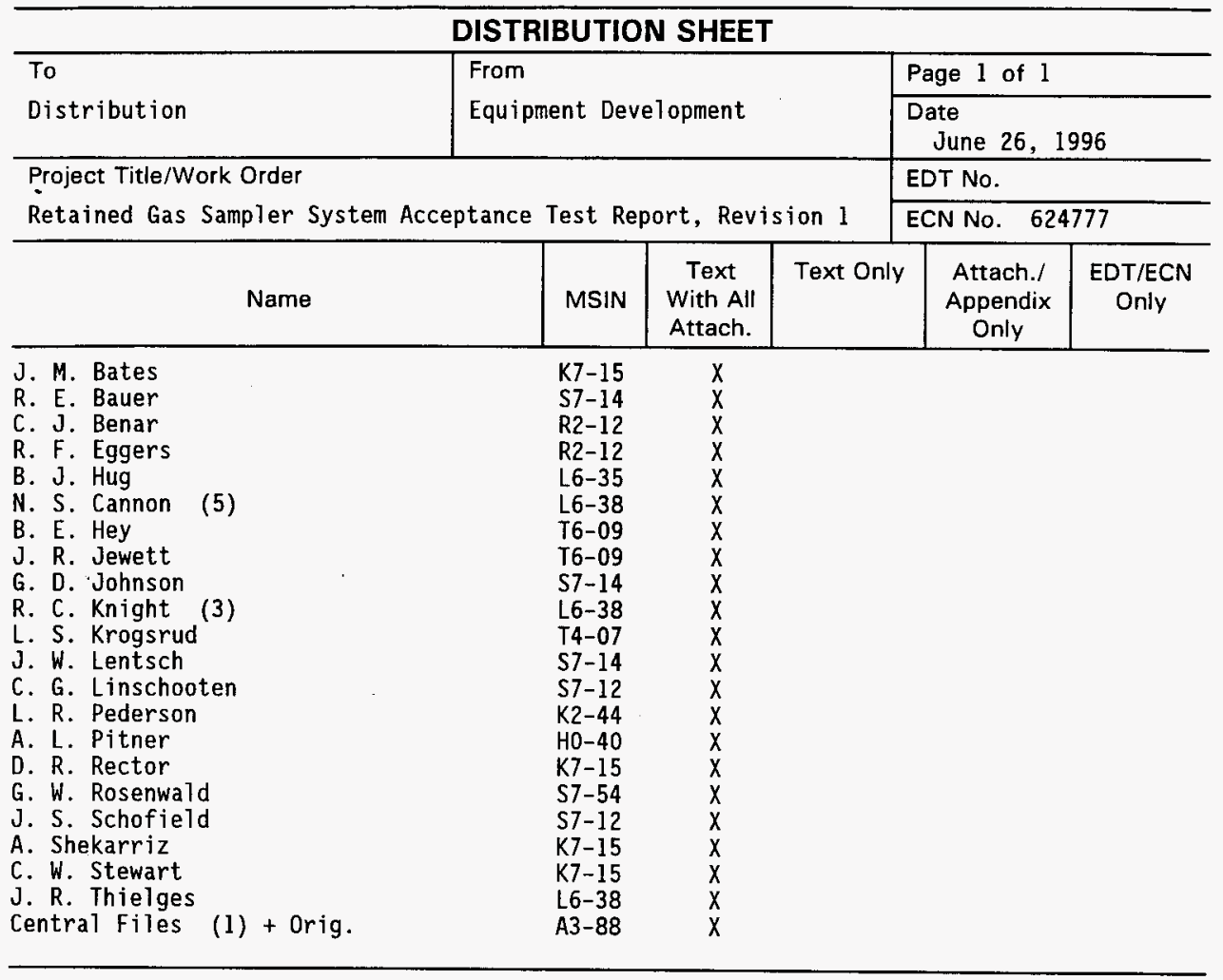

